NBER WORKING PAPER SERIES

WHY DID BANK STOCKS CRASH DURING COVID-19?

\author{
Viral V. Acharya \\ Robert F. Engle III \\ Sascha Steffen \\ Working Paper 28559 \\ http://www.nber.org/papers/w28559 \\ NATIONAL BUREAU OF ECONOMIC RESEARCH \\ 1050 Massachusetts Avenue \\ Cambridge, MA 02138 \\ March 2021
}

We thank Jennie Bai, Tobias Berg, Allen Berger, Christa Bouwman, Olivier Darmouni, Darrel Duffie, Max Jager, Rafael Repullo, Phil Strahan, Daniel Streitz, Anjan Thakor, Josef Zechner and participants at the 2020 Federal Reserve Stress Testing Conference and seminar participants at the Annual Columbia SIPA/BPI Bank Regulation Research Conference, Banco de Portugal, Bank of England, CAF, Federal Reserve Bank of Cleveland, NYU Stern Finance, RIDGE Workshop on Financial Stability, University of Southern Denmark, University of Durham, Villanova Webinars in Financial Intermediation, the Volatility and Risk Institute, World Bank, WU Vienna, for comments and suggestions and Sophie-Dorothee Rothermund and Christian Schmidt for excellent research assistance. The views expressed herein are those of the authors and do not necessarily reflect the views of the National Bureau of Economic Research.

NBER working papers are circulated for discussion and comment purposes. They have not been peer-reviewed or been subject to the review by the NBER Board of Directors that accompanies official NBER publications.

(C) 2021 by Viral V. Acharya, Robert F. Engle III, and Sascha Steffen. All rights reserved. Short sections of text, not to exceed two paragraphs, may be quoted without explicit permission provided that full credit, including $\odot$ notice, is given to the source. 
Why Did Bank Stocks Crash During COVID-19?

Viral V. Acharya, Robert F. Engle III, and Sascha Steffen

NBER Working Paper No. 28559

March 2021

JEL No. G01,G21

\begin{abstract}
$\underline{\text { ABSTRACT }}$
We study the crash of bank stock prices during the COVID-19 pandemic. We find evidence consistent with a "credit line drawdown channel". Stock prices of banks with large ex-ante exposures to undrawn credit lines as well as large ex-post gross drawdowns decline more. The effect is attenuated for banks with higher capital buffers. These banks reduce term loan lending, even after policy measures were implemented. We conclude that bank provision of credit lines appears akin to writing deep out-of-the-money put options on aggregate risk; we show how the resulting contingent leverage and stock return exposure can be incorporated tractably into bank capital stress tests.

Viral V. Acharya

Stern School of Business

New York University

44 West 4th Street, Suite 9-65

New York, NY 10012

and CEPR

and also NBER

vacharya@stern.nyu.edu

Robert F. Engle III

Department of Finance, Stern School of Business

New York University, Salomon Center

44 West 4th Street, Suite 9-160

New York, NY 10012-1126

and NBER

rengle@stern.nyu.edu

Sascha Steffen

Frankfurt School of Finance \& Management

Adickesallee 32-34

60322 Frankfurt

Germany

s.steffen@fs.de
\end{abstract}




\section{Introduction}

This paper investigates the crash of bank stocks during the COVID-19 pandemic and studies its causes, consequences and policy implications.

The pandemic and subsequent government-imposed lockdowns put the liquidityinsurance function of banks for the U.S. economy to a real-life test, as firms' cash flows dropped as much as $100 \%$, while operating and financial leverage remained sticky. As a consequence, U.S. firms with pre-arranged credit lines from banks drew down their undrawn facilities at a far greater intensity than in past recessions. Panel A of Figure 1 shows a sharp acceleration of credit-line drawdowns of publicly listed U.S. firms since March 1, 2020. ${ }^{1}$ Within three weeks, public firms drew down more than USD 300bn, with drawdowns particularly concentrated among riskier BBB-rated and non-investment-grade firms. ${ }^{2}$ Recent data shows that firms benefited from having access to credit lines during the pandemic when capital market funding froze (e.g., Acharya and Steffen, 2020a; Chodorow-Reich et al., 2020; Greenwald et al., 2020). Banks, however, faced unprecedented aggregate demand for credit-line drawdowns when the pandemic broke out at the beginning of March 2020. Since then, banks' share prices have persistently underperformed those of non-financial firms (Panel B of Figure 1). ${ }^{3}$

[Figure 1 about here]

We construct a new measure of the balance-sheet liquidity risk of banks defined as undrawn commitments plus wholesale finance minus cash or cash equivalents (all relative to

\footnotetext{
${ }^{1}$ Ford Motor Company was one of the largest U.S. firms to draw down its credit lines in March 2020, withdrawing USD 15.4bn (Appendix I shows the SEC filings). It was still BBB- rated by S\&P at this time. With USD 20bn in cash, credit lines make up a large part of its overall liquidity. Based on its loan contracts, Ford pays 15bps in commitment fees for any dollar-undrawn credit and 125bps once credit lines have been drawn down. Ford thus paid USD $23.1 \mathrm{mn}$ as long as the credit line was undrawn, and USD $192.5 \mathrm{mn}$ annually once the credit line was fully utilized. Importantly, once Ford was downgraded to non-investment grade, commitment fees increased to $25 \mathrm{bps}$ and credit spreads to $175 \mathrm{bps}$, an increase of $67 \%$ and $40 \%$, respectively.

${ }^{2} \mathrm{Li}$ et al. (2020) show - using call report data - that drawdowns amounted to more than USD 500bn, likely because of private firms, even further increasing the pressure on bank balance sheets.

${ }^{3}$ Bank stock prices hardly recovered even after the monetary and fiscal measures (i.e., after 3/23/2020) until the end of Q2 2020. However, average stock returns increased about 17\% during this period (relative to a mean decline of $65 \%$ in the month before).
} 
assets). ${ }^{4}$ We show that our measure of the liquidity risk of banks is important to understand the decline of bank stock prices during the first phase of the pandemic, i.e. from 1/1/2020 until $3 / 23 / 2020$, before decisive monetary and fiscal support measures were introduced. During this phase of the pandemic, stock prices of banks with high balance-sheet liquidity risk underperformed relative to those of banks with low balance-sheet liquidity risk, controlling for market beta and key bank performance measures (capitalization, asset quality, profitability, liquidity and investments). ${ }^{5}$ A one-standard-deviation increase in liquidity risk decreased stock returns by about $5 \%$ during this period, or $7.4 \%$ of the unconditional mean return.

We also posit alternative explanations for the underperformance of bank stock prices such as real estate exposure, warehousing activities of dealer-banks, or the presence of large derivative portfolios. Several other bank exposures came under stress during the pandemic (e.g., to the retail, hotel and leisure sectors). Exposure to oil prices also emerged as an important risk that might have contributed to the crash of bank stocks. ${ }^{6}$ Moreover, bank exposures to retail credit line commitments and consumer loans were also at risk of losses when unemployment rates and furloughs rose. Using bank-loan-level exposure data to these sectors sourced from the Dealscan database, we show that these risk factors do significantly affect bank stock returns. These exposures, however, appear to be orthogonal to balance-sheet liquidity risk. Furthermore,

\footnotetext{
${ }^{4}$ We develop and use a comprehensive measure of liquidity risk because the relative importance of its components (unused C\&I commitments or wholesale funding) might change over time. For example, bank reliance on wholesale funding has continued to decline since the global financial crisis while unused C\&I loans have increased over 2017-2019.

${ }^{5}$ In contrast to bank capital, there is no consensus in the literature on how to measure liquidity, and those measures that have been used follow different concepts. For example, Deep and Schaefer (2004) use the difference between scaled liquid assets and liabilities, focusing on on-balance-sheet components of liquidity. Berger and Bouwman (2009) construct a comprehensive liquidity measure using on- and off-balance-sheet components. Both measures follow the concept of liquidity creation. Our measure focuses on liquidity risk, particularly during aggregate economic downturns, through credit lines and short-term wholesale funding. Bai et al. (2018) use on- and offbalance-sheet items to construct a measure of liquidity risk incorporating current market liquidity conditions. While their measure is more complex and reacts (contemporaneously) once market liquidity conditions deteriorate, our measure is a relatively simple (ex-ante) measure of bank exposure to liquidity risk. We compare our measure to both previous measures, highlighting similarities and differences in section 8 of this paper.

${ }^{6}$ The energy sector was severely hit when on March 9, 2020 oil prices dropped by more than $20 \%$ on a single day. Both Saudi Arabia and Russia, two of the world's largest oil producers, decided to increase their oil output considerably having failed to reach an agreement with OPEC on possible production cuts. After this oil price shock, oil price volatility increased by more than six times (to more than $100 \%$ on an annualized basis) and energy stocks crashed. Banks are heavily exposed through loans provided to this sector.
} 
when we include measures of a bank's capital shortfall conditional on a severe market correction (for example, SRISK $^{7}$, which relies in turn on LRMES, a measure of stock returns conditional on market downturns), but do not take into account the role of undrawn credit lines, the explanatory power for bank stock returns remains unaffected.

To summarize, while other factors are important in understanding the performance of bank stock prices at the beginning of the pandemic, the aggregate drawdown risk associated with bank credit lines does not appear to be captured in traditional measures of bank exposure or systemic risk. That is, a bank's "contingent leverage" associated with aggregate drawdowns is akin to a deep out-of-the-money put option that is neither captured by a bank's stock beta nor by its (long-run) marginal expected shortfall (MES), or is possibly captured only ex-post, i.e. with a lag, as the event causing aggregate drawdowns unfolds.

We then show that this cross-sectional explanatory power of balance-sheet liquidity risk for bank stock returns is episodic in nature. Using separate cross-sectional regressions during the months of January 2020, February 2020 and during the 3/1/2020 to 3/23/2020 period, we show that liquidity risk explains stock returns only during the last period, when firms' liquidity demand through credit line drawdowns becomes highly correlated, but not before. We then employ time-series tests for bank stock returns to shed further light on this result. Interacting our bank-level liquidity risk measure with the aggregate measure of realized cumulative credit line drawdowns, we show that (daily) bank stock returns are significantly lower when aggregate drawdowns in the economy increase and banks have more balance-sheet liquidity risk. Further, stock returns for banks with greater liquidity risk are lower, particularly when drawdowns of riskier firms accelerate. Finally, these effects reverse only after monetary policy and fiscal policy measures. There is a reversal of undrawn C\&I credit lines on banks' balance sheets in Q2 and Q3 2020, but not to pre-COVID-19 levels. Consistently, we find that the episodic

\footnotetext{
${ }^{7}$ See NYU Stern Volatility \& Risk Institute, https://vlab.stern.nyu.edu/welcome/srisk, Acharya et al. (2016) and Brownlees and Engle (2017) for definition and estimation of LRMES and SRISK.
} 
explanatory power of balance-sheet liquidity risk for bank stock returns also reverses following policy measures. ${ }^{8}$

We confirm that the episodic co-movement of stock returns and the balance-sheet liquidity risk of banks is not specific to aggregate drawdown risk during the pandemic, but was also a feature of the global financial crisis (GFC) during 2007 to 2009. We use the same crosssectional tests as before and run them quarterly over the Q1 2007 to Q1 2009 period. We show that liquidity risk for banks ignited in Q3 2007, i.e., in the first phase of the GFC when the Asset Backed Commercial Paper (ABCP) market froze, as documented in Acharya et al. (2013). Liquidity risk remained priced in the cross-section of bank stock returns (even increased in economic magnitude) until the end of Q2 2008. The Federal Reserve and the U.S. government responded to the economic fallout of the Lehman Brothers default with a variety of measures to support the banking sector, following which we do not see any effect of liquidity risk on bank stock returns. Acharya and Mora (2015) show that banks had deposit shortfalls relative to credit line drawdowns during the GFC, unlike during the pandemic. In other words, the episodic nature of liquidity risk contributing to bank stock returns during the pandemic finds similar undertones during the GFC; the former caused by aggregate drawdown risk (credit lines) and the latter by aggregate rollover risk (wholesale finance). Our liquidity risk measure for banks spans both of these risks.

Next, we examine the reasons why bank stock prices were particularly sensitive to undrawn C\&I credit lines when the pandemic broke out. Does funding liquidity to source new loans become a binding constraint for banks as deposit funding does not keep pace with credit line drawdowns (the "funding channel")? Or, does the drawdown of credit lines lock up bank capital against term loans and impair bank loan origination, preventing banks from making

\footnotetext{
${ }^{8}$ Interestingly, the Fed already conducted large interventions in the repo market on 3/12/2020. The OIS-spread, a measure for liquidity conditions in financial markets, reverted already following these interventions. They were, however, insufficient to stop the further decline of bank stock prices suggesting that liquidity was not the binding constraint for banks at the beginning of the COVID-19 pandemic.
} 
possibly more profitable loans (the "capital channel")?” To distinguish between these channels, we construct two proxies: (1) Gross drawdowns as the percentage change in credit line drawdowns; and (2) Net drawdowns as the percentage change in drawdowns minus the change in deposit funding. Holding gross drawdowns fixed, our measure of net drawdowns helps us understand the importance of changes in bank deposits for bank stock returns. We find that while bank stock returns during $1 / 1 / 2020$ to $3 / 23 / 2020$ are particularly sensitive to gross drawdowns, they do not load significantly on net drawdowns. Importantly, a higher level of bank capital buffer attenuates the negative effect of gross drawdowns on stock returns. These results suggest that at the onset of the pandemic bank capital and not bank liquidity appears to have been perceived as the binding constraint causing liquidity risk to adversely affect bank stock returns. In this regard, the pandemic fallout for banks differs from that during the GFC when banks struggled on the liquidity front to meet drawdowns (Acharya and Mora, 2015).

The development of credits spreads at the beginning of the pandemic suggests that this phenomenon might have also affected loan market originations. We plot the time-series of credit spreads in the loan and bond market over the Q1 2019 to Q3 2020 period in Figure 2. In particular, we plot the loan-bond differential (Panel A of Figure 2) and find that that difference between loan and bond spreads increased from about $2.5 \%$ to $3.5 \%$ following the outbreak of COVID-19 and remained highly elevated, particularly driven by loans to riskier firms (Panel B of Figure 2). Bond spreads, however, reverted back almost to pre-COVID levels (not shown). This is consistent with the interpretation that bank health was materially affected by the

\footnotetext{
${ }^{9}$ For the banks that provided credit lines to Ford Motors (as described in our introductory example in footnote 1 above), these commitments were (in aggregate) a USD 15.4bn off-balance-sheet C\&I loan commitment as of $12 / 31 / 2019$. The capital treatment of their commitment depends on whether banks follow the standardized (SA) or internal ratings-based (IRB) approach for credit risk. Under Basel III, the standardized approach differentiates between irrevocable and revocable commitments. Revocable commitments carry a credit conversion factor (CCF) of $10 \%$ and irrevocable commitments (with a maturity of more than 12 months) a CCF of 50\%. Assuming an $8 \%$ capital requirement, an undrawn credit line thus requires funding in the range of $0.8 \%$ to $4 \%$ for banks using the SA. For IRB banks - as applies to most of our sample banks - the CCF might be considerably lower (Behn et al., 2016). In other words, a bank might need to fund $90 \%$ or more of the required capital when a credit line is drawn down and becomes a balance-sheet loan, which adversely impacts other business activities, particularly in an aggregate downturn.
} 
pandemic, and not just temporarily, impacting the access of firms to bank loans as well as the cost of bank credit. ${ }^{10}$

[Figure 2]

Investigating new loan originations, we find that banks with large credit-line drawdowns indeed significantly reduced their supply of newly issued loans. ${ }^{11}$ We use a Khwaja and Mian (2008) estimator and aggregate our data at a borrower $\mathrm{x}$ bank $\mathrm{x}$ loan type $\mathrm{x}$ month level, collapse the sample into a pre- and post-COVID-19 period (where "post" is the period after 4/1/2020), and saturate the estimation with borrower $\mathrm{x}$ bank $\mathrm{x}$ loan type fixed effects. We show that both the number of loans as well as loan amounts are lower for banks with both higher gross and net drawdowns after the breakout of the COVID-19 pandemic. Importantly, when we estimate separately the effect on term loans and credit lines (using borrower $\mathrm{x}$ bank fixed effects), term loan originations are substantially lower for banks with higher gross drawdowns, whereas new credit line commitments decrease mainly for banks with higher net drawdowns. This confirms that gross drawdowns reduce the capital available to banks and thus term lending, whereas banks experiencing net drawdowns are reluctant to take on additional liquidity risk, but they can issue term loans as long as they have capital to provide for them. Overall, there appear to be long-term real consequences because of banks' contingent leverage materializing from a drawdown of credit lines during an aggregate shock.

A final key question is how can policy makers address aggregate drawdown risk in an ex-ante manner? One possible way is for regulators to add the effect of drawdowns to stress tests and require banks to fund these exposures with equity. ${ }^{12}$ In our last step, we therefore

\footnotetext{
${ }^{10}$ The Senior Loan Officer Survey of the Federal Reserve also shows that at the end of Q3 2020, about 75\% of loan officer reported a tightening of bank lending standards for small and medium/large firms.

${ }^{11}$ The theoretical literature argues that a key function of bank capital is to absorb risk, i.e., more capital facilitates bank lending. Bhattacharya and Thakor (1993), Repullo (2004), von Thadden (2004), and Coval and Thakor (2005), among others, argue that capital increases risk-bearing capacity. Allen and Santomero (1998) and Allen and Gale (2004) show that banks with less capital might have to dispose of illiquid assets when facing an adverse shock.

${ }^{12}$ We find that banks do not account for aggregate drawdown risk in fees or spreads when initiating new loan contracts. Moreover, drawdowns do also not appear to be constrained through covenants. We investigate all loan amendments during the post-COVID period and find that not a single loan amendment was initiated through a
} 
quantify the capital shortfall that arises due to banks' balance-sheet liquidity risk and show how it can be incorporated tractably into bank stress tests. Acharya et al. (2012), Acharya et al. (2016) and Brownlees and Engle (2017) developed the concept of SRISK, a measure of the capital shortfall of a stressed aggregate market correction (e.g., 40\% decline in the S\&P 500 index), measured relative to an $8 \%$ requirement in terms of market value of equity to debt plus market value of equity. This measure, however, does not account for the impact of credit lines, which are off-balance-sheet or contingent liabilities. Given our results, such an impact can be broken down into two components. First, contingent liabilities enter banks' balance sheets as realized liabilities during periods of stress. Using drawdown data during the COVID crisis, the GFC and the 2000-2003 recession, we extrapolate the expected drawdown in a stress scenario with a $40 \%$ market correction based on each of these three stressed periods. We find the expected (incremental) drawdown rates in such a stress scenario to be in the range $11 \%$ to $23 \%$. Using these expected drawdown rates, we calculate the additional equity capital that would be required to maintain adequacy against higher realized liabilities in periods of stress. Second, we have to account for the negative episodic effect of liquidity risk on bank stock prices during periods of stress. Using the loadings from our cross-sectional regressions of bank stock returns on balance-sheet liquidity risk during the COVID-19 crisis, we estimate the additional equity shortfall of banks based on their end of Q4 2019 market values of equity.

Summing both components, we show that the additional capital shortfall for the U.S. banking sector as a whole due to balance-sheet liquidity risk amounted to more than USD 270bn as of $12 / 31 / 2019$ in a stress scenario of a $40 \%$ correction to the global stock market with the top 10 banks contributing about USD 230bn. The incremental capital shortfall of the top 10 banks is about 1.5 times larger than the capital shortfall estimate without accounting for contingent liabilities.

covenant violation. On the contrary, banks and firms regularly negotiated a covenant relief period early in the pandemic. In other words, contractual mechanisms also did not attenuate aggregate drawdowns at the start of the pandemic. 
The paper proceeds as follows. We first describe the related literature. In Section 3, we present the data. In Section 4, we describe our measure of balance-sheet liquidity risk and investigate the effect of liquidity risk on bank stock returns. We investigate the liquidity measure's components in Section 5. Section 6 analyzes the funding vis-à-vis the capital channel and also studies the consequences for the real economy. Section 7 illustrates how to incorporate episodic liquidity risk of bank balance sheets in stress tests and assess capital shortfalls. We provide a discussion of our results in section 8. Section 9 concludes.

\section{Related literature}

Our paper relates to the literature highlighting the role of banks as liquidity providers. Kashyap et al. (2002) proposed a risk-management motive to understand the unique role of banks as liquidity providers to both households and firms. As long as demand for deposits and loans is not too highly correlated, banks can pool both types of customers and hold less (costly) liquid assets. Gatev and Strahan (2006) build this idea and argue that banks can insure firms even against systematic declines in liquidity because of deposit inflows during crises. Ivashina and Scharfstein (2010) provide evidence of an acceleration of credit-line drawdowns during the 2007-2009 crisis as well as an increase in deposits. Acharya and Mora (2015) show that during the 2007-2009 crisis - in which the banking system itself was at the center of the crisis - banks faced a crisis as liquidity providers and could only perform this role because of significant support from the government. Li et al. (2020) show that during the COVID-19 crisis, aggregate deposit inflows were sufficient to fund the increase in liquidity demand. Acharya and Steffen (2020b) use simulations based on drawdown scenarios from prior crises and arrive at similar conclusions. Kapan and Minoiu (2020) show that banks exposed to larger credit-line drawdowns reduce lending. None of these papers, however, explores the implications of banks as liquidity providers for bank stock returns when drawdowns affect bank capital availability for other intermediation functions, and especially when the realized risk is aggregate in nature. 
There is a growing literature on the implications of COVID-19 for corporate finance, and the use of credit lines in particular. Chodorow-Reich et al. (2020) show that drawdowns of credit lines came exclusively from large firms during the first phase of the pandemic and document that banks did not honor commitments to smaller firms. Greenwald et al. (2020) also show that particularly large firms used their credit lines and banks with larger drawdowns reduced term lending to small firms more relative to other banks. Darmouni and Siani (2020) show that a large percentage of credit lines were repaid through bond issuances in Q2 and Q3 2020. By examining both gross drawdowns and net (of deposit inflows) drawdowns, we demonstrate that credit-line drawdowns reduce banks' franchise value because of binding capital constraints. While banks with higher gross drawdowns reduce term lending, banks with higher net drawdowns reduce credit line originations. ${ }^{13}$

Other papers consider stock price reactions to the COVID-19 pandemic, emphasizing the importance of financial policies (Ramelli and Wagner forthcoming), financial constraints and the cash needs of affected firms (Fahlenbrach, Rageth, and Stulz 2020), changing discount rates because of higher uncertainty (Gormsen and Koijen 2020, Landier and Thesmar 2020), and social-distancing measures (Pagano, Wagner and Zechner 2020). These papers focus on stock prices of non-financial firms, not banks. Demirguc-Kunt et al. (2020) investigate the bank stock market response to the COVID-19 pandemic and policy responses globally. They highlight that the effectiveness of policy measures was dependent on bank capitalization and fiscal space in the respective country. We focus instead on the implications of credit line drawdowns for bank stock returns and the consequences for bank lending.

\footnotetext{
${ }^{13}$ Other papers explore the determinants of credit-line drawdowns in previous crises. Ivashina and Scharfstein (2010) document an acceleration of credit line drawdowns during the 2007-2009 crisis; their evidence is consistent with ours. Berg et al. (2016) show that credit lines are more likely to be used if a borrower's economic performance deteriorates, particularly for non-IG and unrated firms. Berg et al. (2017) show that U.S. firms' drawdown behavior is particularly sensitive to the overall market return. We show that pandemic drawdowns have been more intense but similar in spirit.
} 
Our paper also contributes methodologically to the literature on bank stress tests. After the 2007-2009 crisis, a variety of measures were developed to quantify the systemic risk of the banking sector. In addition to the SRISK measure of Acharya et al. (2012), Acharya et al. (2016) and Brownlees and Engle (2017), which we discussed in the introduction, Adrian and Brunnermeier (2015) develop the concept "CoVaR", which measures the risk to the financial system conditional on a bank being in distress. These measures, however, do not look at the role of contingent liabilities of banks or their episodic impact on bank returns; we show how these important considerations can be embedded into bank stress tests.

\section{Data}

We collect data for all publicly listed bank-holding companies of commercial banks in the U.S. To construct or main dataset, we follow Acharya and Mora (2015) and drop all banks with total assets below USD 100mn at the end of 2019 and also only keep those banks that we can match to the CRSP/Compustat database. All financial variables (on the holding-company level) are obtained from the call reports (FR-Y9C) and augmented with data sourced from SNL Financial. We keep only those banks for which we have all data available for our main specifications during the COVID-19 pandemic, which limits our sample to 127 U.S. bank-holding companies (accounting for about $80 \%$ of all outstanding credit lines). ${ }^{14}$ All variables are explained below or in Appendix II.

We obtain daily stock returns for our sample banks from CRSP. We manually match these banks to the Thomson Reuter Dealscan database to obtain loan-level exposure data for the banks in our data set. For some tests and statistics, we use secondary market data about different industry sectors (e.g., the oil or retail sector) from Refinitiv. We obtain information

\footnotetext{
${ }^{14}$ Berger and Bouwman (2009), among others, document that off-balance-sheet credit commitments are important for large banks, but not medium-sized and small banks. The smaller number of banks in our dataset is a consequence of changes in reporting requirements over time (i.e. an increase in the size threshold above which banks have to provide specific information).
} 
about a bank's systemic risk from the Volatility and Risk Institute at NYU Stern. Other market information is downloaded from Bloomberg (e.g. oil volatility (CVOX), VIX, S\&P 500 market return).

\section{Can balance-sheet liquidity risk explain bank stock returns?}

\subsection{Balance-sheet liquidity risk of banks}

To construct our measure of balance-sheet liquidity risk, we collect bank balance sheet information as of Q4 2019 from call reports and construct three key variables associated with bank liquidity risk following Acharya and Mora (2015): (1) Unused Commitments: The sum of credit lines secured by 1-4 family homes, secured and unsecured commercial real estate credit lines, commitments related to securities underwriting, commercial letter of credit, and other credit lines (which includes commitments to extend credit through overdraft facilities or commercial lines of credit); (2) Wholesale Funding: The sum of large time deposits, deposits booked in foreign offices, subordinated debt and debentures, gross federal funds purchased, repos, and other borrowed money; (3) Liquidity: The sum of cash, federal funds sold and reverse repos, and securities excluding MBS/ABS securities. All variables are defined in Appendix II.

We construct a comprehensive measure of bank balance-sheet liquidity risk (Liquidity Risk):

$$
\text { Liquidity Risk }=\frac{\text { Unused Commitments }+ \text { Wholesale Funding }- \text { Liquidity }}{\text { Total Assets }}
$$

Figure 3 shows the time-series of the mean of Liquidity Risk (using our sample banks and weighted by total assets) quarterly since January 2010 as well as its components, i.e. Unused C\&I Credit Lines and Wholesale Funding, both relative to total assets.

[Figure 3 about here] 
Liquidity Risk has decreased since Q1 2010 to a level of about 20\% relative to total assets (Panel A of Figure 3). In 2017, Liquidity Risk started to increase until Q4 2019, i.e. before the start of the COVID-19 pandemic. At the beginning of the pandemic in Q1 2020, liquidity risk dropped about 40\% and continued to decline somewhat in Q2 and Q3 of 2020.

Panel B of Figure 3 shows the components. The decrease is driven by the declining share of wholesale funding relative to total assets that accelerated during the COVID-19 pandemic. Since 2017, the marginal increase in the importance of unused C\&I loans has been larger than the marginal decline in wholesale funding exposure and Liquidity Risk started to increase again. The large decline of Liquidity Risk during the first quarter in 2020 was driven by the decrease in unused C\&I credit lines consistent with the increase in drawdowns documented in Figure 1 above. We saw an immediate reversal of Unused C\&I Credit Lines in Q2 and Q3 2020; however, not to pre-COVID-19 levels, pointing to a partial repayment of credit lines by U.S. firms. In Online Appendix B, we show that particularly non-investment grade rated firms did not repay their credit lines, likely as they only gradually regained access to capital markets as documented by Acharya and Steffen (2020). Banks experience only limited capital relief when high-quality firms repay their credit lines, with possible implications for their lending and investment activities. We investigate the importance of unused C\&I credit lines for the stock price crash of U.S. banks as well as their lending activities further in this paper.

\subsection{Methodology}

To show that balance-sheet liquidity risk is priced in the cross-section of bank stock returns, we run the following ordinary-least-squares (OLS) regressions:

$$
r_{i}=\alpha+\gamma \text { LiquidityRisk }_{i}+\sum \beta X_{i}+\varepsilon_{i}
$$


We compute daily excess returns $\left(r_{i}\right)$, which we define as the log of one plus the total return on a stock minus the risk-free rate defined as the one-month daily Treasury bill rate. $X$ is a vector of control variables (e.g., bank balance-sheet characteristics) that have been shown to affect bank stock returns. All control variables are measured at the end of 2019 and capture key bank performance measures (capitalization, asset quality, profitability, liquidity and investments) that prior literature has shown to be important determinants of bank stock returns (e.g., Fahlenbrach et al., 2012; Beltratti and Stulz, 2012). More specifically, these variables include among others: a bank's Equity Beta, constructed using monthly data over the 2015 to 2019 period and the S\&P 500 as market index, the natural logarithm of total assets (Log(Assets)), the non-performing loans to loan ratio (NPL/Loans), the equity-asset-ratio (Equity Ratio), NonInterest Income ${ }^{15}$, return-on-assets $(R O A)$ and the deposit-loan-ratio (Deposits). All variables are described in detail in Appendix II and are shown in the regression specifications in the sections below. Standard errors in all cross-sectional regressions are heteroscedasticity robust.

\subsection{Descriptive evidence}

We first investigate graphically whether differences in ex-ante liquidity risk across banks can explain their stock price development since the outbreak of COVID-19. We classify banks into two categories, with high or low balance-sheet liquidity risk using a median split of our Liquidity Risk variable. We then create a stock index for each subsample of banks indexed at 1/2/2020 using the (market-value weighted) average stock returns of banks in each sample. The difference between both subsamples is shown in Panel A of Figure 4. Bank stock prices collapsed as the COVID-19 pandemic started at the beginning of March 2020. Consistent with the idea that liquidity risk explains bank stock return, we find that banks with higher liquidity risk perform worse than other banks. In Panel B of Figure 4, we show bank stock returns on our measure of Liquidity Risk. The regression line through the scatter plot has a negative (and

\footnotetext{
${ }^{15}$ Demsetz and Strahan (1997) use non-interest income to net interest income ratio as a measure how bank holding companies rely on off-balance sheet activities more broadly (e.g. through derivatives contracts).
} 
statistically significant) slope. That is, banks with higher Liquidity Risk had lower stock returns in the cross-section of our sample banks.

[Figure 4 about here]

Panel A of Table 1 shows the stock returns of the firms in our sample for different periods, January 2020, February 2020 and the 3/1/2020 to 3/23/2020 period, and we calculate excess returns over these time periods. The average excess return is negative in all periods, ranging from $-7.9 \%$ in January 2020 to $-47.1 \%$ during the period 3/1/2020 to 3/23/2020 (and even $-67.5 \%$ from $1 / 1 / 2020$ to $3 / 23 / 2020$ ).

Panel B of Table 1 shows descriptive statistics of bank characteristics as of Q4 2019. In addition to the control variables used in our regression, we also provide summary statistics of Liquidity Risk and its components. All these risk measures appear to be economically relevant. For example, the average Liquidity Risk is 0.209 , the average bank has unused C\&I loan commitments of about $8.1 \%$ relative to total assets, and the average wholesale funding-assetratio is $13.2 \%$. The average bank has a beta of 1.2 measured against the S\&P 500 (i.e. it broadly resembles the U.S. economy) and a capitalization (equity-asset ratio) of $12 \%$. We have omitted a discussion of the other variables but include their summary statistics to facilitate the interpretation of our estimates in the coming sections.

[Table 1 about here]

\subsection{Multivariate results}

The estimation results for regression (1) are reported in Panel A of Table 2.

[Table 2 about here]

As a dependent variable we use bank stock returns measured as excess returns in $1 / 1 / 2020$ to $3 / 23 / 2020$, i.e. the first phase of the current COVID-19 pandemic and before the decisive fiscal and monetary interventions. In column (1), we only include Liquidity Risk and Equity Beta and show that banks with a higher ex-ante balance-sheet liquidity risk and (as expected) high beta have lower stock returns during this period. When we add the different 
control variables, the coefficient of Liquidity Risk becomes, if anything, economically stronger and the explanatory power of the regressions increases as well (by more than $50 \%$ from column 1 to column 5). Economically, a one standard deviation increase in Liquidity Risk reduces stock returns during this period by about $5 \%$. The other control variables behave as expected (focusing on those that turn out to have significant explanatory power): banks with more nonperforming loans (NPL/Loans), lower return-on-assets (ROA), lower Distance-to-Default and higher deposit ratios (Deposits/Assets) have lower stock returns during this period. ${ }^{16}$

A possible explanation for bank stock returns during this period could be a large exposure to the real estate sector (as measured using a Real Estate Beta), large warehouses as banks act as dealer banks (Current Primary Dealer Indicator) or larger derivative portfolios (Derivates/Assets). Our regressions show, however, that stock returns do not load significantly on these factors (columns 3 to 5) once the other control variables are accounted for.

Robustness tests. Panel B of Table 2 shows the results of our robustness tests. For example, it could be that those banks with high unused C\&I credit lines are also those with high retail credit card commitments. Given the potential stress in the retail sector due to e.g. lay-offs and furloughs, our Liquidity Risk measure might pick up these effects. We collected each bank's exposure (though we could not identify this clearly for one bank in our sample) to off-balancesheet credit card commitments and add this to our regression model (we use the model from column 5 of Panel A of Table 2). This variable does not enter significantly in our regression (column 1), more importantly, the coefficient on Liquidity Risk remains unchanged. Using onbalance-sheet Consumer Loans / Assets (column 2) does not change our results either.

Exposure to oil price risk is another important (macro) risk factor that might have also contributed to the crash of bank stocks. After the oil price shock on March 9, 2020, the market performance of the oil \& gas sector considerably deteriorated. ${ }^{17}$ Moreover, other sectors were

\footnotetext{
${ }^{16}$ Gatev and Strahan (2006) show that banks with large credit-line commitments are also high deposit banks.

17 We provide some descriptive evidence consistent with this in Online Appendix A. Figure A.1 shows the performance of the oil \& gas sector vis-à-vis other sectors directly affected by the pandemic (e.g., retail, leisure
} 
particularly impacted by the pandemic, e.g., the retail, leisure, and hotel \& gaming industry. Banks with large exposures to these sectors (through credit-line and also term loan exposures) might experience larger stock price declines. We evaluate a bank's exposure to the oil \& gas and other sectors using its loan exposures as of 12/31/2019. We obtain this data from Thomson Reuters LPC and allocate loan amounts among syndicate banks following the prior literature (e.g., Ivashina, 2009). We construct a new variable, Oil Exposure / Assets, which is the sum of a bank's active loan exposures to oil \& gas firms scaled by total assets. Similarly, we construct a similar measure of exposures to firms in the retail, leisure, and hotel \& gaming industry, add all these exposures and scale them by total assets (Other Sectoral Exposures / Assets).

We include both exposure variables in our regression (columns 3 and 4). Moreover, as all oil \& gas and sectoral exposures are based on loans reported in Dealscan and thus available only for a subset of banks, we include a dummy for those banks for which we could not find exposure data (unreported). The results show that banks with larger exposures to oil and the other sectors experienced lower stock returns during the first phase of the pandemic. Stock returns still load significantly on Liquidity Risk, but the economic magnitude is somewhat lower, which was expected given the smaller subset of banks for which exposure data is available. ${ }^{18}$

\section{Understanding balance-sheet liquidity risk of banks}

and hotel \& gaming) using returns from loans traded in the secondary market in these sectors. While the returns in the loan market declined substantially in all sectors, the loan return of oil \& gas and mining firms significantly underperformed the other sectors even after the announcement of the interventions by the Fed on March 23, 2020. Figure A. 2 shows the time-series of oil-price volatility using the CVOX oil price volatility index. While oil price volatility increases episodically during economic downturns (e.g., during the global financial crisis (GFC) of 2007 to 2009), the European sovereign debt crisis (2011-2012), and the oil \& gas crisis in 2015-2016), volatility increased by more than six times (to more than $100 \%$ on an annualized basis) around March 9, 2020 and energy stocks crashed.

${ }^{18}$ We also compute a bank's beta with respect to the oil and other sectors (based on Fama-French (FF) 49 industry portfolios) over the 12-month period prior to the pandemic and included these betas as proxy for bank exposures. E.g., the correlation between the beta with respect to the oil sector and banks' Dealscan exposure to the oil sector is about $50 \%$. Estimating regression (1) using the beta does not change the coefficient of Liquidity Risk. Interaction the exposure beta with the realized performance in March of the same FF industry portfolio does not change our results. 
Our previous results show that the liquidity risk of banks helps to explain bank stock returns during the first phase of COVID-19. The pandemic started in western economies at the beginning of March 2020; before then, firms had no problems accessing liquidity. But at the beginning of March 2020, it became a major concern for most firms (e.g., compare the increase in aggregate drawdowns in Figure 1 above). ${ }^{19}$ Does liquidity risk also become apparent as an explanatory risk factor when aggregate drawdown risk increased? Which components of Liquidity Risk matter and how important are undrawn C\&I credit lines relative to, e.g. wholesale funding, during the COVID-19 pandemic? Did the fiscal and monetary response help attenuate aggregate drawdown risk? And, is this pattern unique for the COVID-19 pandemic or do we observe the same dynamic repeatedly during episodes of aggregate drawdown risk? These are the questions we set out to address in this section.

\subsection{Does balance-sheet liquidity risk have an impact on bank stock returns?}

Panel A of Table 3 shows the estimation results from equation (1) separately for the three periods.

\section{[Table 3 about here]}

The coefficient estimates for January 2020 are shown in columns 1 to 2, for February 2020 in columns 3 to 4 and for the $3 / 1 / 2020$ to $3 / 23 / 2020$ period in column 5 to 6 , with and without the control variables described above. During the first two months in 2020, bank stock returns do not load significantly on liquidity risk. However, during the March 1 to March 23 period, it emerges as an important risk factor, i.e., banks with higher balance-sheet liquidity risk had significantly lower stock returns during this period. Also, the economic magnitude of the equity beta increases substantially during this stress period.

\footnotetext{
${ }^{19}$ Refinitiv surveyed banks as to the key risks (investment grade) corporate clients were concerned about in March 2020. The key risks mentioned include cash flow impact, availability and access to liquidity, and access to future capital, highlighting the aggregate demand for credit-line drawdowns at the beginning of the pandemic.
} 
Time-series evidence. Using time-series regressions, we show aggregate drawdowns can explain bank stock returns with high ex-ante exposure to Liquidity Risk during the 3/1/2020 to $3 / 23 / 2020$ period. We run the following time-series regression:

$$
r_{i, t}=\alpha+\gamma \text { LiquidityRisk }_{i} \times \text { Drawdowns }_{t}+\beta r_{S \& P, t}+\mu_{i}+\varepsilon_{i, t}
$$

We interact Liquidity Risk with the natural logarithm of the realized daily aggregate credit line drawdowns (Log(Cumulative Total Drawdowns)) and add the daily realized return of the S\&P 500 stock index $\left(r_{S \& P, t}\right)$ as well as a bank fixed effect $\left(\mu_{i}\right)$. We use Newey-West standard errors. The results are reported in Panel B of Table 3.

Column 1 shows total aggregate credit-line drawdowns. We aggregate credit-line drawdowns across BBB-rated firms (column 2, non-investment-grade rated firms (column 3) and unrated firms (column 4). ${ }^{20}$ Bank (daily) stock returns are significantly lower when aggregate drawdowns in the economy increase and banks have more balance-sheet liquidity risk. Stock returns for banks with greater liquidity risk are lower, particularly when drawdowns of riskier firms accelerate. Overall, both our cross-sectional and time-series tests suggest that bank balance-sheet liquidity risk can episodically explain bank stock returns, emerging in an aggregate downturn with an increase aggregate liquidity demand for credit lines.

\subsection{Components of liquidity risk and bank stock returns}

Figure 2 shows that Liquidity Risk decreased since the global financial crisis but has increased again since 2016. This increase is driven by a surge in unused C\&I credit lines, while wholesale funding (a major driver of liquidity risk during the GFC) continued to decrease relative to total assets. In the next step, we split Liquidity Risk into its components to investigate their differential impact on bank stock returns during the first phase of the pandemic. The results are

\footnotetext{
${ }^{20}$ Due to the high correlations between cumulative credit-line drawdowns across different rating classes, common variance inflator tests reject using them together in a single regression.
} 
reported in Table 4. We include all control variables described in model (5) in Panel A of Table 2.

[Table 4 about here]

We first include only Unused C\&I Loans / Assets (column 1), then add Liquidity / Assets (column 2) and then add Wholesale Funding / Assets (column 3) to the regression model. The results suggest that ex-ante balance-sheet liquidity risk of banks is driven by banks' exposure to unused C\&I loans. Bank stock returns load significantly on this factor while the coefficients on both wholesale funding and liquidity are economically small and statistically insignificant. In other words, banks' exposure to unused C\&I loans are key to understanding bank stock returns during the early stages of the pandemic.

In columns 4 and 5, we add oil exposure and other sectoral exposure to the hotel, leisure and retail industry (all scaled by total assets) to the regression model. All oil \& gas and sectoral exposures are based on loans reported in DealScan and thus are available only for a subset of banks. In column 6, we add SRISK/Assets as an additional control. These regressions include a dummy for banks for which we do not find exposure data or no SRISK (unreported). As before, banks with more exposure to the oil and other affected sectors as well as higher systemic risk have lower stock returns but the coefficient on Unused C\&I Loans / Assets does not change.

\subsection{Reversal of the effect of liquidity risk on bank stock prices}

Our previous tests show that liquidity risk explains bank stock returns during the first few weeks of the COVID-19 pandemic, i.e. before the monetary and fiscal response in the U.S. toward the end of March 2020. In a related paper, Acharya and Steffen (2020) show that capital market funding became immediately available after the Federal Reserve interventions on 3/23/2020, stopping the credit line drawdowns for all but the riskier firms as bond market access still eluded them. Aggregate demand for credit-line drawdowns attenuated after the interventions. Importantly, Figure 2 above suggests that high-quality firms have repaid credit lines, leading to 
a reversal of unused C\&I credit lines on bank balance sheets. We thus investigate whether we observe a similar reversal in bank stock prices following the Fed interventions in March 2020.

Panel A of Table 5 shows descriptive statistics of bank stock returns in April, May and June 2020 and during the $3 / 24 / 2020$ to $6 / 30 / 2020$ period. On average, the stock prices of our sample banks increased about $18 \%$ over the entire period, which is small given the mean drop of $67 \%$ during the $1 / 1 / 2020$ to $3 / 23 / 2020$ period. In other words, bank market capitalization has, on average, hardly improved during this period.

[Table 5 about here]

We show the results from regressions of bank stock return on Liquidity Risk and its components and all control variables used before in Panel B of Table 5. Columns 1 and 2 show the results for April and May 2020. While the coefficient of Liquidity Risk is positive, it does not significantly enter into the regression. The effects somewhat increase in June 2020 and become statistically significant (column 3) but are driven largely by banks with high ex-ante unused C\&I lines of credit (column 4). The results become less noisy when measuring stock returns over the $3 / 24 / 2020$ to $6 / 30 / 2020$ period and also become economically larger (columns 5 and 6). That is, stock prices of those banks that have experienced a large decline in stock price during the first weeks of the pandemic recover somewhat in the period after the Fed interventions. The control variables (not reported) show a similar reversal.

Taken together, our results so far show that liquidity risk episodically explains bank stock returns. Banks with high liquidity risk experience a stock price decline during the first phase of the COVID-19 pandemic, i.e. during a period of high aggregate liquidity demand for bank credit lines of firms, but not before. This relationship even reverses when capital market funding became available after policy stabilization measures were put in place.

\subsection{Balance-sheet liquidity risk of banks during the global financial crisis (2007-2009)}


Are these effects specific to the COVID-19 pandemic or did liquidity risk also episodically explain stock returns during other times of aggregate risk? To understand whether this effect occurs more generally during aggregate economic downturns, we first plot the stock prices of banks with high vs. low Liquidity Risk over the 2007 to 2009 period in Figure 5.

[Figure 5 about here]

We plot the difference in the stock price of banks with high vs. low Liquidity Risk indexed at January 1, 2007. The difference in the stock price performance between the two groups of banks is even more pronounced than during the COVID-19 crisis. Stock of banks with high Liquidity Risk fell by about $40 \%$ more than banks with low liquidity risk between Q2 2007 and Q3 2008. The stock price performance was then similar until the end of 2009.

We construct our variables at the end of Q4 2006 for our regressions in 2007 and at the end of Q4 2007 for the regressions in 2008 and 2009, and estimate equation (1) quarterly over the Q1 2007 to Q1 2009 period. The estimation results are reported in Table 6.

[Table 6 about here]

In Panel A of Table 6, we confirm that liquidity risk also episodically explained bank stock returns during the GFC, i.e., during the 2007 to 2009 period. Liquidity risk for banks rose in Q3 2007, i.e., in the first phase of the GFC, when the Asset Backed Commercial Paper (ABCP) market froze as documented in Acharya et al. (2013). Thereafter, liquidity risk remained priced in the cross-section of bank stock returns (and even increased in economic magnitude) until the end of Q2 2008. The Federal Reserve and U.S. government responded to the economic fallout of the Lehman Brothers default with a variety of measures to support the liquidity of the banking sector including large guarantee programs, following which we do not see any effect of liquidity risk on bank stock returns.

In Panel B of Table 6, we split Liquidity Risk into its components. While unused C\&I credit lines are clearly important, the results also show that wholesale funding exposure as well as having access to liquidity (i.e. cash) impacts bank stock returns, highlighting that a holistic 
measure of balance-sheet liquidity risk is useful. Otherwise we would force an average effect across banks for individual components.

Overall, episodes in which the balance-sheet liquidity risk of banks explains their stock returns seem to occur more broadly in aggregate economic downturns, when an aggregate liquidity demand for bank credit lines emerges.

\section{Understanding the mechanisms: Funding versus bank capital}

In this section, we investigate the mechanisms as to the effect of balance-sheet liquidity risk on bank stock returns during the COVID-19 pandemic. Does funding liquidity to source new loans become a binding constraint for banks when deposit funding dries up (the "funding channel")? Or, does the drawdown of credit lines lock up bank capital against term loans and impair bank loan origination, preventing banks from making possibly more profitable loans (the "capital channel")?

\subsection{Net versus gross credit-line drawdowns and bank stock returns}

To distinguish between the funding and capital channels, we construct two measures based on actual drawdowns experienced by our sample banks during the first quarter in 2020. Gross Drawdowns are defined as the percentage change of banks' off-balance-sheet unused C\&I loan commitments between Q4 2019 and Q1 2020 using call report data. Ivashina and Strahan (2012) and Li et al. (2020) show that lagged unused C\&I credit commitments are a good predictor for changes in banks' C\&I loans. We construct a second proxy, Net Drawdowns, which is defined as the absolute change in banks' unused C\&I commitments minus the change in deposits (all relative to total assets) over the same period. Holding gross drawdowns fixed, our measure of net drawdowns helps us understand the importance of changes in bank deposits on bank stock returns. In other words, Gross Drawdowns proxies for the importance of capital, while Net Drawdowns is a proxy for the importance of bank deposit funding; both measures help us identify the importance of the funding vs. capital channel. 
We plot the time-series of both measures since Q1 2010 in Figure 6. Panel A of Figure 6 shows the evolution of Gross Drawdowns. While Gross Drawdowns have been relatively stable since 2015 , we observe a sudden increase in credit-line drawdowns by about $13.5 \%$ from Q4 2019 to Q1 2020. As observed for banks' off-balance-sheet levels of unused C\&I loans, gross drawdowns had already reverted back to pre-COVID-19 levels by the end of Q2 2020 .

[Figure 6 about here]

Panel B of Figure 6 displays the development of Net Drawdowns since Q1 2010. Net Drawdowns have been relatively stable since 2015 and decreased by about 5\% in Q1 2020. In other words, the change in deposits during the first quarter 2020 has been larger than the change in unused C\&I commitments, suggesting that funding of new loans should not be a binding constraint for banks. Similar to gross drawdowns, net drawdowns also returned to pre-COVID19 levels over the next two quarters (i.e. in Q3 2020).

We investigate the effect of gross and net drawdowns on bank stock returns more formally using the model specification and control variables from column 5 of Panel A of Table 2. Instead of Liquidity Risk, we use our two new proxies to understand the importance of the funding vis-à-vis the capital channel. Table 7 reports the results.

[Table 7 about here]

We introduce both proxies sequentially in columns 1 and 2 and then together in column (3). The coefficient of Net Drawdowns is small and insignificant, while the coefficient of Gross Drawdowns is statistically significant and economically meaningful (column 2). A onestandard-deviation increase in Gross Drawdowns reduces bank stock returns by about 4.2\%, which is large. In magnitude it is similar to our Liquidity Risk proxy used in Table 2 earlier in this paper. We include both proxies in column 3 and find that, holding gross drawdowns fixed, net drawdowns have still no significant effect on bank stock returns. That is, as variation in net drawdowns is driven by changes in bank deposits (holding gross drawdowns fixed), funding of drawdowns through bank deposits does not appear to be a binding constraint for banks. 
In column 4, we observe the interaction between Gross Drawdowns and the Capital Buffer, which is the difference between a bank's equity-asset ratio and the cross-sectional average of the equity-asset-ratio of all sample banks in Q4 2019. A larger difference implies that a bank has a higher capital buffer. The coefficient of the interaction term is positive and significant emphasizing that the negative effect of drawdowns on stock returns is attenuated if banks fund their credit line exposure with more capital. Consistently, the coefficient of the interaction term of Capital Buffer and Net Drawdowns is not significant (column (5)). Using the change in bank deposits (Change Deposits) instead of net drawdowns provides qualitatively the same results (column (6)). Finally, adding SRISK/Assets as additional control (column 5) does not change the coefficient of Gross Drawdowns, suggesting that SRISK does not capture systemic implications associated with aggregate credit-line drawdowns.

\subsection{Implications for bank lending during the COVID-19 pandemic}

What does balance-sheet liquidity risk mean for bank lending during the COVID-19 pandemic? The increase in loan vis-à-vis bond spreads documented in Figure 2 in the introduction suggests that bank health was materially affected by the pandemic, and not just temporarily, impacting the access of firms to bank loans as well as the cost of bank credit. Loan-level data shows that bank issuance of new corporate loans has indeed substantially declined since the start of the COVID-19 pandemic. It is a testable hypothesis that banks with more balance-sheet liquidity risk reduced lending more relative to other banks. Moreover, if banks' capital constraints matter, we expect (term loan) lending to be particularly sensitive to gross (but not to net) drawdowns.

We use data from Dealscan to investigate these important issues. We use data on new loan originations in January 2019 to October 2020 and divide our sample into a pre and post period, where post is defined as the period starting April 1, 2020 (Q2 2020), i.e. during the COVID-19 pandemic. In unreported tests, we collapse our sample at the bank x month level and show that banks with higher Liquidity Risk and higher Gross Drawdowns decrease lending 
in the post relative to the pre-period and relative to banks with lower exposures using bank and month fixed effects. Net Drawdowns have no effect on lending. Banks reduce lending particularly to riskier borrowers consistent with higher capital requirements associated with these loans. However, while these tests are promising they do not allow us to control for loan demand. A plausible alternative explanation could be a reduction in loan demand due to lower investments from firms in a period characterized by high uncertainty. Another alternative explanation for a reduction in lending could be a loss of intermediation rents due to the lowinterest-rate environment.

Methodology. We use a Khwaja and Mian (2008) estimator to formally disentangle demand and supply in a regression framework, investigating the change in lending of banks to the same borrower before and after the outbreak of the COVID-19 pandemic. We construct a new variable, $\operatorname{Loan}_{i, b, m, t}$, which is the loan amount (or number of loans) issued to firm $i$ by bank $b$ as loan-type $m$ in month $t$. As our data contains syndicated loans, we use all banks and their lending to firm $i$ in a syndicate in the pre- and post-COVID-19 period. Absorbing loan demand shocks using borrower $\left(\eta_{i}\right)$, x bank $\left(\eta_{b}\right)$, x loan-type fixed effect $\left(\eta_{m}\right)$, we can isolate the effect of balance-sheet liquidity risk on bank loan supply:

$$
\operatorname{Loan}_{i, b, m}=\beta_{1} \times \text { Post }+\beta_{2} \times D D_{b} \times \text { Post }+\left(\eta_{i} \times \eta_{b} \times \eta_{m}\right)+\varepsilon_{i, b, m}
$$

Following Bertrand et al. (2004), we collapse our data on a firm x bankx loan-type level into a pre- and post-COVID-19 period to account for possible autocorrelation in the standard errors. $\operatorname{Loan}_{i, b, m}$ is the natural $\log$ of the loan amount (or natural log of 1 plus the number of loans) issued to firm $i$ by bank $b$ as loan-type $m$. A negative $\beta_{2}$ implies that a bank with more exposure to drawdown risk $\left(D D_{b}\right)$ - measured as either Gross or Net Drawdowns - decrease lending more than banks with less exposure during the COVID-19 pandemic after controlling for loan demand and other bank- and loan-specific effects via borrower $\mathrm{x}$ bank $\mathrm{x}$ tranche type 
fixed effects $\left(\eta_{i} \times \eta_{b} \times \eta_{m}\right)$. Gross and Net Drawdowns are measured over the Q1 2020 period and the post period starts, as explained above, in Q2 2020. We cluster standard errors on the borrower $\mathrm{x}$ bank $\mathrm{x}$ tranche level in all regressions.

Results. We provide results with the nat. $\log$ of loan amounts as dependent variable in Panel A of Table 8.

\section{[Table 8 about here]}

Banks that experienced larger gross drawdowns during Q1 2020 reduced lending more during the COVID-19 pandemic. The effect is highly statistically significant and economically large (column 1). A one-standard-deviation increase in Gross Drawdowns decreases loan amounts by $5 \%$. While the effect of Net Drawdowns is also significant (column 2), its economic meaning is smaller than Gross Drawdowns. When including both proxies in the regression, we find that the coefficient of Gross Drawdowns becomes smaller and statistically insignificant (column 3). $\beta_{1}$ is negative and significant suggesting that bank lending has, on average, decreased after the outbreak of COVID-19 across all banks. A possible explanation is the loss of intermediation rents for banks at large.

This regression, however, might mask the fact that both proxies are important but that capital or liquidity might play different roles depending on whether or not the loan needs to be fully funded at origination. We thus split the sample into term loans (column 4) and credit lines (column 5) and run the same regressions. As expected, banks with larger Gross Drawdowns reduce term lending more post-COVID-19 and banks with larger Net Drawdowns reduce credit commitments. That is, banks that experience net drawdowns appear to be reluctant to take on additional liquidity risk. Banks, however, can make term loans as long as they have capital to provide for them. Gross drawdowns reduce the available capital and thus term lending. The economic magnitudes of both proxies are similar to columns 1 and 2 . The statistical 
significance, however, is somewhat lower, as standard errors have increase, likely due to the smaller samples. ${ }^{21}$

We find very similar results when using the nat. $\log$ of 1 plus the number of loans as the dependent variable. The economic magnitude of Gross Drawdowns and thus the relative importance of the capital vis-à-vis the funding channel is even more pronounced.

\section{Contingent capital shortfall in a crisis}

Balance-sheet liquidity risk of banks - mainly driven by undrawn credit lines - has severe implications on their ability to extend new loans, because it requires capital once these credit lines are drawn. How can policy makers address aggregate drawdown risk in an ex-ante manner? One possible way is for regulators to add the effect of drawdowns to stress tests and require banks to fund these exposures with equity. In the last part of the paper, we quantify the capital shortfall that arises due to balance-sheet liquidity risk and show how balance sheet liquidity risk can be incorporated tractably into bank stress tests. Existing stress tests do not account for the impact of banks' contingent liabilities in times of stress. This is what we set out to do in this section.

\subsection{Methodology}

Capital shortfall in a systemic crisis (SRISK). SRISK is defined as the capital that a firm is expected to need if we have another financial crisis. Symbolically it can be defined as:

$$
\operatorname{SRISK}_{i, t}=E_{t}\left(\text { Capital Shortfall }{ }_{i} \mid \text { Crisis }\right)
$$

That is,

\footnotetext{
${ }^{21}$ Several papers provide evidence consistent with a reduction of banks' intermediation activity during COVID19. Chodorow-Reich et al. (2020) and Greenwald et al. (2020) show that banks cut credit lines and term lending to small firms because of credit line drawdowns of large firms, likely due to capital constraints. Moreover, we show in the Online Appendix that loan spreads of small firms in secondary loan markets have significantly increased vis-à-vis spreads of large firms since the beginning of the pandemic, consistent with a loss of intermediation activity for small firms dependent on bank financing.
} 


$$
\begin{aligned}
& S_{R I S K_{i, t}}=E[k(\text { Debt }+ \text { Equity })-E q u i t y \text { |Crisis }] \\
& =K \text { Debt }_{i, t}-(1-K)\left(1-\text { LRMES }_{i, t}\right) \text { Equity }_{i, t}
\end{aligned}
$$

where $D e b t_{i, t}$ is assumed to be constant between time $t$ and Crisis over $t$ to $t+h$. LRMES is the Long Run Marginal Expected Shortfall, approximated in Acharya et al. (2012) as $\left.1-e^{(-18 \times M E S}\right)$, where MES is the one-day loss expected in bank i's return if market returns are less than $-2 \%$ and Crisis is taken to be a scenario where the broad index falls by $40 \%$ over the next six months $(\mathrm{h}=6 \mathrm{~m}) . K$ is the regulatory capital ratio of $8 \%$.

As described above, such an impact can be broken down into two components. First, off-balance-sheet (i.e., contingent) liabilities enter banks' balance sheets as loans and need to be funded with capital. Second, we also have to account for the effects on stock returns as demonstrated in our calculations above.

"Contingent" capital shortfall in a systemic crisis (SRISK-C). We calculate the capital shortfall of banks in a systemic crisis with contingent liabilities as follows:

$$
S R I S K_{i, t}^{C}=\text { Incremental SRISK }_{i, t}^{C L}+\text { Incremental SRISK }_{i, t}^{L R M E S}{ }^{C}
$$

(i) Incremental SRISK $K_{i, t}^{C L}$ recognizes that drawdowns of credit lines in crisis states represent contingent liabilities of banks ( Debt $_{i, t+h} \mid$ Crisis $\neq$ Debt $\left._{i, t}\right)$ :

$$
\begin{aligned}
& \text { Incremental SRISK }_{i, t}^{C L}=K\left[E\left[\text { Debt }_{i, t+h} \mid \text { Crisis }\right]-\text { Debt }_{i, t}\right] \\
& =K \times E[\text { Drawdown rate } \mid \text { Crisis }] \times \text { Unused Commitments }_{i, t}
\end{aligned}
$$

$E[$ Drawdown rate $\mid$ Crisis $]$ is estimated using past drawdown rates extrapolated for a market index fall of $40 \%$. 
(ii) Incremental SRISK $K_{i, t}^{\text {LRMES }}{ }^{C}$ recognizes that LRMES estimated using "small" (or local) $2 \%$ market corrections in normal times does not account for the episodic effect of balance-sheet liquidity risk on bank stock returns:

$$
\text { Incremental SRISK }_{i, t}^{L_{\text {RMES }}{ }^{C}}=(1-K) \times \Delta L R M E S_{i, t}^{C} \times \text { Equity }_{i, t},
$$

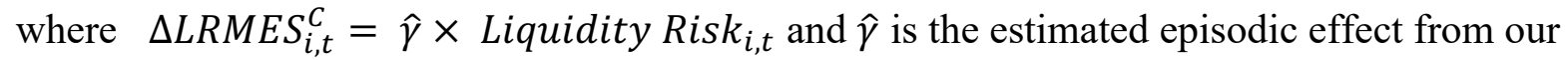
tests on balance-sheet liquidity risk.

\subsection{Estimating the drawdown function}

To calculate the expected percentage drawdown in a crisis, we use drawdown data during the COVID-19 pandemic as well as the GFC crisis and estimate the expected drawdown in a stress scenario with a $40 \%$ market correction for both stressed periods. We show plots of this exercise in Figure 7.

\section{[Figure 7]}

In Panel A of Figure 7, we plot the cumulative quarterly drawdown rates during the COVID-19 pandemic (i.e. Q4 2019 and Q1 2020) and the GFC (i.e. the Q1 2007 to Q4 2009 period) on the respective quarterly S\&P 500 returns. We also show the linear regressions for both periods. In Panel B of Figure 7, we use the lowest cumulative daily S\&P 500 return within each quarter (instead of the quarterly return). This presentation has two advantages. First, it shows that for quarters with relatively low negative S\&P 500 returns (i.e. "normal times"), drawdowns are somewhat clustered. ${ }^{22}$ Second, drawdown decisions are arguably based on how bad a quarter has actually been rather than on the situation at the end of each quarter. We therefore calculate drawdown rates based on Panel B of Figure 7.

We find that the sensitivity of credit-line drawdowns to changes in market returns was higher during the COVID-19 pandemic (the slope coefficient, the $\beta$, is -0.57) compared with

\footnotetext{
${ }^{22}$ The intercept in the COVID-19 pandemic and the GFC are $17 \%$ and $15 \%$, respectively.
} 
the GFC (the slope coefficient is -0.27). The projected drawdown rate in a market downturn of $40 \%(-40 \% \times \beta)$ is thus also substantially higher in the COVID-19 pandemic $(22.91 \%$ vs. $10.82 \%$ ). A possible explanation of the differential impact on absolute drawdowns could be that corporate balance sheets were less impacted during the GFC, which originated in the banking and household sector. The COVID-19 pandemic, however, had an immediate effect on firms' balance sheets, resulting in elevated demand for liquidity from pre-arranged credit lines compared with the GFC.

The quarterly drawdown rates in both stress scenarios or crises are summarized together with the sensitivities of the drawdown rates in a market correction in Panel A of Table 9.

\section{[Table 9 about here]}

\subsection{Incremental SRISK due to credit line drawdowns}

Using these expected drawdown rates, we calculate the equity capital that would be required to fund these new loans based on banks' unused commitments at the end of Q4 2019 (Incremental SRISK $K_{i}^{C L}$ ). We use the Q4 2019 unused credit line commitments of banks and apply the drawdown rates calculated in the three different stress scenarios assuming a prudential capital ratio of $8 \%$ :

Incremental SRISK $K_{i}^{C L}=$ Drawdown rate $\times 8 \% \times$ Unused Commitments

In Panel B of Table 9, we show the top 10 banks with the largest undrawn commitments as of Q4 2019 and report Incremental SRISK $K_{i}^{C L}$ individually for each of these banks. We also report the total Incremental SRISK ${ }^{C L}$ for the top 10 and for all banks in our sample. Overall, we find that Incremental SRISK ${ }^{C L}$, i.e, the additional capital, amounts to about USD 36bn to USD $65 \mathrm{bn}$ depending on the estimates of the drawdown rate.

\subsection{Incremental SRISK due to MES $^{\mathrm{C}}$ and contingent SRISK $\left(\right.$ SRISK $^{\mathrm{C}}$ )}


We also accounte for the effect of liquidity risk on bank stock returns as demonstrated in our calculations above. Using the loadings from our regressions of bank stock returns on balancesheet liquidity risk during the COVID-19 crisis (i.e, the $\gamma$ in equation (2)), we estimate the additional (marginal) equity shortfall of banks based on their end of Q4 2019 market values of equity $(M V)$, called the Incremental SRISK ${ }_{i}^{L^{2 M E S}{ }^{C}}$ :

$$
\begin{gathered}
\text { Incremental SRISK }_{i}^{\text {LRMES }^{C}}=(1-k) \times M V_{i} \times \operatorname{LRMES}_{i}^{C} \\
=(1-k) \times M V_{i} \times \hat{\gamma} \times \text { Liquidity Risk }_{i}
\end{gathered}
$$

$L R M E S_{i}^{C}$ is contingent marginal expected shortfall due to the impact of liquidity risk on bank stock returns. We report the Incremental SRISK $K_{i}^{L R M E S^{C}}$ in Panel C of Table 9.

We use a minimum and maximum loading $(\gamma)$ estimated from different regressions based on equation (1) and calculate a range of $L R M E S_{\min }^{C}$ and $L R M E S_{\max }^{C}$, which is between $6.9 \%$ and $24.9 \%$. The corresponding Incremental SRISK ${ }_{i}^{L R M E S^{C}}$ amounts to USD $158 \mathrm{bn}$ to USD $250 \mathrm{bn}$.

In a final step, we calculate the conditional SRISK $\left(S R I S K^{C}\right)$ adding the two incremental SRISK components. Adding both components we show that the additional capital shortfall for the U.S. banking sector due to balance-sheet liquidity risk amounts to more than $\$ 300$ billion as of 31 December 2019 in a stress scenario of a $40 \%$ correction to the global stock market, with the top 10 banks contributing USD $265 \mathrm{bn}$. The incremental capital shortfall of the top 10 banks is about 1.6 times the SRISK estimate without accounting for contingent liabilities and the effect of liquidity risk.

Overall, our estimates show that the incremental capital shortfall in an aggregate economic downturn due to banks' contingent liabilities is sizeable, because it requires an additional amount of capital to fund the new loans on their balance sheets, and, importantly, 
because of an (even larger) incremental capital requirement due to an episodic impact of bank balance-sheet liquidity risk on bank stock returns.

\section{Discussion}

Finally, we discuss the robustness of our results and their extensions along three dimensions: (1) alternative liquidity proxies used in the literature; (2) pricing of contingent drawdown options through credit-line fees; and (3) the role of covenants during the pandemic.

\subsection{Liquidity proxies}

We propose and developed a new measure of balance-sheet liquidity risk as there is no consensus in the literature on how to measure liquidity risk. In this section, we compare our measure with two frequently used measures in the literature, the Berger and Bouwman (2009) liquidity creation measure $(B B)$ and the Bai et al. (2018) liquidity risk measure $(L M I) . B B$ is a stock measure including banks' on and off-balance-sheet positions. In contrast, the $L M I$ is a contemporaneous measure as it incorporates current market liquidity conditions (using the OIS - 3m Treasury Bill spread as a liability weight). We create two LMIs, one using liquidity conditions as of Q4 2019 (LMI - 2019) and one using the worst liquidity condition in March 2020 (LMI - 2020). We provide a more detailed discussion of the creation of the liquidity measures and the results in Online Appendix D. Below is a brief summary.

We estimate regression (1) using the alternative liquidity proxies. We find that the BB measure is negatively and significantly related to stock returns during the $3 / 1 / 2020$ to3/23/2020 period; however, the effect is somewhat moderate compared with both Liquidity Risk and Unused C\&I / Assets. In unreported tests, we run a horse race of Liquidity Risk and both alternative liquidity measures in separate regressions. Both $L M I$ and $B B$ become small and insignificant, while Liquidity Risk remains negative and significant, suggesting that Liquidity Risk contains information not captured in these alternative liquidity proxies. $L M I-2019$ has only a small and statistically insignificant effect due to benign liquidity conditions in financial 
markets at the end of 2019. LMI - 2020, however, has a large, significant impact on stock returns and is also highly correlated with Liquidity Risk. This is consistent with the interpretation that a worsening of liquidity conditions in financial markets increases aggregate drawdown risk for banks, thereby increasing the value of the put option, which negatively impacts bank stock returns.

\subsection{Credit line fees}

Do banks price aggregate drawdown risk through fees and/or credit spreads when issuing new credit lines? In Online Appendix E, we investigate this question using all credit lines issued to U.S. non-financial firms over the 2010 to 2019 period, sourced from Refinitiv Dealscan. We first show that idiosyncratic drawdown risk (measured using a firm's realized equity volatility over the past 12 months) and systematic drawdown risk (measured using a firm's stock beta) are priced in both commitment fee (AISU) and spread (AISD). This is consistent with, for example, Acharya et al. (2013) and Berg et al. (2015).

However, while a higher Bank Beta and LRMES both somewhat increase the price of credit lines, Liquidity Risk or Unused C\&I / Assets, on average, do not. Also, SRISK / Assets, which measures bank capital shortfall in times of aggregate market downturn, does not appear to be priced either. In other words, banks do not appear to be considering the deep out-of-themoney put option associated with aggregate drawdown risk when setting ex-ante price terms of credit lines. This may partly explain their need to fund aggregate drawdown risk with equity capital, as witnessed during the pandemic.

\subsection{Covenants}

Did covenants constrain drawdowns of credit lines at the beginning of the pandemic in March 2020, or later during the year when firms' financial situation had deteriorated? We follow the extant literature (e.g., Roberts and Sufi, 2008) and use textual analysis to identify all loan amendments of publicly listed U.S. non-financial firms in SEC filings sourced from EDGAR from March to Q3 2020. We found that not a single loan amendment was initiated through a 
covenant violation. On the contrary, banks and firms regularly negotiated a covenant relief period (usually up to Q1 2021 or later) early in the pandemic to account for its fallout. In summary, credit line drawdowns (also by firms in the hardest-hit industries) did not appear to be constrained by possible covenant violations during the pandemic.

\section{Conclusion}

We document that the balance-sheet liquidity risk of banks is an explanation for the significant and persistent underperformance of bank stocks relative to other financial and non-financial firms during the COVID-19 pandemic. It explains both the cross-section and the time-series of bank returns during the pandemic but not before. This episodic impact of balance-sheet liquidity risk on bank stock returns is not unique to the COVID-19 crisis, and was also seen during the global financial crisis, i.e., during the 2007 to 2009 crisis. That is, balance-sheet liquidity risk of banks affects bank stock prices during an aggregate economic downturn when firms' liquidity demand through credit-line drawdowns becomes highly correlated, but not before.

Importantly, bank stock returns react adversely to gross drawdowns rather than net drawdowns (which account for inflows in bank deposits), suggesting that bank capital is a binding constraint to intermediation activity by banks as perceived by markets. Consistently, we show that banks with large gross drawdowns reduce their immediate supply of term loans (not credit lines); banks with less deposit inflows, however, reduce credit line originations. We demonstrate how the episodic nature of credit-line drawdowns and balance-sheet liquidity risk can be incorporated tractably into bank stress tests.

Darmouni and Siani (2020) show that U.S. non-financial firms issued bonds following the monetary policy and fiscal interventions in March 2020 and used the proceeds to repay credit lines. While a large proportion of credit lines has been repaid in Q2 and Q3 2020, corporate preference for cash of firms has remained high (Online Appendix B) and total debt on firms' balance sheet has substantially increased. The non-financial-sector leverage and 
exposure to capital markets has thus increased further during the COVID-19 pandemic. In other words, ex-ante aggregate drawdown risk of banks is again high (e.g., in case of another wave of the pandemic or due to another aggregate shock). In turn, the value of the put option in the form of bank credit lines for corporates and capital markets would be even more pronounced if liquidity conditions were to severely deteriorate. In summary, additional corporate leverage accumulated during the initial phase of the pandemic has increased the likelihood of future impact on bank stock returns via the credit-line drawdown channel. 


\section{References}

Acharya, V., R. Engle, and M. Richardson, 2012, Capital shortfall: a new approach to ranking and regulating systemic risks. American Economic Review 102, 59-64.

Acharya, V. and N. Mora, 2015, A Crisis of Banks as Liquidity Providers, Journal of Finance, $2015,70(1), 1-44$.

Acharya, V., L. Pedersen, T. Philippon, and M. Richardson, 2016, Measuring systemic risk, Review of Financial Studies, 30, 2-47.

Acharya, V., P. Schnabl, G. Suarez, 2013, Securitization Without Risk Transfer, Journal of Financial Economics, 107, 515-536

Acharya, V., and S. Steffen, 2020a, 'Stress tests' for banks as liquidity insurers in a time of COVID. CEPR VoxEU.org.

Acharya, V., and S. Steffen, 2020b, The risk of being a fallen angel and the corporate dash for cash in the midst of COVID. Review of Corporate Finance Studies 9 (3), 430-471.

Adrian, T. and M. Brunnermeier, 2016, American Economic Review 106 (7), 1705-1741.

Allen, F., and D. Gale. 2004. Financial Intermediaries and Markets. Econometrica 72:1023-61.

Allen, F., and A. M. Santomero. 1998. The Theory of Financial Intermediation. Journal of Banking and Finance 21:1461-85.

Bai, J., A. Krishnamurthy, C.-H. Weymuller, 2018, Measuring liquidity mismatch in the banking sector. Journal of Finance 73, 51-93.

Behn, M., R. Haselmann, and V. Vig, 2016, The limits of model-based regulation, Working Paper.

Berg, T., A. Saunders and S. Steffen, 2016, The Total Cost of Borrowing in the Loan Market Don't Ignore the Fees, Journal of Finance, 71(3), 1357-1392.

Berg, T., A. Saunders, S. Steffen and D. Streitz, 2017, Mind the Gap: The Difference between U.S. and European Loan Rates, Review of Financial Studies, 30(3), 948-987. 
Berger, A., and C. Bouwman, 2009, Bank liquidity creation, Review of Financial Studies, 22(9), $3779-3837$.

Bhattacharya, S., and A. V. Thakor. 1993. Contemporary Banking Theory. Journal of Financial Intermediation 3:2-50

Brownlees, C., and R. Engle, 2017, SRISK: A Conditional Capital Shortfall Measure of Systemic Risk, Review of Financial Studies, 30 (1), 48-79.

Chodorow-Reich, G., O. Darmouni, S. Luck, and M. Plosser, 2020, Bank liquidity provision across the firm size distribution, Working Paper.

Cornett, M., J. McNutt, P. Strahan, and H. Tehranian, 2011, Liquidity risk management and credit supply in the financial crisis. Journal of Financial Economics, 101(2), pp.297312.

Coval, J. D., and A. V. Thakor. 2005. Financial Intermediation as a Beliefs-Bridge between Optimists and Pessimists. Journal of Financial Economics 75:535-69.

Darmouni, O., and K. Y. Siani, 2020. Crowding Out Bank Loans: Liquidity-Driven Bond Issuance. Working Paper, Columbia University.

Deep, A., and G. Schaefer. 2004. Are Banks Liquidity Transformers? Working Paper, Harvard University.

Demsetz, R., and P. Strahan, 1997, Diversification, size, and risk at bank holding companies, Journal of Money, Credit and Banking 29(3), 300-313.

Gatev, E., and P. Strahan, 2006, Banks' Advantage in Hedging Liquidity Risk: Theory and Evidence from the Commercial Paper Market. Journal of Finance 61(2), 867-892.

Demirguc-Kunt, A., A. Pedraza, and C. Ruiz-Ortega, 2020, Banking sector performance during the COVID-19 crisis, Working Paper, World Bank.

Egan, M., S. Lewellen, A. Sunderam, 2020, The cross section of bank value. Working Paper. 
Fahlenbrach, R., R. Prilmeier, and R.s M. Stulz, 2012, This Time is the Same: Using Bank Performance in 1998 to Explain Bank Performance During the Recent Financial Crisis, Journal of Finance 67, 2139-2185.

Fahlenbrach, R., K. Rageth, and R. M. Stulz, 2020, How valuable is financial flexibility when revenue stops? Evidence from the Covid-19 crisis. Review of Financial Studies, forthcoming.

Gilchrist, S., and E. Zakrajšek. 2012. "Credit Spreads and Business Cycle Fluctuations." American Economic Review 102 (4): 1692-1720.

Gormsen, N. J., and R. S. J. Koijen. 2020. Coronavirus: Impact on stock prices and growth expectations. Review of Asset Pricing Studies 10 (4), 574-597.

Greenwald, D. L., J. Krainer, and P. Paul, 2020, The credit line channel, Working Paper.

Holmstrom, B., and J. Tirole. 1998. Public and Private Supply of Liquidity. Journal of Political Economy 106:1-40.

Ivashina, V., and D. Scharfstein, 2010, Bank Lending During the Financial Crisis of 2008, Journal of Financial Economics, 97(3), 319-338.

Kapan, T., and C. Minoiu, 2020, Liquidity Insurance vs. Credit Provision: Evidence from the COVID-19 Crisis, Working Paper.

Kashyap, A., R. Rajan and J. Stein, 2002, Banks as Liquidity Providers: An Explanation for the Coexistence of Lending and Deposit-taking, Journal of Finance 57(1) 33.73.

Landier, A., and D. Thesmar, 2020, Earnings Expectations in the COVID Crisis, MIT Working Paper.

Li, L., and P. Strahan, 2020, Who Supplies PPP Loans (And Does it Matter)? Banks, Relationships and the COVID Crisis, NBER Working Paper.

Li, L., P. Strahan, and S. Zhang, 2020, Banks as Lenders of First Resort: Evidence from the COVID-19 Crisis, Review of Corporate Finance Studies 9(3), 472-500. 
Pagano, M., C. Wagner, and J. Zechner, 2020, Disaster resilience and asset prices. Working Paper, University of Naples.

Ramelli, S., and A. F. Wagner, 2020, Feverish stock price reactions to COVID-19. Review of Corporate Finance Studies 9 (3), 622-655.

Repullo, R. 2004. Capital Requirements, Market Power, and Risk-Taking in Banking. Journal of Financial Intermediation 13:156-82.

Saunders, A., A. Spina, S. Steffen, and D. Streitz, 2021, Corporate loan spreads and economic activity, Working Paper.

Von Thadden, E.-L. 2004. Bank Capital Adequacy Regulation under the New Basel Accord. Journal of Financial Intermediation 13:90-95. 
Figure 1. Cumulative drawdowns and bank stock prices

Panel A shows the cumulative credit line drawdowns of U.S. firms over the March 1, 2020 to July 1, 2020 period in billion USD. Panel B shows the stock prices of U.S. firms by sector, specifically firms from the energy, banking and other sectors, since Jan $1^{\text {st }}$, 2020. All variables are defined in Appendix II.

Panel A. Cumulative drawdowns (in USD bn)

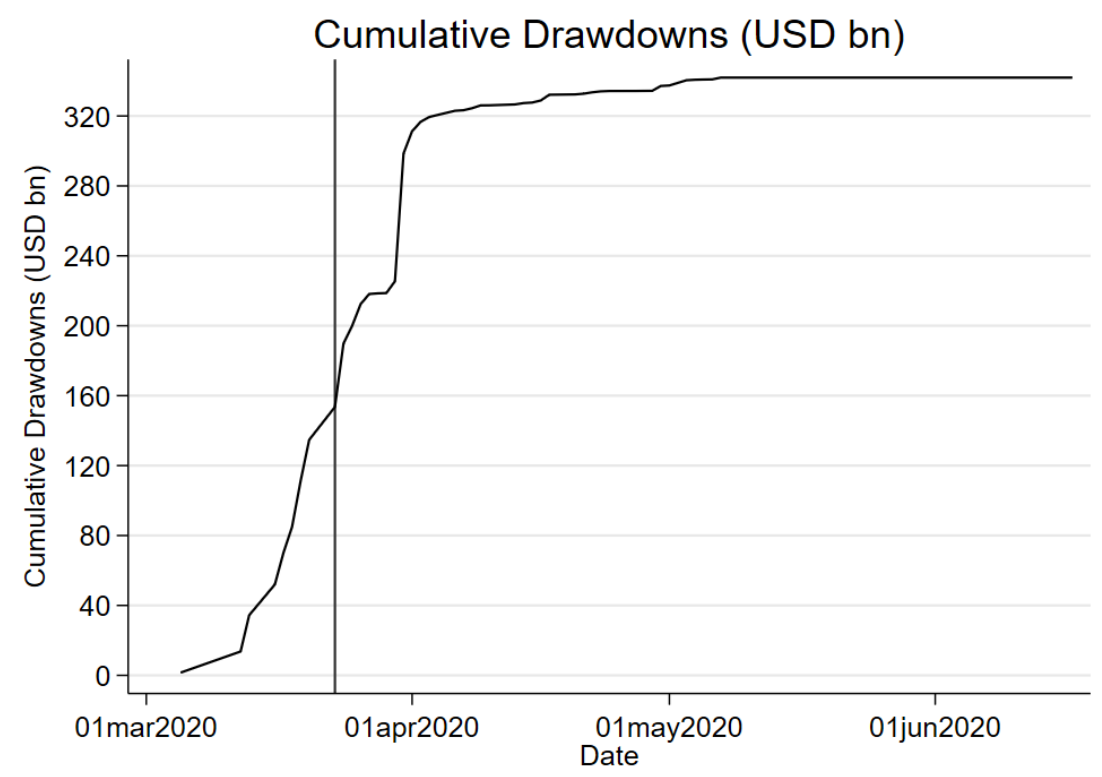

Panel B. Stock prices of banks vs. non-financial firms

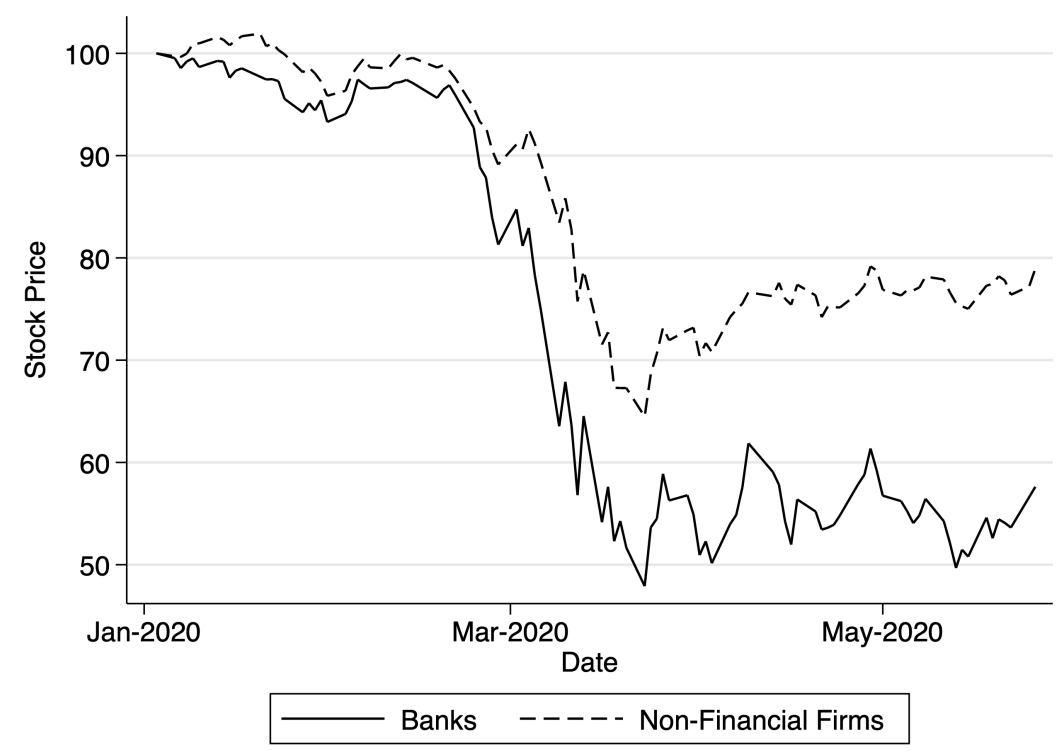




\section{Figure 2. Loan vs. bond spreads}

This figure shows the time-series difference of loan and bond spreads (Panel A) and splitting loans by rating classes (Panel B). The loan spread is calculated based on Saunders et al. (2021). The sample is based on all loans traded in 2020 that were traded in the U.S. Leveraged Loan Index (LLI) obtained from Leveraged Commentary and Data (LCD) and matched to secondary loan market trading data from Refinitiv. The sample thus comprises about 1,000 U.S. non-financial firms. $3 \%$ of the observations are unrated (based on S\&P ratings), $25 \%$ are CCC-C rated, $54 \%$ are $\mathrm{B}$ rated, $15 \% \mathrm{BB}$ rated and 3\% BBB rated. Loans with a "D" rating are dropped from the sample (35 firms). Loan spreads are constructed using a weighted average (with facility amounts as weights). Bond spreads are constructed based on Gilchrist and Zakrajšek (2012) and obtained from the Federal Reserve website.

\section{Panel A. Loan-bond-spread difference}

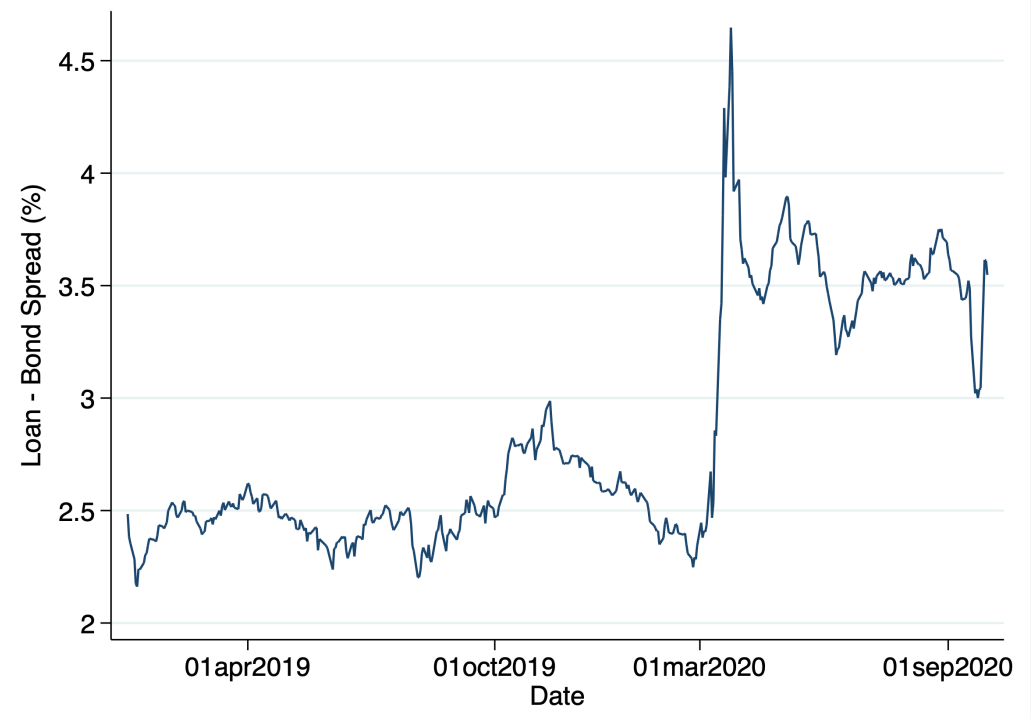

Panel B. Loan-bond-spread difference (by rating)

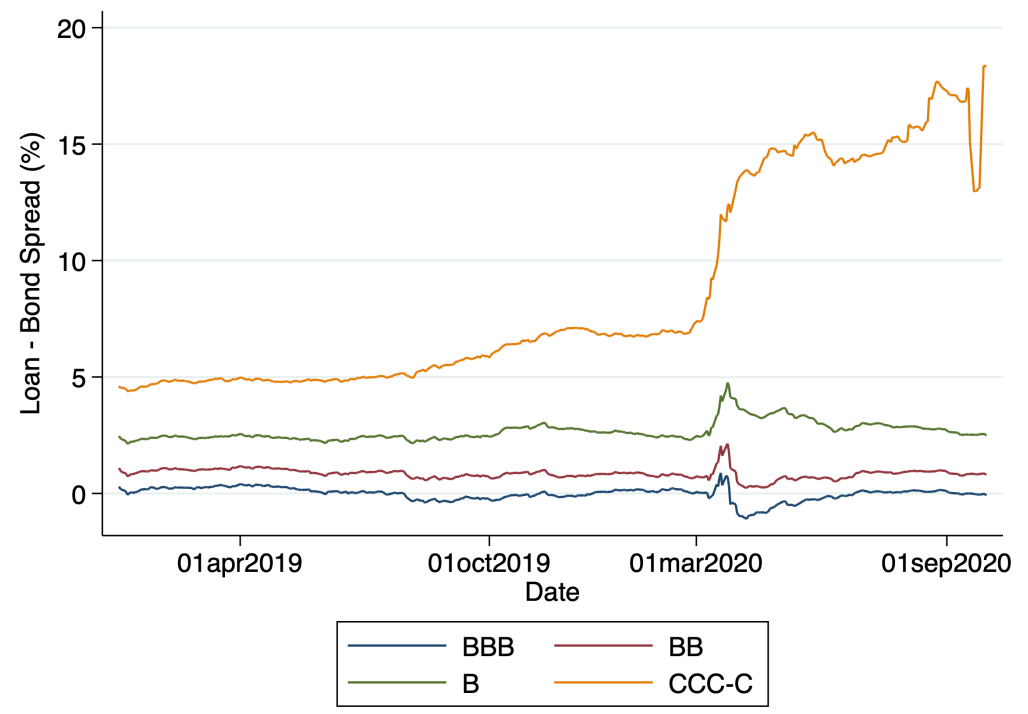




\section{Figure 3. Bank balance-sheet liquidity risk}

This figure shows the time-series of balance-sheet Liquidity Risk over the Q1 2010 to Q3 2020 period. We measure Liquidity Risk as undrawn commitments plus wholesale finance minus cash or cash equivalents (all relative to assets). All variables are defined in Appendix II.

\section{Panel A. Liquidity risk}

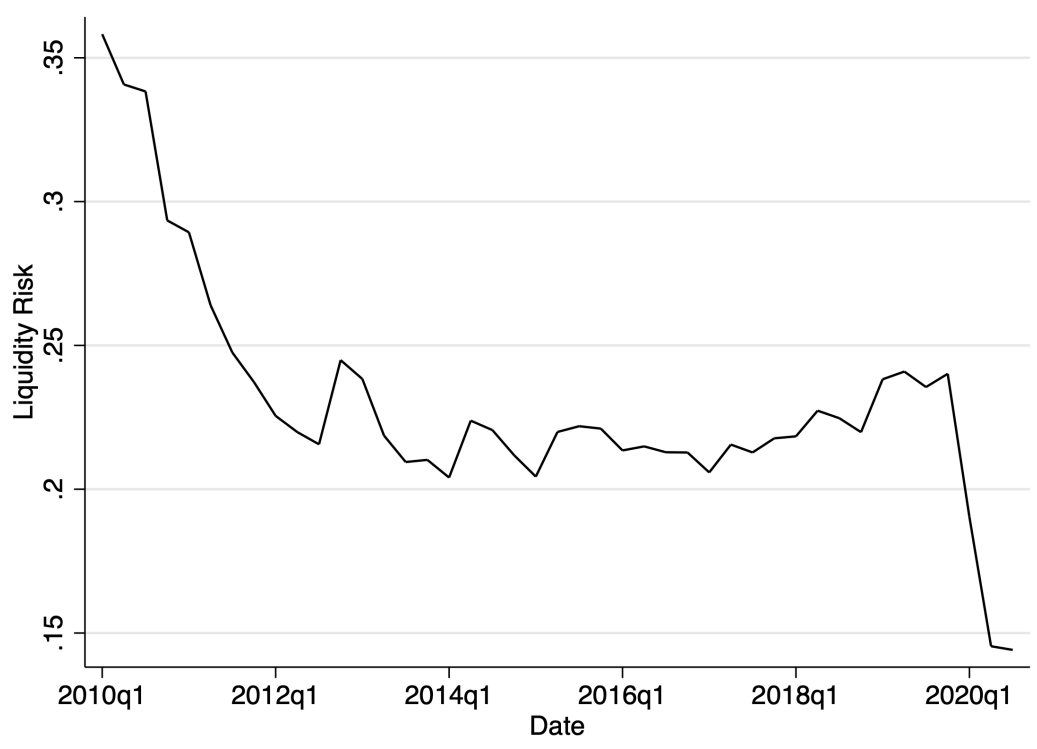

\section{Panel B. Components of liquidity risk}

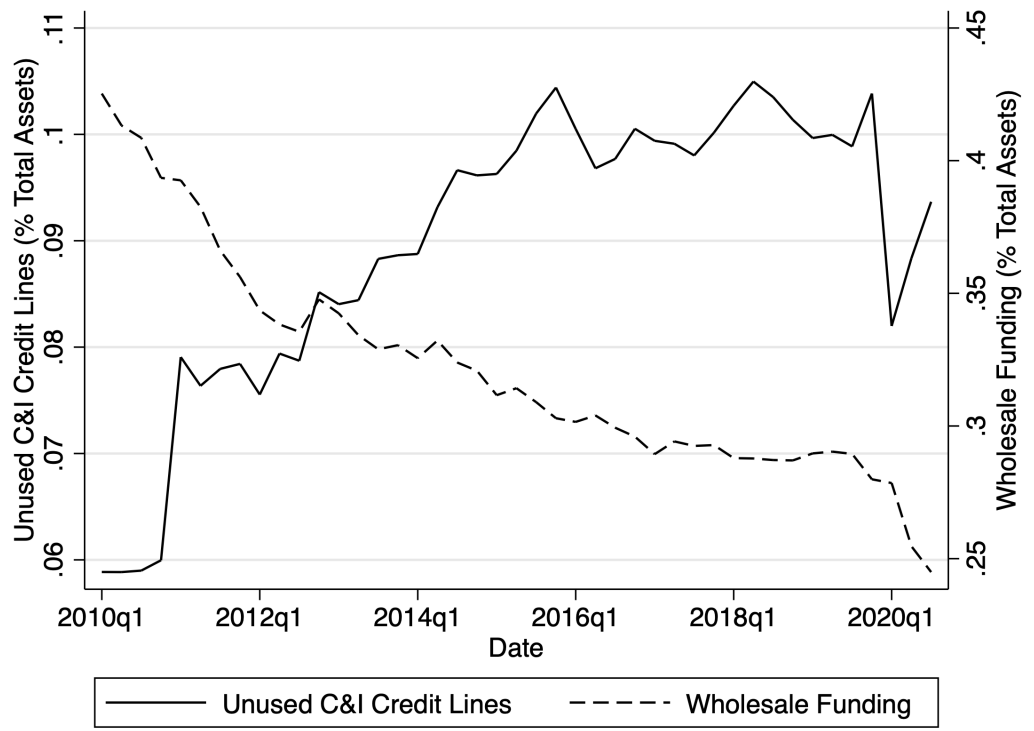




\section{Figure 4. Stock prices and liquidity risk of U.S. banks}

This figure shows stock prices of U.S. banks with Low or High Liquidity Risk. We measure Liquidity Risk as undrawn commitments plus wholesale finance minus cash or cash equivalents (all relative to assets) and use a median split to distinguish between banks with Low vs. High Liquidity Risk. Panel A shows the stock prices of both group of banks indexed at Jan 1, 2020, Panel B shows the difference between the stock prices (in percentage point). Panel B plots bank stock returns during the March 1 - March 23, 2020 period on Liquidity Risk. All variables are defined in Appendix II.

Panel A. Bank stock returns

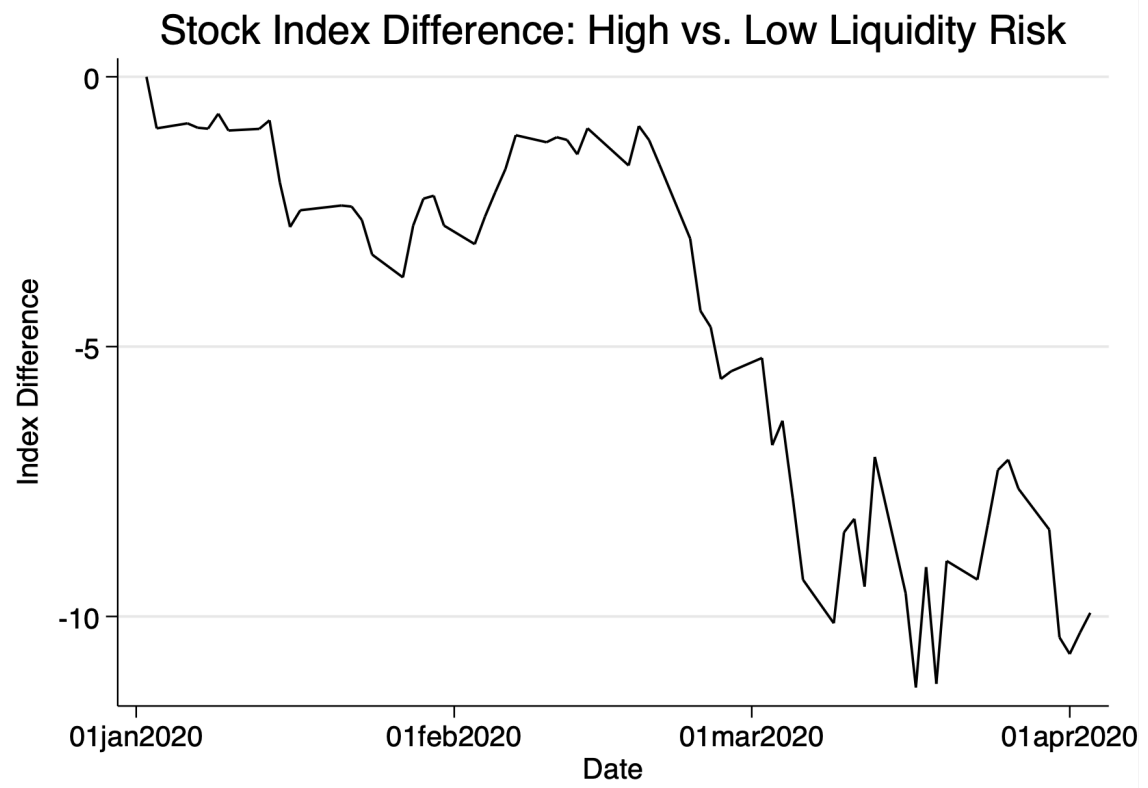

Panel B. Bank stock return and liquidity risk

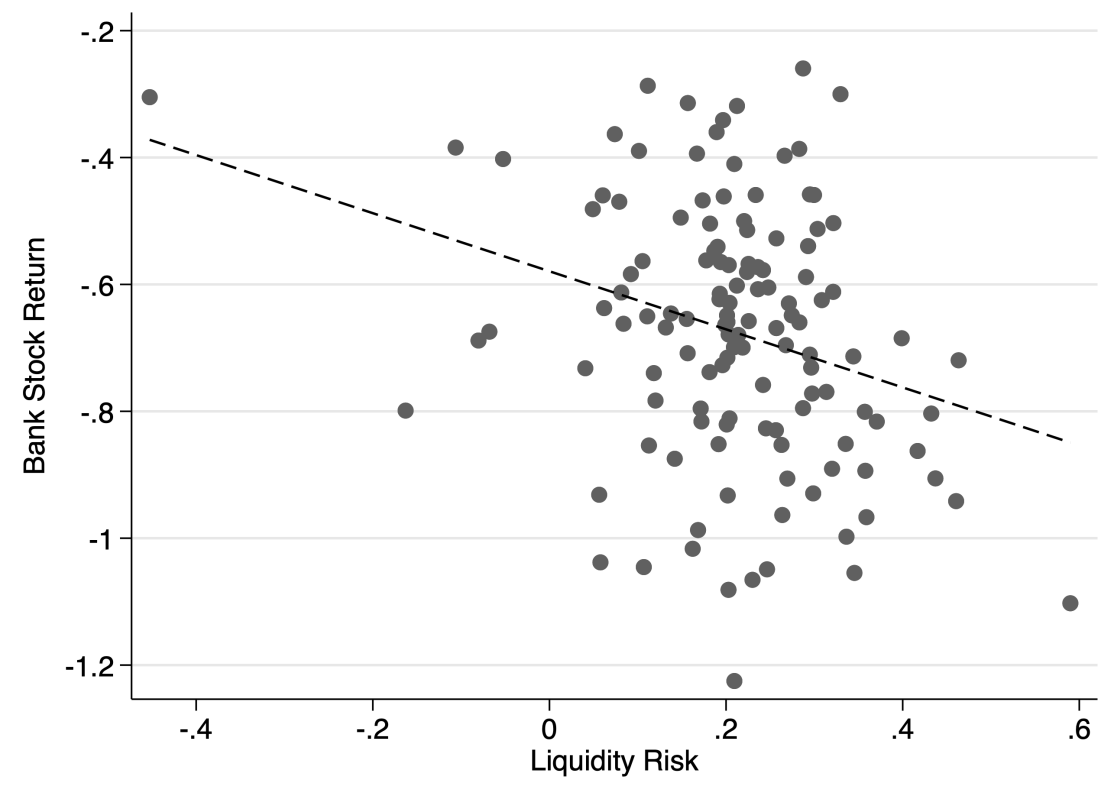


Figure 5. Stock prices and liquidity risk of U.S. banks (2007-2009)

This figure shows stock prices of U.S. banks with Low or High Liquidity Risk for the Jan 2007 to Jan 2010 period. We measure Liquidity Risk.as undrawn commitments plus wholesale finance minus cash or cash equivalents (all relative to assets) and use a median split to distinguish between banks with Low vs. High Liquidity Risk. Panel A shows the stock prices of both group of banks indexed at Jan 1, 2007, Panel B shows the difference between the stock prices (in percentage point). All variables are defined in Appendix II.

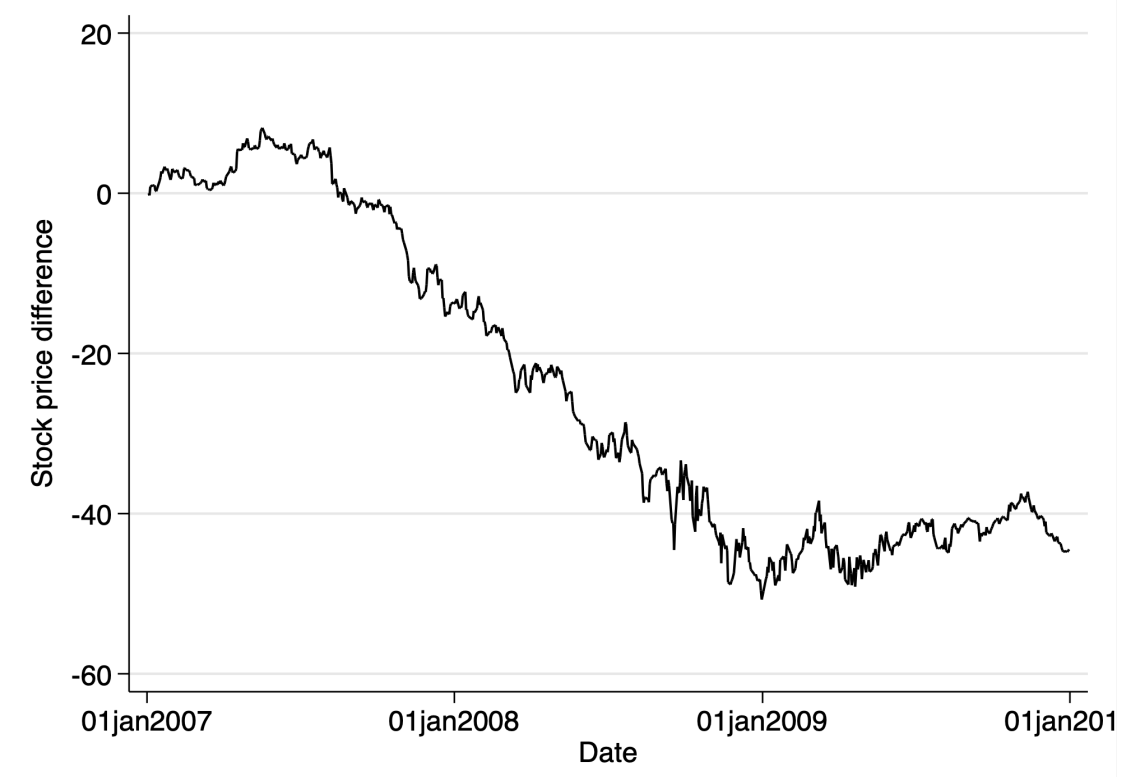


Figure 6. Net vs. gross drawdowns

This figure shows the time-series of Gross Drawdowns (Panel A) and Net Drawdowns (Panel B) over the Q1 2010 to Q3 2020 period. Gross Drawdowns is the percentage change in a bank's off balance sheet unused C\&I loan commitments (measured during Q1 2020). Net Drawdowns are defined as the change in a bank's off balance sheet unused C\&I loan commitments minus the change in deposits (all measured during Q1 2020) relative to total assets. All variables are defined in Appendix II.

\section{Panel A. Gross Drawdowns}

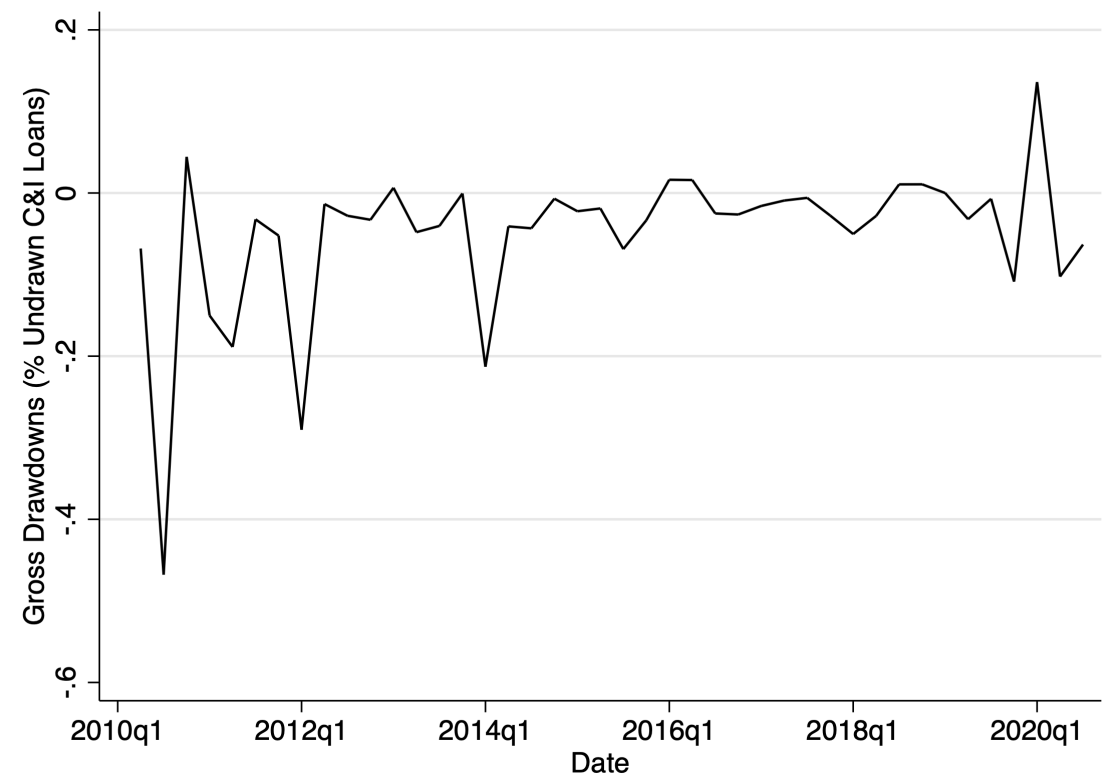

\section{Panel B. Net Drawdowns}

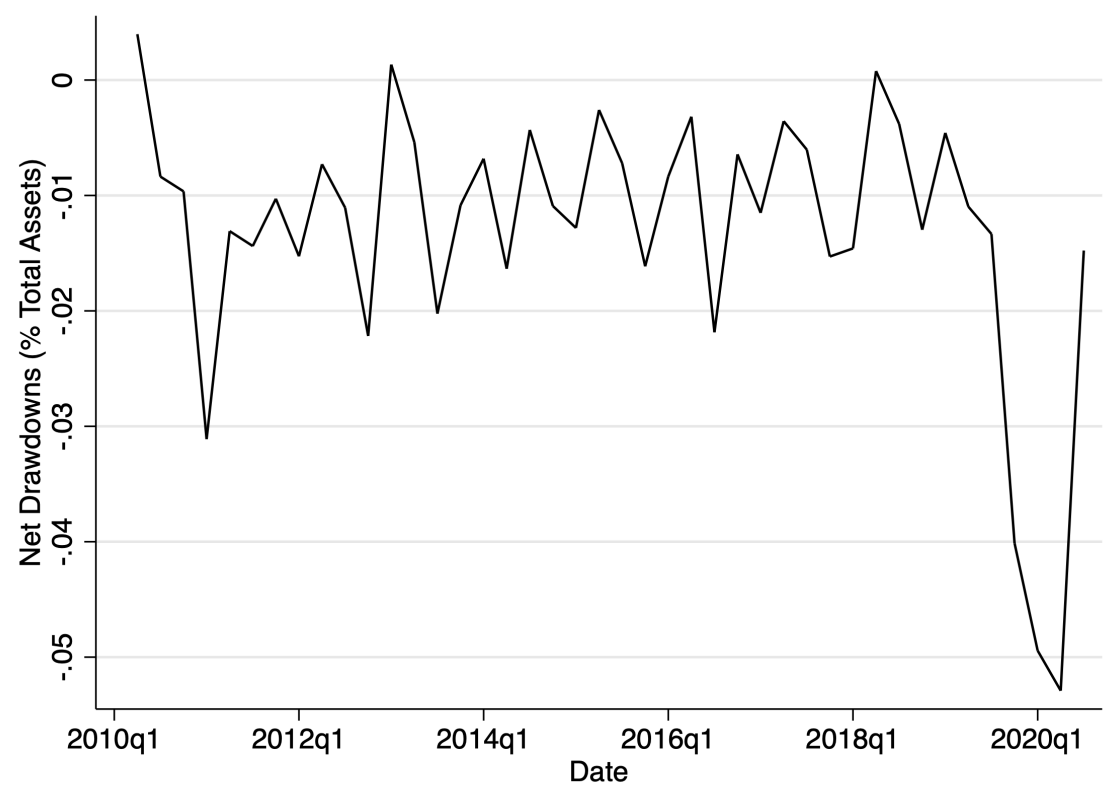




\section{Figure 7. Credit line drawdowns and market returns}

This figure plots the cumulative drawdown of credit lines of non-financial firms on the cumulative market return (using the S\&P 500 as the market). In Panel A, we plot the cumulative quarterly drawdown rates during the COVID-19 pandemic (i.e. Q4 2019 and Q1 2020) and the GFC (i.e. the Q1 2007 to Q4 2009 period) on the respective quarterly S\&P 500 returns. We also show the linear regressions for both periods. In Panel B of Figure 6 , we use the lowest cumulative daily S\&P 500 return within each quarter (instead of the quarterly return). All variables are defined in Appendix II.

Panel A. Quarterly drawdowns vs quarterly S\&P 500 returns

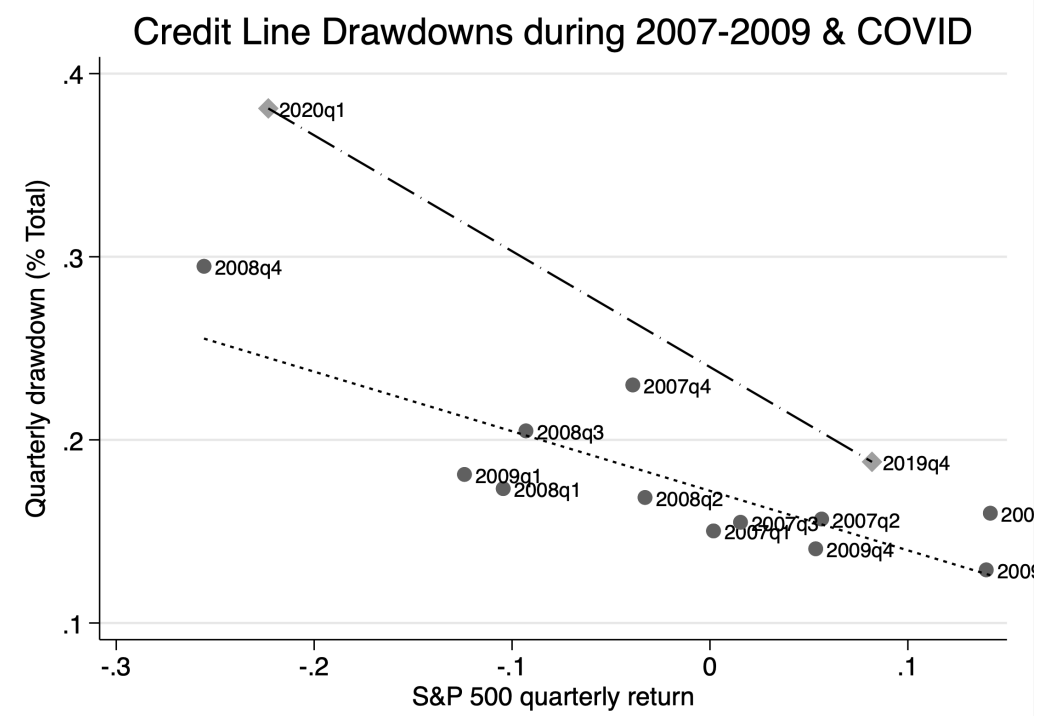

Panel B. Quarterly drawdowns vs lowest cumulative S\&P 500 return in each quarter

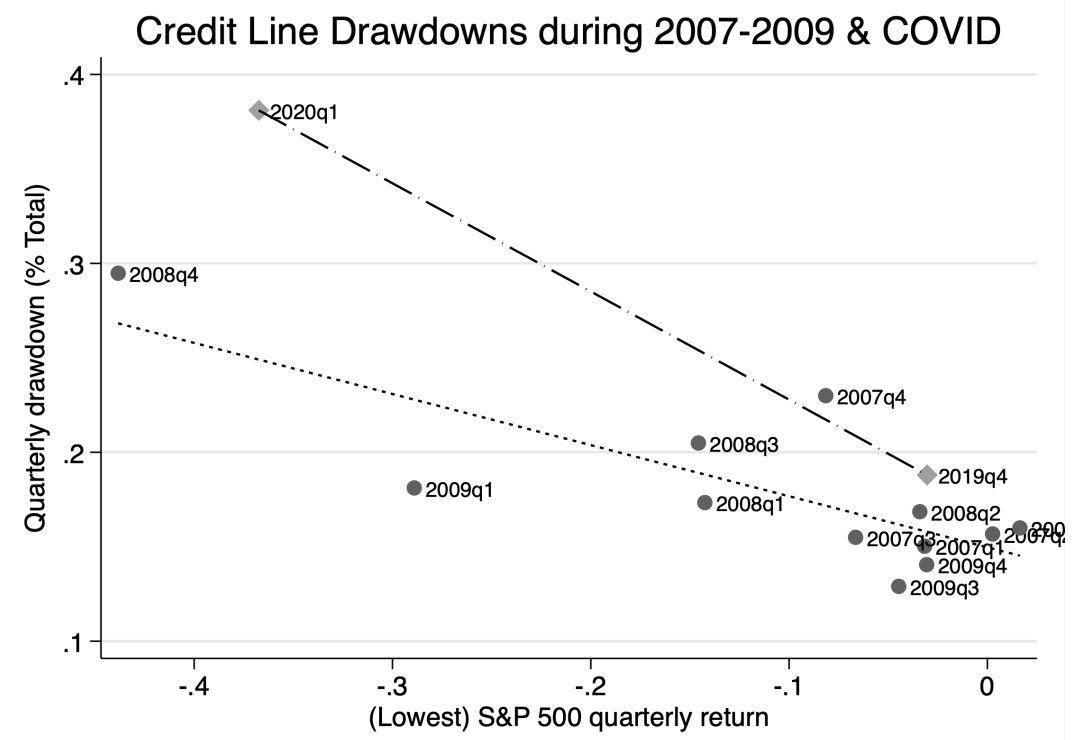


Table 1. Descriptive statistics

Table 1 shows descriptive statistics of the variables included in the cross-sectional regressions. All variables are defined in Appendix II.

Panel A. Bank stock returns

\begin{tabular}{lccccc}
\hline Variable & Obs. & Mean & Std. dev. & Min & Max \\
\hline Return January 2020 & 127 & -0.079 & 0.039 & -0.181 & 0.024 \\
Return February 2020 & 127 & -0.125 & 0.037 & -0.194 & 0.011 \\
Return 3/1-3/23 2020 & 127 & -0.471 & 0.184 & -1.084 & -0.131 \\
Return 1/1-3/23 2020 & 127 & -0.675 & 0.204 & -1.225 & -0.260 \\
\hline
\end{tabular}

Panel B. Bank characteristics

\begin{tabular}{|c|c|c|c|c|c|}
\hline Variable & Obs. & Mean & Std. dev. & Min & Max \\
\hline Liquidity Risk & 127 & 0.209 & 0.128 & -0.453 & 0.590 \\
\hline Unused LC / Assets & 127 & 0.081 & 0.051 & 0.000 & 0.263 \\
\hline Liquidity / Assets & 127 & 0.117 & 0.079 & 0.029 & 0.513 \\
\hline Wholesale Funding / Assets & 127 & 0.132 & 0.075 & 0.013 & 0.544 \\
\hline Beta & 127 & 1.173 & 0.310 & 0.390 & 2.313 \\
\hline NPL / Loans & 127 & 0.007 & 0.007 & 0.000 & 0.044 \\
\hline Non-Interest Income & 127 & 0.227 & 0.118 & 0.005 & 0.732 \\
\hline $\log ($ Assets $)$ & 127 & 16.785 & 1.267 & 14.638 & 21.712 \\
\hline $\mathrm{ROA}$ & 127 & 0.012 & 0.003 & 0.003 & 0.020 \\
\hline Deposits / Loans & 127 & 1.124 & 0.338 & 0.756 & 4.272 \\
\hline Income Diversity & 127 & 0.445 & 0.213 & 0.010 & 0.993 \\
\hline Distance-to-Default & 127 & 3.648 & 0.522 & 1.859 & 5.060 \\
\hline Loans / Assets & 127 & 0.702 & 0.113 & 0.196 & 0.899 \\
\hline Deposits / Assets & 127 & 0.766 & 0.062 & 0.549 & 0.874 \\
\hline Idiosyncratic Volatility & 127 & 0.202 & 0.044 & 0.121 & 0.417 \\
\hline Real Estate Beta & 127 & 0.555 & 0.193 & -0.266 & 1.136 \\
\hline Primary Dealer & 127 & 0.031 & 0.175 & 0.000 & 1.000 \\
\hline Derivatives / Assets & 127 & 0.648 & 2.515 & 0.000 & 19.565 \\
\hline
\end{tabular}




\section{Table 2. Liquidity risk and bank stock returns}

This table reports the results of OLS regressions of U.S. bank' beta adjusted stock returns over the 1/1/2020 $3 / 23 / 2020$ period with different set of control variables. Panel A shows baseline results sequentially adding control variables (as described in Table 1 and defined in Appendix A). Panel B shows robustness tests adding off-balancesheet credit card exposures (column (1)), consumer loans (column (2)), exposure to the oil \& gas industry (column (3)) and other sectoral exposures (to hotel, leisure and retail industry) (column (4)) as additional control variables. Column (5) includes SRISK/Assets as additional control. All oil \& gas and sectoral exposures are based on loans reported in DealScan and thus available only for a subset of banks. SRISK is only available for banks in the vlab database. These regressions include a dummy for banks for whom we do not find exposure data (unreported). Pvalues based on robust standard errors are in parentheses. All variables are defined in Appendix II.

Panel A. Baseline results

\begin{tabular}{|c|c|c|c|c|c|}
\hline & $(1)$ & $(2)$ & $(3)$ & $(4)$ & $(5)$ \\
\hline Liquidity Risk & $\begin{array}{c}-0.363 * * * \\
(0.003)\end{array}$ & $\begin{array}{l}-0.341 * \\
(0.072)\end{array}$ & $\begin{array}{c}-0.532 * * * \\
(0.004)\end{array}$ & $\begin{array}{c}-0.526^{* *} \\
(0.010)\end{array}$ & $\begin{array}{c}-0.538 * * \\
(0.016)\end{array}$ \\
\hline Equity Beta & $\begin{array}{c}-0.266 * * * \\
(0.000)\end{array}$ & $\begin{array}{c}-0.271 * * * \\
(0.000)\end{array}$ & $\begin{array}{c}-0.165 * * \\
(0.025)\end{array}$ & $\begin{array}{l}-0.122 \\
(0.112)\end{array}$ & $\begin{array}{l}-0.123 \\
(0.113)\end{array}$ \\
\hline NPL / Loans & & $\begin{array}{c}-6.641 * * * \\
(0.001)\end{array}$ & $\begin{array}{c}-5.726 * * \\
(0.013)\end{array}$ & $\begin{array}{c}-4.728 * * \\
(0.034)\end{array}$ & $\begin{array}{c}-4.671 * * \\
(0.050)\end{array}$ \\
\hline Equity Ratio & & $\begin{array}{c}0.206 \\
(0.790)\end{array}$ & $\begin{array}{c}-0.00843 \\
(0.990)\end{array}$ & $\begin{array}{l}-1.017 \\
(0.240)\end{array}$ & $\begin{array}{l}-0.996 \\
(0.294)\end{array}$ \\
\hline Non-Interest Income & & $\begin{array}{l}0.0231 \\
(0.894)\end{array}$ & $\begin{array}{l}0.0543 \\
(0.806)\end{array}$ & $\begin{array}{c}-0.218 \\
(0.368)\end{array}$ & $\begin{array}{l}-0.212 \\
(0.405)\end{array}$ \\
\hline Log(Assets) & & $\begin{array}{c}0.00892 \\
(0.588)\end{array}$ & & $\begin{array}{c}-0.0299 * \\
(0.097)\end{array}$ & $\begin{array}{l}-0.0295 \\
(0.169)\end{array}$ \\
\hline $\mathrm{ROA}$ & & $\begin{array}{c}8.735 \\
(0.110)\end{array}$ & & $\begin{array}{l}13.56 * * \\
(0.041)\end{array}$ & $\begin{array}{l}13.41 * * \\
(0.048)\end{array}$ \\
\hline Deposits / Loans & & $\begin{array}{l}0.0262 \\
(0.594)\end{array}$ & & $\begin{array}{l}0.0289 \\
(0.631)\end{array}$ & $\begin{array}{l}0.0279 \\
(0.654)\end{array}$ \\
\hline Income Diversity & & & $\begin{array}{l}0.0106 \\
(0.942)\end{array}$ & $\begin{array}{c}0.191 \\
(0.198)\end{array}$ & $\begin{array}{c}0.189 \\
(0.217)\end{array}$ \\
\hline Distance-to-Default & & & $\begin{array}{l}0.0582 \\
(0.102)\end{array}$ & $\begin{array}{c}0.0695 * * \\
(0.045)\end{array}$ & $\begin{array}{c}0.0722 * \\
(0.052)\end{array}$ \\
\hline Loans / Assets & & & $\begin{array}{c}-0.00441 \\
(0.984)\end{array}$ & $\begin{array}{c}0.115 \\
(0.735)\end{array}$ & $\begin{array}{c}0.128 \\
(0.713)\end{array}$ \\
\hline Deposits / Assets & & & $\begin{array}{l}-0.263 \\
(0.457)\end{array}$ & $\begin{array}{c}-0.841 * * \\
(0.038)\end{array}$ & $\begin{array}{c}-0.815^{*} \\
(0.094)\end{array}$ \\
\hline Idiosyncratic Volatility & & & $\begin{array}{l}-0.741 \\
(0.139)\end{array}$ & $\begin{array}{l}-0.733 \\
(0.156)\end{array}$ & $\begin{array}{l}-0.733 \\
(0.169)\end{array}$ \\
\hline Real Estate Beta & & & $\begin{array}{c}0.00727 \\
(0.958)\end{array}$ & $\begin{array}{c}-0.00554 \\
(0.968)\end{array}$ & $\begin{array}{c}-0.00561 \\
(0.968)\end{array}$ \\
\hline Current Primary Dealer Indicator & & & & & $\begin{array}{c}-0.0652 \\
(0.677)\end{array}$ \\
\hline Derivatives / Assets & & & & & $\begin{array}{c}0.00551 \\
(0.626)\end{array}$ \\
\hline R-squared & 0.243 & 0.334 & 0.361 & 0.392 & 0.392 \\
\hline Number obs. & 127 & 127 & 127 & 127 & 127 \\
\hline
\end{tabular}


Panel B. Robustness tests

\begin{tabular}{|c|c|c|c|c|c|}
\hline & (1) & $(2)$ & (3) & (4) & (5) \\
\hline Liquidity Risk & $\begin{array}{c}-0.522 * * \\
(0.010)\end{array}$ & $\begin{array}{c}-0.542 * * \\
(0.016)\end{array}$ & $\begin{array}{l}-0.409 * \\
(0.051)\end{array}$ & $\begin{array}{l}-0.369 * \\
(0.082)\end{array}$ & $\begin{array}{c}-0.552 * * \\
(0.014)\end{array}$ \\
\hline Credit Card Commitments / Assets & $\begin{array}{c}0.616 \\
(0.120)\end{array}$ & & & & \\
\hline Consumer Loans / Assets & & $\begin{array}{l}0.0668 \\
(0.878)\end{array}$ & & & \\
\hline Oil Exposures / Assets & & & $\begin{array}{c}-2.325 * * * \\
(0.007)\end{array}$ & $\begin{array}{c}-2.001 * * * \\
(0.010)\end{array}$ & \\
\hline Other Sectoral Exposures / Assets & & & & $\begin{array}{c}-6.326^{* *} \\
(0.050)\end{array}$ & \\
\hline SRISK / Assets & & & & & $\begin{array}{c}-8.209 * * * \\
(0.005)\end{array}$ \\
\hline Controls & Yes & Yes & Yes & Yes & Yes \\
\hline R-squared & 0.423 & 0.392 & 0.399 & 0.415 & 0.444 \\
\hline Number obs. & 126 & 127 & 127 & 127 & 127 \\
\hline
\end{tabular}




\section{Table 3. Liquidity risk and bank stock returns by month}

This table reports the results of OLS regressions of U.S. bank' realized stock returns during January 2020 (columns (1)-(2), February 2020 (columns (4) to (4)) and 1-23 March 2020 (columns (5) to (6)). Regressions with control variables are based on column (5) in Panel A of Table 2. Panel B reports the results of the regression of U.S. banks' daily stock returns on Liquidity Risk interacted with natural logarithm of cumulative drawdowns from credit line by U.S. firms until this day over the $1-23$ March 2020 period. We include all firms (column (1)), the BBB-rated firms only (column (2)), then focus on non-investment grade rated firms (column (3)) and then on unrated firms (column (4)). We always include the contemporaneous return of the S\&P 500 and bank fixed effects. P-values based on robust standard errors are in parentheses. All variables are defined in Appendix II.

Panel A. Cross-sectional test

\begin{tabular}{|c|c|c|c|c|c|c|}
\hline & (1) & (2) & (3) & (4) & (5) & (6) \\
\hline & \multicolumn{2}{|c|}{ January 2020} & \multicolumn{2}{|c|}{ February 2020} & \multicolumn{2}{|c|}{$3 / 1-3 / 23 / 2020$} \\
\hline Liquidity Risk & $\begin{array}{c}-0.0254 \\
(0.231)\end{array}$ & $\begin{array}{l}-0.0521 \\
(0.208)\end{array}$ & $\begin{array}{c}-0.0001 \\
(0.997)\end{array}$ & $\begin{array}{l}-0.0138 \\
(0.739)\end{array}$ & $\begin{array}{c}-0.338 * * * \\
(0.002)\end{array}$ & $\begin{array}{c}-0.472 * * \\
(0.020)\end{array}$ \\
\hline Equity Beta & $\begin{array}{r}-0.0112 \\
(0.362)\end{array}$ & $\begin{array}{l}-0.0200 \\
(0.212)\end{array}$ & $\begin{array}{c}-0.0404 * * * \\
(0.000)\end{array}$ & $\begin{array}{c}-0.0002 \\
(0.985)\end{array}$ & $\begin{array}{c}-0.214 * * * \\
(0.002)\end{array}$ & $\begin{array}{l}-0.103 \\
(0.190)\end{array}$ \\
\hline Controls & & Yes & & Yes & & Yes \\
\hline R-squared & 0.0167 & 0.157 & 0.113 & 0.282 & 0.211 & 0.359 \\
\hline Number obs. & 127 & 127 & 127 & 127 & 127 & 127 \\
\hline
\end{tabular}

Panel B. Time-series test

\begin{tabular}{|c|c|c|c|c|}
\hline \multicolumn{5}{|c|}{ Dependent Variable: Banks' Daily Stock Returns (3/1 -3/23/2020) } \\
\hline & (1) & (2) & (3) & (4) \\
\hline Liquidity Risk x Log(Cumulative Total Drawdowns) & $\begin{array}{c}-0.007 * * \\
(0.031)\end{array}$ & & & \\
\hline Liquidity Risk x Log(Cumulative BBB Drawdowns) & & $\begin{array}{c}-0.017 * * * \\
(0.002)\end{array}$ & & \\
\hline Liquidity Risk x Log(Cumulative NonIG Drawdowns) & & & $\begin{array}{c}-0.0091 * * \\
(0.024)\end{array}$ & \\
\hline Liquidity Risk x Log(Cumulative Not Rated Drawdowns) & & & & $\begin{array}{c}-0.014 * * * \\
(0.01)\end{array}$ \\
\hline S\&P 500 & $\begin{array}{c}1.194 * * * \\
(0.000)\end{array}$ & $\begin{array}{c}1.203 * * * \\
(0.000)\end{array}$ & $\begin{array}{c}1.193 * * * \\
(0.000)\end{array}$ & $\begin{array}{c}1.193 * * * \\
(0.000)\end{array}$ \\
\hline Bank Fixed Effects & Yes & Yes & Yes & Yes \\
\hline R-squared & 0.632 & 0.630 & 0.632 & 0.630 \\
\hline Number obs. & 2595 & 2465 & 2595 & 2465 \\
\hline
\end{tabular}




\section{Table 4. Components of liquidity risk}

This table reports the results of OLS regressions of U.S. bank' beta adjusted stock returns over the 1/3/2020 $3 / 23 / 2020$ period on the different components of Liquidity Risk with control variables as in column (5) in Panel A of Table 2. We add the different components sequentially in columns (1)-(3) and add exposure to the oil \& gas industry (column (4)) and other sectoral exposures (to hotel, leisure and retail industry) as additional control variables (column (5)). We add SRISK/Assets as additional control (column (6)). All oil \& gas and sectoral exposures are based on loans reported in DealScan and thus available only for a subset of banks. SRISK is only available for banks in the vlab database. These regressions include a dummy for banks for whom we do not find exposure data (unreported). P-values based on robust standard errors are in parentheses. All variables are defined in Appendix II.

\begin{tabular}{|c|c|c|c|c|c|c|}
\hline & (1) & (2) & (3) & (4) & $(5)$ & $(6)$ \\
\hline Unused C\&I Loans / Assets & $\begin{array}{c}-1.278 * * * \\
(0.002)\end{array}$ & $\begin{array}{c}-1.308^{* * *} \\
(0.002)\end{array}$ & $\begin{array}{c}-1.383 * * * \\
(0.001)\end{array}$ & $\begin{array}{c}-1.148^{* * *} \\
(0.013)\end{array}$ & $\begin{array}{c}-1.012 * * \\
(0.043)\end{array}$ & $\begin{array}{c}-1.278 * * * \\
(0.002)\end{array}$ \\
\hline Liquidity / Assets & & $\begin{array}{c}0.284 \\
(0.376)\end{array}$ & $\begin{array}{c}0.293 \\
(0.357)\end{array}$ & $\begin{array}{c}0.204 \\
(0.541)\end{array}$ & $\begin{array}{c}0.153 \\
(0.642)\end{array}$ & $\begin{array}{c}0.347 \\
(0.273)\end{array}$ \\
\hline Wholesale Funding / Assets & & & $\begin{array}{l}-0.349 \\
(0.430)\end{array}$ & $\begin{array}{c}-0.401 \\
(0.376)\end{array}$ & $\begin{array}{c}-0.349 \\
(0.440)\end{array}$ & $\begin{array}{c}-0.290 \\
(0.462)\end{array}$ \\
\hline Equity Beta & $\begin{array}{c}-0.140 * * \\
(0.043)\end{array}$ & $\begin{array}{l}-0.135^{*} \\
(0.052)\end{array}$ & $\begin{array}{c}-0.124 * \\
(0.089)\end{array}$ & $\begin{array}{l}-0.107 \\
(0.132)\end{array}$ & $\begin{array}{l}-0.122 * \\
(0.096)\end{array}$ & $\begin{array}{l}-0.0841 \\
(0.205)\end{array}$ \\
\hline Oil Exposure & & & & $\begin{array}{c}-2.187 * * * \\
(0.009)\end{array}$ & $\begin{array}{c}-2.000 * * \\
(0.012)\end{array}$ & \\
\hline Other Sectoral Exposures & & & & & $\begin{array}{l}-4.763 \\
(0.194)\end{array}$ & \\
\hline SRISK / Assets & & & & & & $\begin{array}{c}-7.173 * * \\
(0.016)\end{array}$ \\
\hline Controls & Yes & Yes & Yes & Yes & Yes & Yes \\
\hline R-squared & 0.386 & 0.390 & 0.393 & 0.417 & 0.425 & 0.450 \\
\hline Number obs. & 127 & 127 & 127 & 127 & 127 & 127 \\
\hline
\end{tabular}




\section{Table 5. Reversal of liquidity risk}

Panel A reports descriptive statistics of bank stock returns for the months April, May and June 2020 (i.e. after the Federal Reserve Intervention on 3/23/2020). Panel B reports the results of OLS regressions of U.S. bank' realized stock returns on Liquidity Risk and its components during each of these months (columns (1) - (4)) and then for the period 3/24/2020 - 6/30/2020 (columns (5) and (6)). Control variables as in column (5) in Panel A of Table 2 are included. P-values based on robust standard errors are in parentheses. All variables are defined in Appendix II.

Panel A. Descriptive statistics of bank stock returns

\begin{tabular}{|c|c|c|c|c|c|}
\hline & Obs. & Mean & Std Dev & Min & Max \\
\hline Return April 2020 & 127 & .1140058 & .0878647 & -.0997281 & .385558 \\
\hline Return May 2020 & 127 & -.039326 & .080453 & -.4542235 & .2228914 \\
\hline Return June 2020 & 127 & .0119836 & .0528534 & -.1546759 & .1514292 \\
\hline Return 3/24-6/30/2020 & 127 & .1793604 & .1639635 & -.3437108 & 6509989 \\
\hline
\end{tabular}

Panel B. Pricing of liquidity risk

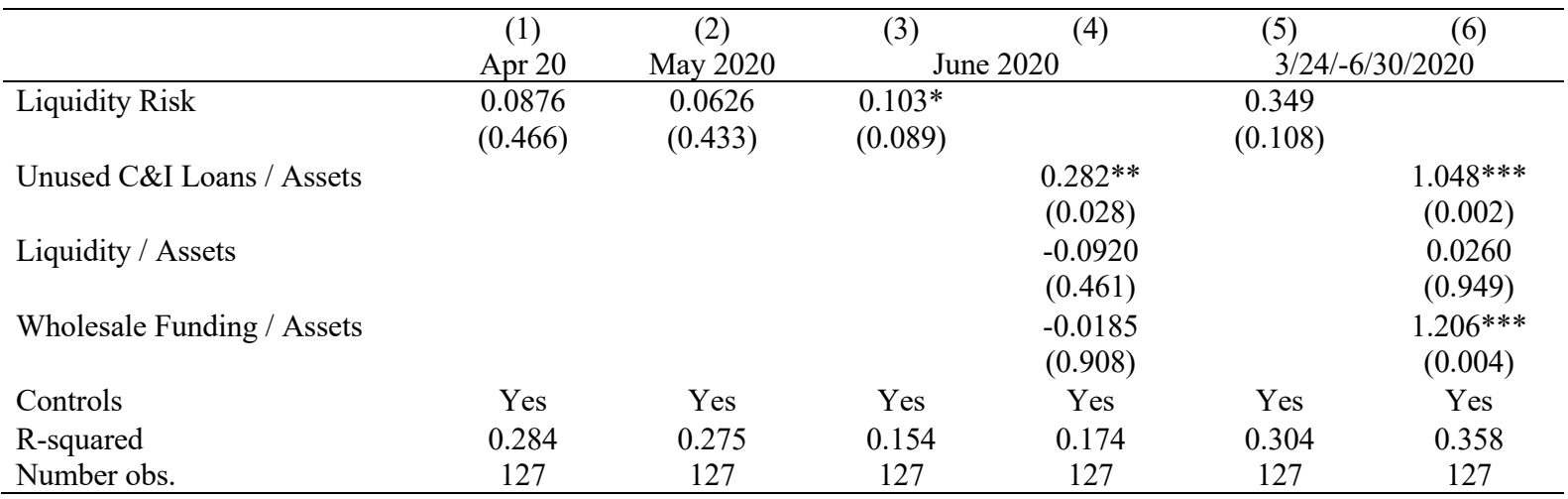


Table 6. Liquidity risk and bank stock return during the Global Financial Crisis

This table reports the results of OLS regressions of U.S. bank' realized stock returns separately for each quarter during the Q1:2007 to Q4:2009 period. We show the estimates of the coefficients of the Equity Beta of a bank with the S\&P 500 (measured monthly over the 2002-2006 period for tests in 2007 and measured monthly over the 2003-2007 period for tests in 2008/9), but include also all other control variables shown in Panel A of Table 2 (column (5)). P-values based on robust standard errors are in parentheses. All variables are defined in Appendix II.

Panel A. Liquidity risk and bank stock returns

\begin{tabular}{|c|c|c|c|c|c|c|c|c|c|}
\hline & (1) & (2) & (3) & (4) & (1) & (2) & (3) & (4) & (5) \\
\hline & Q1 2007 & Q2 2007 & Q3 2007 & Q4 2007 & Q1 2008 & Q2 2008 & Q3 2008 & Q4 2008 & Q1 2009 \\
\hline \multirow[t]{2}{*}{ Liquidity Risk } & 0.0118 & -0.00262 & $-0.0727 * *$ & $-0.153 * * *$ & $-0.160 * *$ & $-0.262 * * *$ & 0.0469 & -0.102 & -0.00628 \\
\hline & $(0.745)$ & $(0.962)$ & $(0.046)$ & $(0.002)$ & $(0.017)$ & $(0.000)$ & $(0.644)$ & $(0.386)$ & $(0.956)$ \\
\hline \multirow[t]{2}{*}{ Equity Beta } & -0.00720 & -0.0117 & 0.0114 & -0.0389 & 0.0377 & -0.0707 & 0.0299 & -0.0586 & -0.149 \\
\hline & $(0.612)$ & $(0.588)$ & $(0.439)$ & $(0.167)$ & $(0.073)$ & $(0.008)$ & $(0.336)$ & $(0.080)$ & $(0.000)$ \\
\hline Controls & Yes & Yes & Yes & Yes & Yes & Yes & Yes & Yes & Yes \\
\hline R-squared & 0.030 & 0.030 & 0.084 & 0.173 & 0.097 & 0.326 & 0.338 & 0.201 & 0.301 \\
\hline Number obs. & 225 & 225 & 225 & 225 & 237 & 237 & 237 & 237 & 237 \\
\hline
\end{tabular}

Panel B. Components of liquidity risk

\begin{tabular}{lcccc}
\hline Panel B. Components of liquidity risk & $(1)$ & $(2)$ & $(3)$ & $(4)$ \\
& Q3 2007 & Q4 2007 & Q1 2008 & Q2 2008 \\
\hline Unused C\&I Loans / Assets & $-0.222^{* *}$ & -0.0263 & $-0.360^{* * *}$ & -0.188 \\
& $(0.013)$ & $(0.864)$ & $(0.000)$ & $(0.375)$ \\
Wholesale Funding / Assets & -0.0360 & $-0.151^{* *}$ & -0.0436 & $-0.162^{*}$ \\
& $(0.519)$ & $(0.037)$ & $(0.602)$ & $(0.077)$ \\
Liquidity / Assets & 0.0678 & $0.277^{* * *}$ & 0.171 & $0.523^{* * *}$ \\
& $(0.363)$ & $(0.002)$ & $(0.125)$ & $(0.000)$ \\
Equity Beta & 0.0247 & -0.0622 & 0.0355 & -0.0779 \\
& $(0.108)$ & $(0.030)$ & $(0.087)$ & $(0.003)$ \\
Controls & Yes & Yes & Yes & Yes \\
\hline R-squared & & & 0.123 & 0.339 \\
Number obs. & 0.104 & 0.221 & 237 & 237 \\
\hline
\end{tabular}




\section{Table 7. Understanding the mechanisms: Funding versus capital}

This table reports the results of OLS regressions of U.S. bank' realized stock returns during the 1/1/2020 to 3/23/2020 period on Net Drawdowns (column (1)) and Gross Drawdowns (column (2)) and control variables. Net Drawdowns are defined as the change in a bank's off balance sheet unused C\&I loan commitments minus the change in deposits (all measured during Q1 2020) relative to total assets. Gross Drawdowns is the percentage change in a bank's off-balance sheet unused C\&I loan commitments (measured during Q1 2020). Column (4) includes an interaction term of Gross Drawdowns with Capital Buffer. Column (5) includes an interaction term of Net Drawdowns with Capital Buffer. In column (6), we use the change in bank deposits (Change Deposits) instead of Net Drawdowns. Column (7) adds SRISK/Assets as additional control. SRISK is only available for banks in the vlab database. These regressions include a dummy for banks for whom we do not find SRISK (unreported). Control variables as in column (5) in Panel A of Table 2 are included. P-values based on robust standard errors are in parentheses. All variables are defined in Appendix II.

\begin{tabular}{|c|c|c|c|c|c|c|c|}
\hline & (1) & (2) & (3) & (4) & $(5)$ & (6) & $(7)$ \\
\hline Net Drawdowns & $\begin{array}{l}0.0926 \\
(0.885)\end{array}$ & & $\begin{array}{c}0.219 \\
(0.736)\end{array}$ & $\begin{array}{c}0.128 \\
(0.844)\end{array}$ & $\begin{array}{c}0.133 \\
(0.815)\end{array}$ & & $\begin{array}{l}0.0866 \\
(0.889)\end{array}$ \\
\hline Gross Drawdowns & & $\begin{array}{c}-4.457 * * \\
(0.034)\end{array}$ & $\begin{array}{c}-4.593 * * \\
(0.023)\end{array}$ & $\begin{array}{c}-3.929 * * \\
(0.044)\end{array}$ & $\begin{array}{c}-4.485^{* *} \\
(0.026)\end{array}$ & $\begin{array}{l}-4.276^{*} \\
(0.052)\end{array}$ & $\begin{array}{c}-4.172 * * \\
(0.046)\end{array}$ \\
\hline Change Deposits / Assets & & & & & & $\begin{array}{l}-0.0697 \\
(0.904)\end{array}$ & \\
\hline Gross Drawdowns x Capital Buffer & & & & $\begin{array}{l}1.588^{*} \\
(0.084)\end{array}$ & & & \\
\hline Net Drawdowns x Capital Buffer & & & & & $\begin{array}{l}-0.109 \\
(0.688)\end{array}$ & & \\
\hline Change Deposits / Assets x Capital Buffer & & & & & & $\begin{array}{c}0.175 \\
(0.516)\end{array}$ & \\
\hline SRISK / Assets & & & & & & & $\begin{array}{c}-6.706 * \\
(0.071)\end{array}$ \\
\hline Capital Buffer & & & & $\begin{array}{c}-1.442 \\
(0.164)\end{array}$ & $\begin{array}{l}-0.759 \\
(0.415)\end{array}$ & $\begin{array}{c}-0.944 \\
(0.343)\end{array}$ & \\
\hline Controls & Yes & Yes & Yes & Yes & Yes & Yes & Yes \\
\hline R-squared & 0.353 & 0.378 & 0.379 & 0.393 & 0.381 & 0.383 & 0.424 \\
\hline Number obs. & 127 & 127 & 127 & 127 & 127 & 127 & 127 \\
\hline
\end{tabular}




\section{Table 8. Implications for bank lending during the COVID-19 pandemic}

This table provides results of difference-in-differences regressions of the change in amount/number of loan issuance pre- and post-COVID-19 on credit line drawdowns. The analysis is based on data on firm-bank-loan type level between Jan 2019 October 2020 that is collapsed to a pre- and post-COVID-19 period (post is denoted as the period starting 4/1/2020). Panel A (B) shows the results using gross (net) drawdowns. The dependent variables are the natural $\log$ of $1+$ the loan amount or the natural log of $1+$ the number of loans issued. Columns (1)-(2) controls for the demand side with borrower fixed effects; column (3) additionally controls for the supply side with borrower $\mathrm{x}$ bank fixed effects; and column (4) additionally controls for tranche type effects with borrower x bank x tranchetype fixed effects. Detailed variable definitions can be found Appendix A. Standard errors are clustered at level of the fixed effect in each column. $* * *, * * *$ denote significance at the $1 \%, 5 \%$ and $10 \%$ level, respectively. All variables are defined in Appendix II.

\section{Panel A. Loan amount}

\begin{tabular}{|c|c|c|c|c|c|}
\hline & (1) & (2) & (3) & $\begin{array}{c}(4) \\
\text { Term Loans }\end{array}$ & $\begin{array}{c}(5) \\
\text { Credit Lines } \\
\end{array}$ \\
\hline Post x Gross Drawdowns & $\begin{array}{c}-15.69^{* * *} \\
(0.001)\end{array}$ & & $\begin{array}{c}-8.651 \\
(0.117)\end{array}$ & $\begin{array}{c}-16.35^{*} \\
(0.070)\end{array}$ & $\begin{array}{c}-3.129 \\
(0.657)\end{array}$ \\
\hline Post $\mathrm{x}$ Net Drawdowns & & $\begin{array}{c}-5.676^{* * *} \\
(0.001)\end{array}$ & $\begin{array}{c}-4.267^{* *} \\
(0.028)\end{array}$ & $\begin{array}{l}-5.232 \\
(0.141)\end{array}$ & $\begin{array}{c}-4.099 * \\
(0.078)\end{array}$ \\
\hline Post & $\begin{array}{c}-2.270^{* * *} \\
(0.000)\end{array}$ & $\begin{array}{c}-2.758 * * * \\
(0.000)\end{array}$ & $\begin{array}{c}-2.544 * * * \\
(0.000)\end{array}$ & $\begin{array}{c}-2.290 * * * \\
(0.000)\end{array}$ & $\begin{array}{c}-2.710 * * * \\
(0.000)\end{array}$ \\
\hline Borrower x Bank x Loan Type FE & Yes & Yes & Yes & & \\
\hline Borrower x Bank FE & & & & Yes & Yes \\
\hline R-squared & 0.200 & 0.200 & 0.200 & 0.186 & 0.208 \\
\hline Number obs. & 17944 & 17944 & 17944 & 5770 & 12174 \\
\hline
\end{tabular}

Panel B. Number of loans

\begin{tabular}{lccccc}
\hline & $(1)$ & $(2)$ & $(3)$ & $(4)$ & $(5)$ \\
& & & Term Loans & Credit Lines \\
\hline Post x Gross Drawdowns & $-2.609^{* * *}$ & & $-1.710^{* *}$ & $-2.315^{*}$ & -1.086 \\
& $(0.000)$ & & $(0.040)$ & $(0.067)$ & $(0.323)$ \\
Post x Net Drawdowns & & $-0.824^{* * *}$ & $-0.545^{* *}$ & -0.741 & $-0.548^{*}$ \\
& & $(0.001)$ & $(0.048)$ & $(0.137)$ & $(0.098)$ \\
Post & $-0.342^{* * *}$ & $-0.419^{* * *}$ & $-0.377^{* * *}$ & $-0.315^{* * *}$ & $-0.416^{* * *}$ \\
& $(0.000)$ & $(0.000)$ & $(0.000)$ & $(0.000)$ & $(0.000)$ \\
Borrower x Bank x Loan Type FE & Yes & Yes & Yes & & Yes \\
Borrower x Bank FE & & & & 0.189 & 0.240 \\
R-squared & 0.223 & 0.223 & 0.223 & 5770 & 12174 \\
Number obs. & 17944 & 17944 & 17944 & &
\end{tabular}


Table 9. Credit line drawdowns and Incremental SRISK ${ }^{\mathrm{CL}}$

This table reports the predicted drawdown rates (Drawdown Rate) from credit lines in a stress scenario of $40 \%$ correction to the global stock market (Panel A) and the Slope of the drawdown function (compare Figure 6). In Panel B, we report the Unused Commitments (C\&I loans), and the marginal required capital to fund the predicted drawdowns (Marginal SRISK) using all three (stressed) historical drawdown rates. Incremental SRISK ${ }^{C L}=$ Drawdown rate x $8 \%$ x Unused Commitments (C\&I loans). Debt is total liabilities (from vlab). Panel C reports the calculation of Incremental SRISK ${ }^{M E S-C}$ due to the sensitivity of bank stock returns to Liquidity Risk using the minimum $\left(\gamma_{\min }\right)$ and maximum $\left(\gamma_{\max }\right)$ sensitivity from different model specifications shown in prior tables. MES$C_{\min }(\%)$ is calculated as Liquidity Risk $x \gamma_{\min } . M E S-C_{\min }(\$)$ is calculated as Liquidity Risk $x \gamma_{\min } \times M V$. Other variables are calculated accordingly. In Panel D, we show the Conditional SRISK (SRISK-C) which is the sum of Incremental SRISK ${ }^{C L}$ and Incremental SRISK ${ }^{M E S-C}$. All variables are defined in Appendix II.

Panel A. Estimating the drawdown rates in a stress scenario

\begin{tabular}{lllcc}
\hline & & Slope & $\begin{array}{c}\text { Drawdown Rate } \\
\text { (S\&P Return } \\
-40 \%)\end{array}$ \\
\hline Predicted & Quarterly & Q1 2020 & & $22.91 \%$ \\
Drawdowns & Quarterly & $2007-2009$ & -0.57 & $10.82 \%$ \\
\hline
\end{tabular}

Panel B. Incremental SRISK ${ }^{\mathrm{CL}}$

\begin{tabular}{|c|c|c|c|c|}
\hline Name & $\begin{array}{l}\text { Unused C\&I } \\
\text { Commitments } \\
\text { (USD mn) }\end{array}$ & $\begin{array}{c}\text { Drawdown } \\
\text { rate: } 10.82 \%\end{array}$ & $\begin{array}{c}\text { Drawdown } \\
\text { rate: } 22.91 \%\end{array}$ & Debt (USD mn) \\
\hline JPMORGAN CHASE \& CO. & 273,278 & 2,365 & 5,009 & $2,496,125$ \\
\hline BANK OF AMERICA CORPORATION & 310,824 & 2,690 & 5,697 & $2,158,067$ \\
\hline WELLS FARGO \& COMPANY & 198,316 & 1,717 & 3,635 & $1,748,234$ \\
\hline CITIGROUP INC. & 200,912 & 1,739 & 3,682 & $1,817,838$ \\
\hline U.S. BANCORP & 96,020 & 831 & 1,760 & 433,158 \\
\hline PNC FINANCIAL SERVICES GROUP, INC., THE & 84,238 & 729 & 1,544 & 358,342 \\
\hline M\&T BANK CORPORATION & 9,260 & 80 & 170 & 109,692 \\
\hline FIFTH THIRD BANCORP & 39,328 & 340 & 721 & 148,517 \\
\hline KEYCORP & 33,070 & 286 & 606 & 129,380 \\
\hline \multirow[t]{4}{*}{ CITIZENS FINANCIAL GROUP, INC. } & 33,682 & 292 & 617 & 142,497 \\
\hline & $1,278,928$ & 11,070 & 23,440 & $9,541,849$ \\
\hline & $1,434,367$ & 12,416 & 26,289 & $10,759,335$ \\
\hline & $1,492,916$ & 12,923 & 27,362 & \\
\hline
\end{tabular}




\begin{tabular}{|c|c|c|c|c|c|c|c|c|c|}
\hline & & & & & & & & \multicolumn{2}{|c|}{ Incremental SRISK LRMIES } \\
\hline Name & MV & LRMES & Liquidity Risk & $\gamma_{\min }$ & $\gamma_{\max }$ & LRMES $^{\text {Cmin }}$ & LRMES $^{\text {Cmax }}$ & LRMES $^{\mathrm{C}}{ }_{\text {min }}$ & LRMES $_{\text {max }}$ \\
\hline JPMORGAN CHASE \& CO. & 437,226 & $43.4 \%$ & $20.3 \%$ & -0.34 & -0.54 & $6.9 \%$ & $10.9 \%$ & 30,276 & 47,766 \\
\hline BANK OF AMERICA CORPORATION & 316,808 & $45.9 \%$ & $25.7 \%$ & -0.34 & -0.54 & $8.8 \%$ & $13.8 \%$ & 27,761 & 43,799 \\
\hline WELLS FARGO \& COMPANY & 227,540 & $44.9 \%$ & $24.2 \%$ & -0.34 & -0.54 & $8.2 \%$ & $13.0 \%$ & 18,768 & 29,610 \\
\hline CITIGROUP INC. & 174,415 & $47.3 \%$ & $37.1 \%$ & -0.34 & -0.54 & $12.6 \%$ & $19.9 \%$ & 22,047 & 34,784 \\
\hline U.S. BANCORP & 92,603 & $36.6 \%$ & $46.3 \%$ & -0.34 & -0.54 & $15.8 \%$ & $24.9 \%$ & 14,631 & 23,084 \\
\hline PNC FINANCIAL SERVICES GROUP, INC., THE & 69,945 & $40.1 \%$ & $39.9 \%$ & -0.34 & -0.54 & $13.6 \%$ & $21.5 \%$ & 9,514 & 15,011 \\
\hline M\&T BANK CORPORATION & 22,400 & $38.7 \%$ & $22.6 \%$ & -0.34 & -0.54 & $7.7 \%$ & $12.1 \%$ & 1,724 & 2,720 \\
\hline FIFTH THIRD BANCORP & 21,815 & $51.1 \%$ & $29.9 \%$ & -0.34 & -0.54 & $10.2 \%$ & $16.1 \%$ & 2,222 & 3,506 \\
\hline KEYCORP & 19,936 & $45.2 \%$ & $41.7 \%$ & -0.34 & -0.54 & $14.2 \%$ & $22.4 \%$ & 2,834 & 4,472 \\
\hline CITIZENS FINANCIAL GROUP, INC. & 17,654 & $48.3 \%$ & $46.1 \%$ & -0.34 & -0.54 & $15.7 \%$ & $24.8 \%$ & 2,772 & 4,374 \\
\hline Total (Top 10 Banks) & $1,400,341$ & & & & & & & 132,550 & 209,126 \\
\hline Total (Vlab Banks) & $1,601,754$ & & & & & & & 149,543 & 235,935 \\
\hline Total (All Sample Banks) & $1,756,619$ & & & & & & & 158,024 & 249,316 \\
\hline
\end{tabular}

\begin{tabular}{lcccc} 
Panel D. SRISK & \multicolumn{1}{l}{} \\
\hline \multicolumn{1}{c}{ SRISK (Q4 2019) } & SRISK $_{\text {min }}$ & SRISK $_{\text {max }}$ \\
Name & w/o neg & w/ neg & & \\
\hline JPMORGAN CHASE \& CO. & SRISK & SRISK & & 52,775 \\
BANK OF AMERICA CORPORATION & 0 & $-27,848$ & 32,641 & 49,496 \\
WELLS FARGO \& COMPANY & 14,898 & 14,898 & 30,452 & 33,245 \\
CITIGROUP INC. & 24,425 & 24,425 & 20,485 & 38,467 \\
U.S. BANCORP & 60,887 & 60,887 & 23,786 & 24,843 \\
PNC FINANCIAL SERVICES GROUP, INC., THE & 0 & $-19,352$ & 15,462 & 16,555 \\
M\&T BANK CORPORATION & 0 & $-9,895$ & 10,243 & 2,890 \\
FIFTH THIRD BANCORP & 0 & $-3,862$ & 1,804 & 4,227 \\
KEYCORP & 2,067 & 2,067 & 2,562 & 5,078 \\
CITIZENS FINANCIAL GROUP, INC. & 299 & 299 & 3,121 & 4,991 \\
\hline Total (Top 10 Banks) & 3,005 & 3,005 & 3,064 & 232,566 \\
Total (Vlab Banks) & 105,581 & 44,623 & 143,621 & 262,224 \\
Total (All Sample Banks) & 111,135 & 36,680 & 161,958 & 276,678 \\
\hline
\end{tabular}




\section{Appendix I. Example - Drawdowns during COVID-19}

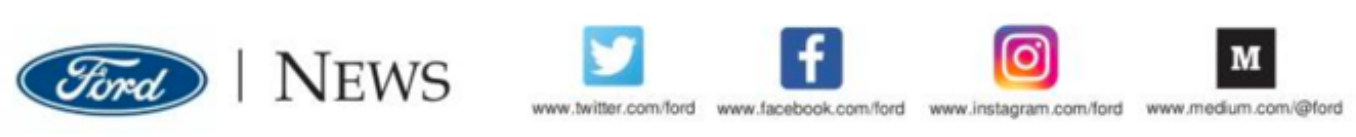

\section{Ford Takes Action to Address Effects of Coronavirus Pandemic; Company Offers New-Car Customers Six-Month Payment Relief}

- $\$ 15.4$ billion of additional cash on balance sheet, drawing from two credit lines

- Dividend suspension to preserve cash and provide additional flexibility in the current environment

- Withdrawal of company guidance for 2020 financial performance

- Three month payment deferral for eligible U.S. new-car customers, plus three more paid by Ford, for up to six months of payment peace of mind

DEARBORN, Mich., March 19, 2020 - Ford Motor Company is taking a series of initiatives to further bolster the company's cash position amid the coronavirus health crisis, maintain strategic flexibility on behalf of its team and customers, and set up Ford to separate itself from competitors when the global economy emerges from the current period of acute uncertainty.

"Like we did in the Great Recession, Ford is managing through the coronavirus crisis in a way that safeguards our business, our workforce, our customers and our dealers during this vital period," said Ford CEO Jim Hackett. "As America's largest producer of vehicles and largest employer of autoworkers, we plan to emerge from this crisis as a stronger company that can be an engine for the recovery of the economy moving forward."

The company today notified lenders that it will borrow the total unused amounts against two lines of credit: $\$ 13.4$ billion under its corporate credit facility and $\$ 2$ billion under its supplemental credit facility. The incremental cash from these borrowings will be used to offset the temporary working capital impacts of the coronavirus-related production shut downs and to preserve Ford's financial flexibility.

"While we obviously didn't foresee the coronavirus pandemic, we have maintained a strong balance sheet and ample liquidity so that we could weather economic uncertainty and continue to invest in our future," Hackett said. "Our Ford people are extremely resilient and motivated, and I'm confident in the actions we are taking to navigate the current uncertainty while continuing to build toward the future."

Ford has regularly described targets of having $\$ 20$ billion in cash and $\$ 30$ billion in liquidity heading into an economic downturn. At the end of 2019 , those levels were $\$ 22$ billion and $\$ 35$ billion, respectively.

At the same time, Ford announced it has suspended the company's dividend, prioritizing nearterm financial flexibility and continued investments in an ambitious series of new-product launches in 2020 and long-term growth initiatives.

Also, Ford said it is withdrawing the guidance it gave on Feb. 4 for 2020 financial performance, which did not factor in effects of the coronavirus, given uncertainties in the business environment. The company will provide an update on the year when it announces first-quarter results, which is currently scheduled for April 28. 


\section{Appendix II. Variable definitions}

\section{Variable name}

Assets

Capital Buffer

Consumer Loans / Assets

Credit Card Commitments / Assets

Credit Lines

Cumulative Total Drawdowns

Cumulative BBB Drawdowns

Cumulative NonIG Drawdowns

Cumulative Not Rated Drawdowns

Current Primary Dealer Indicator

\section{Debt}

Deposits / Assets

Deposits / Loans

Derivatives / Assets

Distance-to-Default

Drawdown Rate

Equity Beta

Equity Ratio

Gross Drawdowns

Idiosyncratic Volatility

Income Diversity

Incremental SRISK ${ }^{\mathrm{CL}}$

Incremental SRISK ${ }^{\text {LRMESC }}$

Liquidity

Liquidity Risk

Loan

Loans / Assets

Log(Assets)

LRMES

LRMES $^{\mathrm{C}}$

MV

Net Drawdowns

\section{Total Assets}

Difference between a bank's equity-asset ratio and the cross-sectional average of the equity-asset-ratio of all sample banks in Q4 2019

Consumer loans (\%Assets)

Unused credit card commitments (\%Assets)

Indicator if loan type within list:

Natural logarithm of the realized daily cumulative credit line drawdowns across all firms

Natural logarithm of the realized daily cumulative credit line drawdowns across all BBB-rated firms

Natural logarithm of the realized daily cumulative credit line drawdowns across all NonIG rated firms

Natural logarithm of the realized daily cumulative credit line drawdowns across all unrated firms

Indicator $=1$ if bank is current primary dealer bank (https://www.newyorkfed.org/markets/primarydealers\#primarydealers)

Market value of bank liabilities (12/31/2019)

Deposits (\%Assets)

Deposits (\%Loans)

Interest rate, exchange rat and credit derivatives (\% Assets)

Mean $(\mathrm{ROA}+\mathrm{CAR}) /$ volatility(ROA) where CAR is the capital-to-asset ratio and ROA is return on assets

Sensitivity of changes in credit line drawdowns to changes in the market returns (projected in a market downturn of $40 \%)$

Constructed using monthly data over the 2015 to 2019 period and the S\&P 500 as market index

Equity (\%Assets)

Percentage change of banks' off-balance sheet unused C\&I commitments between Q4 2019 and Q1 2020

Annualized standard deviation of the residuals from the market model

1 minus the absolute value of the ratio of the difference between net interest income and other operating income to total operating income

Equity capital that would be required to fund new loans based on banks' unused commitments $(\mathrm{CL}=$ credit lines) at the end of Q4 2019

(Marginal) equity shortfall of banks based on their end of Q4 2019 market values of equity due to effect of liquidity risk

on stock returns

The sum of cash, federal funds sold \& reverse repos, and securities excluding MBS/ABS securities.

Unused Commitments plus Wholesale Funding minus Liquidity (\% Assets)

Either natural log of loan amount or natural $\log$ of $1+$ number of loans

Total loans (\%Assets)

Natural $\log$ of Assets

LRMES is the Long Run Marginal Expected Shortfall, approximated in Acharya et al. (2012) as

$1-\mathrm{e}^{\wedge}((-18 \times \mathrm{MES}))$, where MES is the one-day loss expected in bank i's return if market returns are less than $-2 \%$

Contingent marginal expected shortfall due to the impact of liquidity risk on bank stock returns.

Market value of equity $(12 / 31 / 2019)$

Absolute change in banks' unused C\&I commitments minus the change in deposits (\% Assets) over the same period
Call Reports

Call Reports

Call Reports

Call Reports

Dealscan

8-K

8-K

$8-\mathrm{K}$

8-K

NY Fed

Vlab

Call Reports

Call Reports

Call Reports

Call Reports

Capital IQ, 8-K, CRSP

CRSP

Call Reports

Call Reports

CRSP

Call Reports

Call Reports

Call Reports

Call Reports

Call Reports

Dealscan

Call Reports

Call Reports

Call Reports

Call Reports, CRSP

Vlab

Call Reports 
Non-Interest Income

NPL / Loans

Oil Exposure / Assets

Other Sectoral Exposures / Assets Post

Real Estate Beta

Return 1/1-3/23/2020

Return January 2020 Return February 2020 Return 3/1-3/23/2020

Return April 2020

Return May 2020

Return June 2020

ROA

S\&P 500 Return

SRISK

SRISK/Assets

SRISK $^{\mathrm{C}}$

Term Loan

Unused C\&I Commitments

Unused Commitments

Wholesale Funding
Non-interest-income (\%Operating revenues)

Non-performing loans (\%Loans)

Sum of a bank's active loan exposures to oil \& gas firms (\%Assets)

Sum of a bank's active loan exposures to the retail, leisure, and hotel \& gaming industry (\%Assets)

Post is defined as the period starting April 1, 2020

Slope of the regression of weekly excess stock returns on the Fama and French real estate industry excess return in a regression that controls for the MSCI World excess return

Cumulative stock return from January 1 to March 23, 2020; $\log$ excess returns are calculated as the $\log \left(1+r-r_{f}\right)$, where

$r$ is the simple daily return (based on the daily closing price, adjusted for total return factor and daily adjustment factor), and $r_{f}$ is the 1-month daily Treasury-bill rate

Cumulative stock return from January 1 to January 31,2020

Cumulative stock return from February 1 to February 29, 2020

Cumulative stock return from March 1 to March 23, 2020

Cumulative stock return from 01.04.-30.04.2020

Cumulative stock return from $01.05-31.05 .2020$

Cumulative stock return from 01.06.-30.06.2020

Return on assets: Net Income / Assets

(Daily) excess return of the S\&P 500 index; log excess returns are calculated as the $\log \left(1+r-r_{f}\right)$, where $r$ is the simple

daily return (based on the daily closing price, adjusted for total return factor and daily adjustment factor), and $\mathrm{r}_{\mathrm{f}}$ is the 1month daily Treasury-bill rate

Bank capital shortfall in a systemic crisis as in Acharya et al. (2012)

SRISK scaled by total assets

Incremental SRISK ${ }^{\mathrm{CL}}+$ Incremental SRISK ${ }^{\text {LRMES-C }}$

Indicator if loan type within list:

Unused C\&I credit lines

The sum of credit lines secured by 1-4 family homes, secured and unsecured commercial real estate credit lines,

commitments related to securities underwriting, commercial letter of credit, and other credit lines (which includes

commitments to extend credit through overdraft facilities or commercial lines of credit)

The sum of large time deposits, deposited booked in foreign offices, subordinated debt and debentures, gross federa funds purchased, repos and other borrowed money.
Call Reports

Call Reports

Dealscan

CRSP

CRSP

CRSP

CRSP

CRSP

CRSP

CRSP

CRSP

Call Reports

CRSP

Vlab

Vlab and Call Reports

Call Reports

Dealscan

Call Reports

Call Reports

Call Reports 


\title{
Why did bank stocks crash during COVID-19?
}

\author{
Viral V. Acharya ${ }^{\dagger} \quad$ Robert Engle $\quad$ Sascha Steffen* $^{\star}$
}

March 8, 2021

\section{Online Appendix}

(Not for publication)

†NYU Stern School of Business, 44 West Fourth Street, Suite 9-10, New York, NY 10012-1126, Email: vacharya@stern.nyu.edu, Tel: +1 2129980354.

${ }^{\ddagger}$ NYU Stern School of Business, 44 West Fourth Street, Suite 9-62, New York, NY 10012-1126, Email: rengle@stern.nyu.edu, Tel: +1 2129980710.

${ }^{*}$ Frankfurt School of Finance \& Management, Adickesallee 32-34, 60323 Frankfurt, Germany, Email: s.steffen@fs.de, Tel: +49 (0)69 154008-794. 


\section{Table of Content}

\section{A Industry exposure and performance}

Figure A.1. Industry performance during COVID-19

Figure A.2. Event study around the oil price shock (9 March 2020)

B Reversal of credit line drawdowns

Table B.1 Descriptive statistics of firm's capital structure (Q4 2019 vs. Q3 2020)

Table B.2 Descriptive statistics of firm's capital structure (quarterly since Q4 2019)

Figure B.1 Preference for cash

\section{SRISK}

Table C.1 SRISK-C using only unused C\&I loans

\section{Alternative liquidity proxies}

Figure D.1. Dynamic LMI during COVID-19

Table D.1. Liquidity risk measures and pricing of drawdown options

Table D.2. Pricing of drawdown options in credit line fees

\section{E Pricing of drawdown options in credit line fees}

Table E.1. Pricing of drawdown options in credit line fees 


\section{Appendix A. Industry exposure and performance}

After the oil price shock on March 9, 2020, the market performance of the oil \& gas sector considerably deteriorated. Panel A of Figure A.1. shows the performance of this sector vis-àvis other sectors directly affected by the pandemic (i.e., retail, leisure and hotel \& gaming) using returns from loans traded in the secondary market in these sectors. While the returns in the loan market declined substantially in all sectors, loan return of oil \& gas and mining firms significantly underperformed the other sectors even after the announcement of the interventions by the Fed on March 23, 2020.

Panel B of Figure A.1. show the time-series of oil-price volatility using the CVOX oil price volatility index. While oil price volatility increases episodically during economic downturns (e.g., during the global financial crisis (GFC), i.e., the 2007 to 2009 period), the European sovereign debt crisis (2011-2012), and the oil \& gas crisis in 2015-2016), volatility has increased by more than 6 times (to over $100 \%$ on an annualized basis) around March $9^{\text {th }}$, 2020 and energy stocks crashed.

Banks are heavily exposed through loans provided to this sector. Both bank exposures and the riskiness of energy firm balance sheets have risen steadily in the recent years. We measure a bank's exposure to the oil sector using all active loans at the end of Q4:2019 and scaled by Tier 1 capital.

In addition to the tests in the main paper, we perform an event study using a 2-day window around 9 March 2020 and plot banks' 2-day beta adjusted return $\left(=r_{i}-\beta_{i} r_{S \& P}\right)^{23}$ on banks' exposure to the oil \& gas sector scaled by Tier 1 capital (Figure A.2.). We find a significant negative correlation suggesting that oil price risk is priced in bank stock returns.

\footnotetext{
${ }^{23}$ The beta is measured pre-crisis, i.e., at the end of Q4 2019.
} 


\section{Figure A1. Industry performance during COVID-19}

This figure shows the performance of some sectors during COVID-19 using different measures. In Panel A, we plot the total loan return since Jan 1, 2020 of traded in the secondary market in the following sectors: mining, oil \& gas retail, leisure, hotel \& gaming. In Panel B, we plot oil price volatility (CVOX) since July 1, 2007.

Panel A. Total loan return by industry

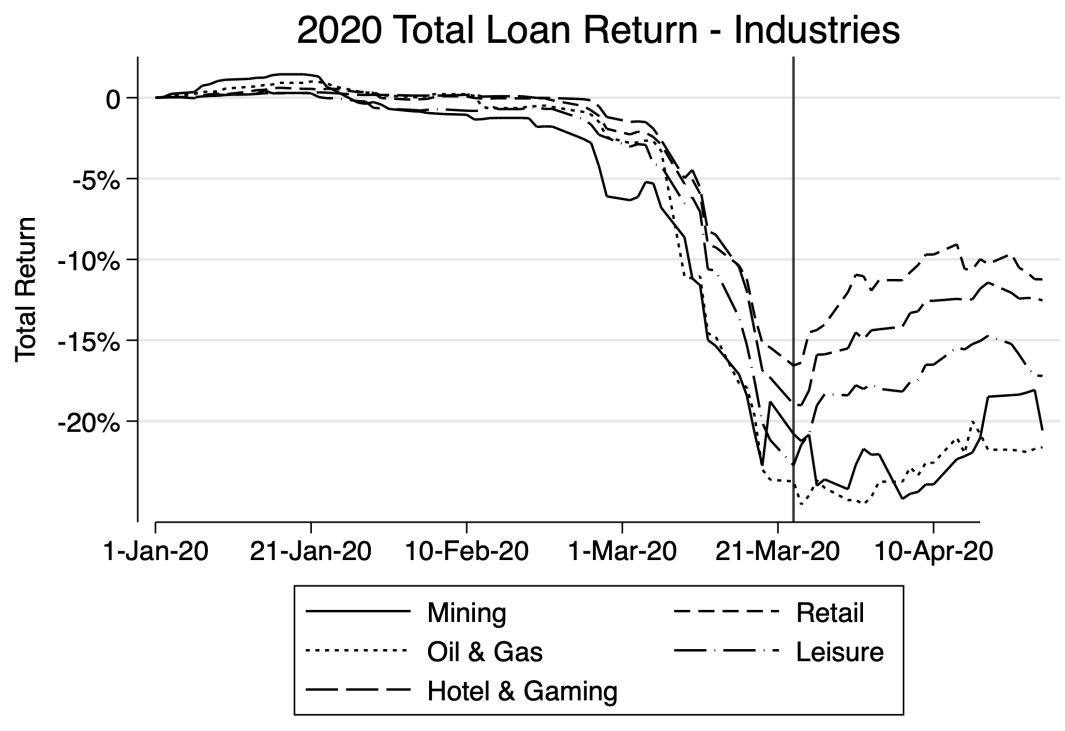

Vertical line indicates the Fed's announcement of the corporate bond buying program.

\section{Panel B. Oil price volatility}

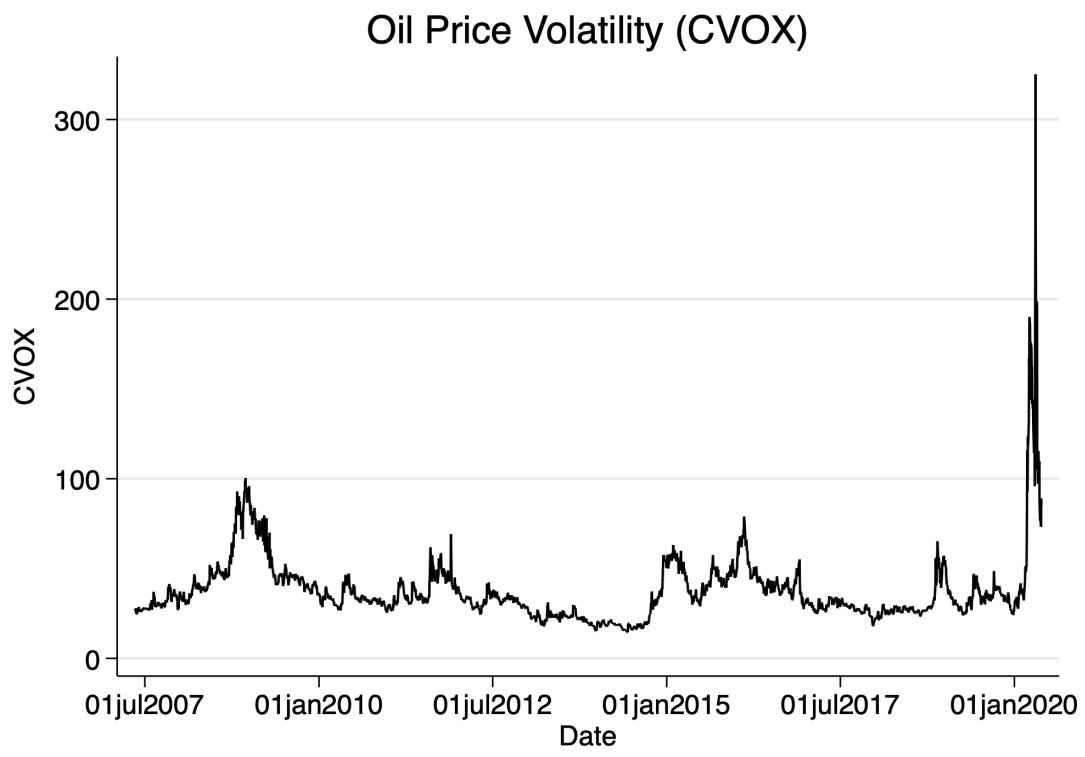


Figure A2. Event study around the oil price shock (9 March 2020)

This figure plots the 2-day beta adjusted bank stock return around the oil price shock on March 9, 2002 on banks' loan exposure to the oil \& gas industry scaled by Tier 1 capital.

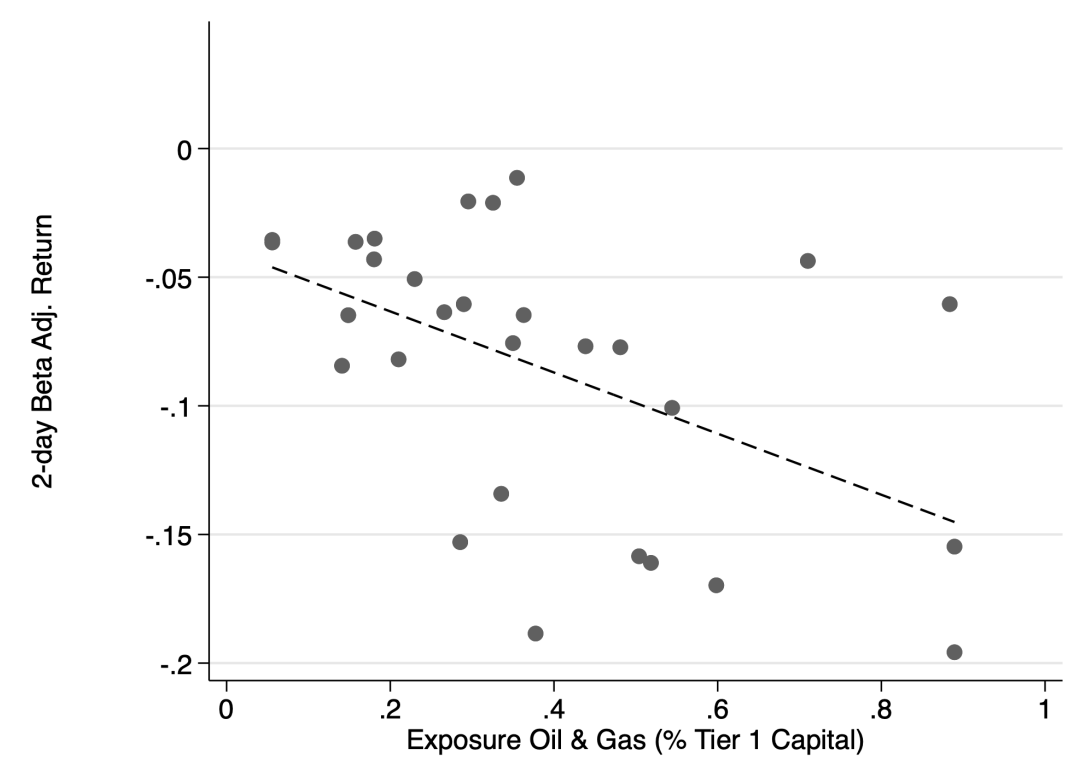




\section{Appendix B. Reversal of Credit Line Drawdowns}

To investigate the effect of credit risk on corporate cash holdings during the COVID-19 pandemic, we construct a sample of all publicly listed U.S. firms, for which financial variables are available at the end of 2019 in Capital IQ. We drop financial firms and utilities and firms with total assets below US\$100 million at the end of 2019. Our final sample comprises 1,971 U.S. nonfinancial firms. We construct the sample following Acharya and Steffen (2020).

We use quarterly debt capital structure data from CapitalIQ and investigate changes in different debt capital structure components during Q4 2019 and Q4 2020 (Table A.1) and quarterly from Q4 2019 to Q3 2020 (Table A.2). Specifically, we inspect the following: drawn credit lines (Drawn CL/Assets), credit line usage (Drawn CL/(Drawn CL + Undrawn CL)), bond debt (Bonds /Assets), term loans (Term loans/Assets), total debt (Total Debt / Assets), and preference for cash (Cash / (Cash + Undrawn CL)).

\section{B.1 Descriptive statistics of firm's capital structure (Q4 2019 vs. Q3 2020)}

\begin{tabular}{|c|c|c|c|c|}
\hline & Q4 2019 & Q3 2020 & Delta & t-stat \\
\hline \multicolumn{5}{|l|}{ A. Full sample } \\
\hline Drawn CL / (Drawn CL + Undrawn CL) & 0.188 & 0.193 & 0.005 & -1.469 \\
\hline Drawn CL / Assets & 0.036 & 0.033 & -0.003 & $2.874 * * *$ \\
\hline Bonds / Assets & 0.156 & 0.166 & 0.01 & $-4.589 * * *$ \\
\hline Term Loans / Assets & 0.078 & 0.070 & -0.008 & $4.761 * * *$ \\
\hline Total Debt / Assets & 0.344 & 0.355 & 0.011 & $-5.153 * * *$ \\
\hline Cash / (Cash + Undrawn CL) & 0.497 & 0.580 & 0.083 & $-16.892 * * *$ \\
\hline \multicolumn{5}{|l|}{ B. AAA-A rated firms } \\
\hline Drawn CL / (Drawn CL + Undrawn CL) & 0.031 & 0.027 & -0.004 & 0.394 \\
\hline Drawn CL / Assets & 0.003 & 0.002 & -0.001 & 1.445 \\
\hline Bonds / Assets & 0.299 & 0.308 & 0.009 & -0.894 \\
\hline Term Loans / Assets & 0.007 & 0.007 & 0 & 0.386 \\
\hline Total Debt / Assets & 0.349 & 0.363 & 0.014 & $-2.647 * * *$ \\
\hline Cash / (Cash + Undrawn CL) & 0.498 & 0.548 & 0.05 & $-2.723 * * *$ \\
\hline \multicolumn{5}{|l|}{ C. BBB rated firms } \\
\hline Drawn CL / (Drawn CL + Undrawn CL) & 0.072 & 0.079 & 0.007 & -0.412 \\
\hline Drawn CL / Assets & 0.011 & 0.010 & -0.001 & 0.531 \\
\hline Bonds / Assets & 0.274 & 0.290 & 0.016 & $-3.395 * * *$ \\
\hline Term Loans / Assets & 0.017 & 0.018 & 0.001 & -0.357 \\
\hline Total Debt / Assets & 0.356 & 0.372 & 0.016 & $-4.641 * * *$ \\
\hline Cash / (Cash + Undrawn CL) & 0.333 & 0.437 & 0.104 & $-8.574 * * *$ \\
\hline \multicolumn{5}{|l|}{ D. NonIG rated firms } \\
\hline Drawn CL / (Drawn CL + Undrawn CL) & 0.162 & 0.215 & 0.053 & $-3.706 * * *$ \\
\hline Drawn CL / Assets & 0.033 & 0.036 & 0.003 & -1.57 \\
\hline Bonds / Assets & 0.235 & 0.246 & 0.011 & $-2.042 * *$ \\
\hline Term Loans / Assets & 0.142 & 0.132 & -0.01 & $3.264 * * *$ \\
\hline Total Debt / Assets & 0.482 & 0.499 & 0.017 & $-3.861 * * *$ \\
\hline Cash / (Cash + Undrawn CL) & 0.363 & 0.482 & 0.119 & $-10.894 * * *$ \\
\hline \multicolumn{5}{|l|}{ E. Unrated firms } \\
\hline Drawn CL / (Drawn CL + Undrawn CL) & 0.259 & 0.237 & -0.022 & 1.303 \\
\hline Drawn CL / Assets & 0.046 & 0.040 & -0.006 & $4.227 * * *$ \\
\hline Bonds / Assets & 0.080 & 0.089 & 0.009 & $-3.139 * * *$ \\
\hline Term Loans / Assets & 0.070 & 0.061 & -0.009 & $3.775 * * *$ \\
\hline Total Debt / Assets & 0.280 & 0.286 & 0.006 & $-2.241 * *$ \\
\hline Cash / (Cash + Undrawn CL) & 0.592 & 0.658 & 0.066 & $-10.344 * * *$ \\
\hline
\end{tabular}


Table B.2. Descriptive statistics of firm's capital structure (Q4 2019 to Q3 2020)

Panel A. Full sample

\begin{tabular}{|c|c|c|c|c|}
\hline Variable & Mean & Std dev & Min & Max \\
\hline Drawn CL / (Drawn CL + Undrawn CL) - Q4 2019 & 0.188 & 0.269 & 0.000 & 1.000 \\
\hline Drawn CL / (Drawn CL + Undrawn CL) - Q1 2020 & 0.381 & 0.353 & 0.000 & 1.000 \\
\hline Drawn CL / (Drawn CL + Undrawn CL) - Q2 2020 & 0.277 & 0.332 & 0.000 & 1.000 \\
\hline Drawn CL / (Drawn CL + Undrawn CL) - Q3 2020 & 0.193 & 0.288 & 0.000 & 1.000 \\
\hline Drawn CL / Assets - Q4 2019 & 0.036 & 0.073 & 0.000 & 0.355 \\
\hline Drawn CL / Assets - Q1 2020 & 0.058 & 0.086 & 0.000 & 0.400 \\
\hline Drawn CL / Assets - Q2 2020 & 0.046 & 0.081 & 0.000 & 0.396 \\
\hline Drawn CL / Assets - Q3 2020 & 0.033 & 0.069 & 0.000 & 0.340 \\
\hline Bonds / Assets - Q4 2019 & 0.156 & 0.192 & 0.000 & 0.909 \\
\hline Bonds / Assets - Q1 2020 & 0.158 & 0.194 & 0.000 & 0.923 \\
\hline Bonds / Assets - Q2 2020 & 0.167 & 0.198 & 0.000 & 0.873 \\
\hline Bonds / Assets - Q3 2020 & 0.166 & 0.198 & 0.000 & 0.855 \\
\hline Term Loans / Assets - Q4 2019 & 0.078 & 0.134 & 0.000 & 0.645 \\
\hline Term Loans / Assets - Q1 2020 & 0.078 & 0.132 & 0.000 & 0.617 \\
\hline Term Loans / Assets - Q2 2020 & 0.078 & 0.131 & 0.000 & 0.598 \\
\hline Term Loans / Assets - Q3 2020 & 0.070 & 0.124 & 0.000 & 0.565 \\
\hline Total Debt / Assets - Q4 2019 & 0.344 & 0.229 & 0.002 & 1.134 \\
\hline Total Debt / Assets - Q1 2020 & 0.370 & 0.240 & 0.002 & 1.180 \\
\hline Total Debt / Assets - Q2 2020 & 0.368 & 0.243 & 0.002 & 1.242 \\
\hline Total Debt / Assets - Q3 2020 & 0.355 & 0.241 & 0.002 & 1.228 \\
\hline Cash / (Cash + Undrawn CL) - Q4 2019 & 0.497 & 0.344 & 0.002 & 1.000 \\
\hline Cash / (Cash + Undrawn CL) - Q1 2020 & 0.608 & 0.333 & 0.005 & 1.000 \\
\hline Cash / (Cash + Undrawn CL) - Q2 2020 & 0.593 & 0.329 & 0.004 & 1.000 \\
\hline Cash / (Cash + Undrawn CL) - Q3 2020 & 0.580 & 0.331 & 0.006 & 1.000 \\
\hline
\end{tabular}

Panel B. AAA-A rated firms

\begin{tabular}{|c|c|c|c|c|}
\hline Variable & Mean & Std dev & Min & Max \\
\hline Drawn CL / (Drawn CL + Undrawn CL) - Q4 2019 & 0.031 & 0.113 & 0.000 & 0.911 \\
\hline Drawn CL / (Drawn CL + Undrawn CL) - Q1 2020 & 0.156 & 0.290 & 0.000 & 1.000 \\
\hline Drawn CL / (Drawn CL + Undrawn CL) - Q2 2020 & 0.069 & 0.195 & 0.000 & 0.958 \\
\hline Drawn CL / (Drawn CL + Undrawn CL) - Q3 2020 & 0.027 & 0.085 & 0.000 & 0.445 \\
\hline Drawn CL / Assets - Q4 2019 & 0.003 & 0.014 & 0.000 & 0.125 \\
\hline Drawn CL / Assets - Q1 2020 & 0.013 & 0.028 & 0.000 & 0.142 \\
\hline Drawn CL / Assets - Q2 2020 & 0.007 & 0.023 & 0.000 & 0.147 \\
\hline Drawn CL / Assets - Q3 2020 & 0.002 & 0.008 & 0.000 & 0.053 \\
\hline Bonds / Assets - Q4 2019 & 0.299 & 0.154 & 0.000 & 0.754 \\
\hline Bonds / Assets - Q1 2020 & 0.308 & 0.151 & 0.000 & 0.781 \\
\hline Bonds / Assets - Q2 2020 & 0.319 & 0.138 & 0.011 & 0.779 \\
\hline Bonds / Assets - Q3 2020 & 0.308 & 0.133 & 0.000 & 0.770 \\
\hline Term Loans / Assets - Q4 2019 & 0.007 & 0.017 & 0.000 & 0.108 \\
\hline Term Loans / Assets - Q1 2020 & 0.008 & 0.019 & 0.000 & 0.145 \\
\hline Term Loans / Assets - Q2 2020 & 0.007 & 0.013 & 0.000 & 0.058 \\
\hline Term Loans / Assets - Q3 2020 & 0.007 & 0.013 & 0.000 & 0.060 \\
\hline Total Debt / Assets - Q4 2019 & 0.349 & 0.145 & 0.046 & 0.753 \\
\hline Total Debt / Assets - Q1 2020 & 0.369 & 0.147 & 0.045 & 0.757 \\
\hline Total Debt / Assets - Q2 2020 & 0.376 & 0.135 & 0.062 & 0.757 \\
\hline Total Debt / Assets - Q3 2020 & 0.363 & 0.130 & 0.057 & 0.754 \\
\hline Cash / (Cash + Undrawn CL) - Q4 2019 & 0.498 & 0.322 & 0.002 & 1.000 \\
\hline Cash / (Cash + Undrawn CL) - Q1 2020 & 0.585 & 0.308 & 0.005 & 1.000 \\
\hline Cash / (Cash + Undrawn CL) - Q2 2020 & 0.564 & 0.296 & 0.004 & 1.000 \\
\hline Cash / (Cash + Undrawn CL) - Q3 2020 & 0.548 & 0.304 & 0.006 & 1.000 \\
\hline
\end{tabular}


Panel C. BBB rated firms

\begin{tabular}{|c|c|c|c|c|}
\hline Variable & Mean & Std dev & Min & Max \\
\hline Drawn CL / (Drawn CL + Undrawn CL) - Q4 2019 & 0.072 & 0.165 & 0.000 & 1.000 \\
\hline Drawn CL / (Drawn CL + Undrawn CL) - Q1 2020 & 0.235 & 0.285 & 0.000 & 1.000 \\
\hline Drawn CL / (Drawn CL + Undrawn CL) - Q2 2020 & 0.129 & 0.241 & 0.000 & 1.000 \\
\hline Drawn CL / (Drawn CL + Undrawn CL) - Q3 2020 & 0.079 & 0.182 & 0.000 & 1.000 \\
\hline Drawn CL / Assets - Q4 2019 & 0.011 & 0.039 & 0.000 & 0.344 \\
\hline Drawn CL / Assets - Q1 2020 & 0.030 & 0.053 & 0.000 & 0.400 \\
\hline Drawn CL / Assets - Q2 2020 & 0.019 & 0.046 & 0.000 & 0.396 \\
\hline Drawn CL / Assets - Q3 2020 & 0.010 & 0.026 & 0.000 & 0.240 \\
\hline Bonds / Assets - Q4 2019 & 0.274 & 0.136 & 0.000 & 0.909 \\
\hline Bonds / Assets - Q1 2020 & 0.279 & 0.138 & 0.000 & 0.923 \\
\hline Bonds / Assets - Q2 2020 & 0.292 & 0.141 & 0.000 & 0.873 \\
\hline Bonds / Assets - Q3 2020 & 0.290 & 0.146 & 0.000 & 0.855 \\
\hline Term Loans / Assets - Q4 2019 & 0.017 & 0.035 & 0.000 & 0.203 \\
\hline Term Loans / Assets - Q1 2020 & 0.022 & 0.042 & 0.000 & 0.286 \\
\hline Term Loans / Assets - Q2 2020 & 0.021 & 0.038 & 0.000 & 0.221 \\
\hline Term Loans / Assets - Q3 2020 & 0.018 & 0.036 & 0.000 & 0.232 \\
\hline Total Debt / Assets - Q4 2019 & 0.356 & 0.145 & 0.048 & 1.001 \\
\hline Total Debt / Assets - Q1 2020 & 0.381 & 0.148 & 0.075 & 1.034 \\
\hline Total Debt / Assets - Q2 2020 & 0.382 & 0.148 & 0.064 & 1.040 \\
\hline Total Debt / Assets - Q3 2020 & 0.372 & 0.145 & 0.054 & 1.017 \\
\hline Cash / (Cash + Undrawn CL) - Q4 2019 & 0.333 & 0.254 & 0.002 & 1.000 \\
\hline Cash / (Cash + Undrawn CL) - Q1 2020 & 0.439 & 0.269 & 0.015 & 1.000 \\
\hline Cash / (Cash + Undrawn CL) - Q2 2020 & 0.446 & 0.267 & 0.004 & 1.000 \\
\hline Cash / (Cash + Undrawn CL) - Q3 2020 & 0.437 & 0.268 & 0.006 & 1.000 \\
\hline \multicolumn{5}{|l|}{ Panel D. NonIG rated firms } \\
\hline Variable & Mean & Std dev & Min & Max \\
\hline Drawn CL / (Drawn CL + Undrawn CL) - Q4 2019 & 0.162 & 0.241 & 0.000 & 1.000 \\
\hline Drawn CL / (Drawn CL + Undrawn CL) - Q1 2020 & 0.443 & 0.353 & 0.000 & 1.000 \\
\hline Drawn CL / (Drawn CL + Undrawn CL) - Q2 2020 & 0.310 & 0.335 & 0.000 & 1.000 \\
\hline Drawn CL / (Drawn CL + Undrawn CL) - Q3 2020 & 0.215 & 0.301 & 0.000 & 1.000 \\
\hline Drawn CL / Assets - Q4 2019 n & 0.033 & 0.066 & 0.000 & 0.355 \\
\hline Drawn CL / Assets - Q1 2020 & 0.067 & 0.078 & 0.000 & 0.400 \\
\hline Drawn CL / Assets - Q2 2020 & 0.048 & 0.071 & 0.000 & 0.396 \\
\hline Drawn CL / Assets - Q3 2020 & 0.036 & 0.068 & 0.000 & 0.340 \\
\hline Bonds / Assets - Q4 2019 & 0.235 & 0.187 & 0.000 & 0.909 \\
\hline Bonds / Assets - Q1 2020 & 0.236 & 0.190 & 0.000 & 0.923 \\
\hline Bonds / Assets - Q2 2020 & 0.252 & 0.199 & 0.000 & 0.873 \\
\hline Bonds / Assets - Q3 2020 & 0.246 & 0.199 & 0.000 & 0.855 \\
\hline Term Loans / Assets - Q4 2019 & 0.142 & 0.157 & 0.000 & 0.645 \\
\hline Term Loans / Assets - Q1 2020 & 0.141 & 0.157 & 0.000 & 0.617 \\
\hline Term Loans / Assets - Q2 2020 & 0.141 & 0.156 & 0.000 & 0.598 \\
\hline Term Loans / Assets - Q3 2020 & 0.132 & 0.150 & 0.000 & 0.565 \\
\hline Total Debt / Assets - Q4 2019 & 0.482 & 0.198 & 0.051 & 1.134 \\
\hline Total Debt / Assets - Q1 2020 & 0.518 & 0.205 & 0.059 & 1.180 \\
\hline Total Debt / Assets - Q2 2020 & 0.518 & 0.215 & 0.058 & 1.242 \\
\hline Total Debt / Assets - Q3 2020 & 0.499 & 0.217 & 0.053 & 1.228 \\
\hline Cash / (Cash + Undrawn CL) - Q4 2019 & 0.363 & 0.263 & 0.002 & 1.000 \\
\hline Cash / (Cash + Undrawn CL) - Q1 2020 & 0.540 & 0.320 & 0.005 & 1.000 \\
\hline Cash / (Cash + Undrawn CL) - Q2 2020 & 0.500 & 0.311 & 0.004 & 1.000 \\
\hline Cash / (Cash + Undrawn CL) - Q3 2020 & 0.482 & 0.302 & 0.006 & 1.000 \\
\hline
\end{tabular}


Panel E. Unrated firms

\begin{tabular}{|c|c|c|c|c|}
\hline Variable & Mean & Std dev & Min & Max \\
\hline Drawn CL / (Drawn CL + Undrawn CL) - Q4 2019 & 0.259 & 0.300 & 0.000 & 1.000 \\
\hline Drawn CL / (Drawn CL + Undrawn CL) - Q1 2020 & 0.415 & 0.356 & 0.000 & 1.000 \\
\hline Drawn CL / (Drawn CL + Undrawn CL) - Q2 2020 & 0.329 & 0.345 & 0.000 & 1.000 \\
\hline Drawn CL / (Drawn CL + Undrawn CL) - Q3 2020 & 0.237 & 0.307 & 0.000 & 1.000 \\
\hline Drawn CL / Assets - Q4 2019 & 0.046 & 0.083 & 0.000 & 0.355 \\
\hline Drawn CL / Assets - Q1 2020 & 0.065 & 0.096 & 0.000 & 0.400 \\
\hline Drawn CL / Assets - Q2 2020 & 0.055 & 0.091 & 0.000 & 0.396 \\
\hline Drawn CL / Assets - Q3 2020 & 0.040 & 0.078 & 0.000 & 0.340 \\
\hline Bonds / Assets - Q4 2019 & 0.080 & 0.171 & 0.000 & 0.909 \\
\hline Bonds / Assets - Q1 2020 & 0.082 & 0.172 & 0.000 & 0.923 \\
\hline Bonds / Assets - Q2 2020 & 0.087 & 0.175 & 0.000 & 0.873 \\
\hline Bonds / Assets - Q3 2020 & 0.089 & 0.176 & 0.000 & 0.855 \\
\hline Term Loans / Assets - Q4 2019 & 0.070 & 0.132 & 0.000 & 0.645 \\
\hline Term Loans / Assets - Q1 2020 & 0.069 & 0.129 & 0.000 & 0.617 \\
\hline Term Loans / Assets - Q2 2020 & 0.070 & 0.127 & 0.000 & 0.598 \\
\hline Term Loans / Assets - Q3 2020 & 0.061 & 0.119 & 0.000 & 0.565 \\
\hline Total Debt / Assets - Q4 2019 & 0.280 & 0.236 & 0.002 & 1.134 \\
\hline Total Debt / Assets - Q1 2020 & 0.303 & 0.248 & 0.002 & 1.180 \\
\hline Total Debt / Assets - Q2 2020 & 0.299 & 0.250 & 0.002 & 1.242 \\
\hline Total Debt / Assets - Q3 2020 & 0.286 & 0.248 & 0.002 & 1.228 \\
\hline Cash / (Cash + Undrawn CL) - Q4 2019 & 0.592 & 0.362 & 0.002 & 1.000 \\
\hline Cash / (Cash + Undrawn CL) - Q1 2020 & 0.677 & 0.334 & 0.005 & 1.000 \\
\hline Cash / (Cash + Undrawn CL) - Q2 2020 & 0.670 & 0.331 & 0.004 & 1.000 \\
\hline Cash / (Cash + Undrawn CL) - Q3 2020 & 0.658 & 0.337 & 0.006 & 1.000 \\
\hline
\end{tabular}




\section{Figure B.1. Preference for cash}

This figure shows the median Cash / (Cash + Undrawn CL) ratio (panel B) of U.S. nonfinancial firms over the Q1 2018 to Q3 2020 period.

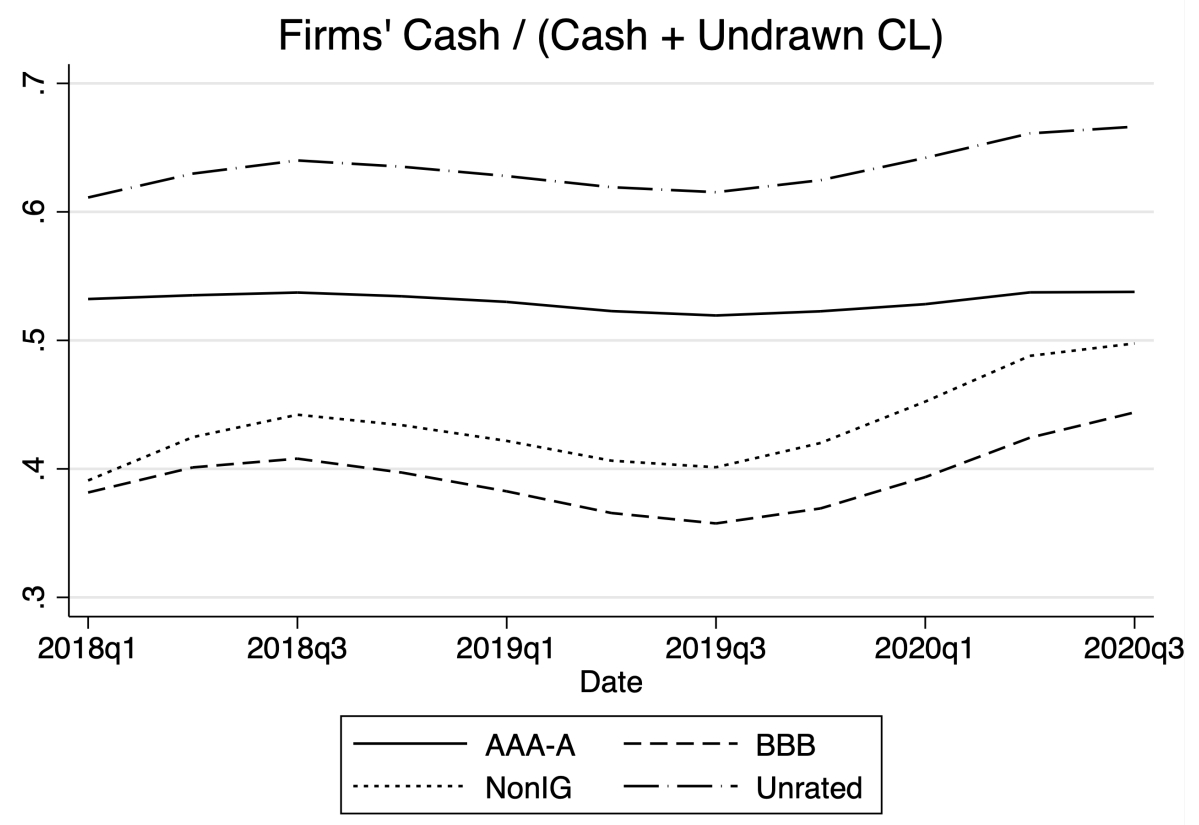

Preference for cash has increased / remained high during the 3 quarters in 2020, particularly of lower rated and unrated firms. 


\section{Appendix C - SRISK-C using only unused C\&I loans}

In Online Appendix C, we calculate SRISK-C but use only unused C\&I loans (and the estimated coffients) . Everything else is as in Table 9 of the main paper. 


\section{Table B.1 Incremental SRISK ${ }^{\text {LRMES-C }}$}

Panel A reports the calculation of Incremental SRISK ${ }^{\text {MES-C }}$ due to the sensitivity of bank stock returns to Unused C\&I Credit Lines using the minimum ( $\left.\gamma_{\min }\right)$ and maximum ( $\left.\gamma_{\max }\right)$ sensitivity from different model specifications shown in prior tables. MES-C $C_{\min }(\%)$ is calculated as Liquidity Risk $x \gamma_{\min } . M E S$ - $C_{\min }(\$)$ is calculated as Liquidity Risk $x \gamma_{\min } x$ MV $_{\text {. }}$ Other variables are calculated accordingly. In Panel B, we show the Conditional SRISK (SRISK-C) which is the sum of Incremental SRISK ${ }^{C L}$ and Incremental SRISK ${ }^{M E S-C}$. All variables are defined in Appendix I.

\begin{tabular}{|c|c|c|c|c|c|c|c|c|c|}
\hline & \multirow[b]{2}{*}{ MV } & \multirow[b]{2}{*}{ LRMES } & \multirow[b]{2}{*}{ Liquidity Risk } & \multirow[b]{2}{*}{$\gamma_{\min }$} & \multirow[b]{2}{*}{$\gamma_{\max }$} & \multirow[b]{2}{*}{ LRMES- $\mathrm{C}_{\min }$} & \multicolumn{3}{|c|}{ Incremental SRISK $^{\text {LRMES-C }}$} \\
\hline & & & & & & & LRMES- $\mathrm{C}_{\max }$ & LRMES- $\mathrm{C}_{\min }$ & LRMES- $C_{\max }$ \\
\hline JPMORGAN CHASE \& CO. & 437,226 & $43.4 \%$ & $20.3 \%$ & -1.012 & -1.383 & $10.3 \%$ & $14.1 \%$ & 44,995 & 61,490 \\
\hline BANK OF AMERICA CORPORATION & 316,808 & $45.9 \%$ & $25.7 \%$ & -1.012 & -1.383 & $12.9 \%$ & $17.7 \%$ & 40,941 & 55,950 \\
\hline WELLS FARGO \& COMPANY & 227,540 & $44.9 \%$ & $24.2 \%$ & -1.012 & -1.383 & $10.4 \%$ & $14.2 \%$ & 23,691 & 32,377 \\
\hline CITIGROUP INC. & 174,415 & $47.3 \%$ & $37.1 \%$ & -1.012 & -1.383 & $10.4 \%$ & $14.2 \%$ & 18,175 & 24,838 \\
\hline U.S. BANCORP & 92,603 & $36.6 \%$ & $46.3 \%$ & -1.012 & -1.383 & $19.6 \%$ & $26.8 \%$ & 18,163 & 24,822 \\
\hline PNC FINANCIAL SERVICES GROUP, INC., THE & 69,945 & $40.1 \%$ & $39.9 \%$ & -1.012 & -1.383 & $20.8 \%$ & $28.4 \%$ & 14,530 & 19,857 \\
\hline M\&T BANK CORPORATION & 22,400 & $38.7 \%$ & $22.6 \%$ & -1.012 & -1.383 & $7.8 \%$ & $10.7 \%$ & 1,751 & 2,393 \\
\hline FIFTH THIRD BANCORP & 21,815 & $51.1 \%$ & $29.9 \%$ & -1.012 & -1.383 & $23.5 \%$ & $32.1 \%$ & 5,126 & 7,006 \\
\hline KEYCORP & 19,936 & $45.2 \%$ & $41.7 \%$ & -1.012 & -1.383 & $23.0 \%$ & $31.4 \%$ & 4,583 & 6,264 \\
\hline CITIZENS FINANCIAL GROUP, INC. & 17,654 & $48.3 \%$ & $46.1 \%$ & -1.012 & -1.383 & $20.5 \%$ & $28.0 \%$ & 3,623 & 4,951 \\
\hline Total (Top 10 Banks) & $1,400,341$ & & & & & & & 175,579 & 239,946 \\
\hline Total (Vlab Banks) & $1,601,754$ & & & & & & & 197,984 & 270,565 \\
\hline Total (All Sample Banks) & $1,756,619$ & & & & & & & 207,978 & 284,223 \\
\hline
\end{tabular}


Panel B. SRISK-C

\begin{tabular}{lcccc}
\hline Name & \multicolumn{2}{c}{ SRISK (Q4 2019) } & SRISK-C $_{\min }$ & SRISK-C $_{\max }$ \\
& w/o neg & w/ neg & & \\
\hline JPMORGAN CHASE \& CO. & SRISK & SRISK & & 73,392 \\
BANK OF AMERICA CORPORATION & 0 & $-27,848$ & 51,604 & 69,487 \\
WELLS FARGO \& COMPANY & 14,898 & 14,898 & 48,458 & 41,014 \\
CITIGROUP INC. & 24,425 & 24,425 & 28,487 & 33,588 \\
U.S. BANCORP & 60,887 & 60,887 & 23,034 & 29,003 \\
PNC FINANCIAL SERVICES GROUP, INC., THE & 0 & $-19,352$ & 20,485 & 23,525 \\
M\&T BANK CORPORATION & 0 & $-9,895$ & 16,567 & 2,796 \\
FIFTH THIRD BANCORP & 0 & $-3,862$ & 1,975 & 8,718 \\
KEYCORP & 2,067 & 2,067 & 6,077 & 7,704 \\
CITIZENS FINANCIAL GROUP, INC. & 299 & 299 & 5,383 & 6,418 \\
\hline Total (Top 10 Banks) & 3,005 & 3,005 & 4,438 & 295,646 \\
Total (Vlab Banks) & 105,581 & 44,623 & 206,508 & 333,034 \\
Total (All Sample Banks) & 111,135 & 36,680 & 232,673 & 349,243 \\
\hline
\end{tabular}




\section{Appendix D - Discussion}

Finally, we discuss the robustness of our results and its extensions along several dimensions in section 8 in the main body of the paper. (1) Alternative liquidity proxies used in the literature; (2) pricing of contingent drawdown options through credit line fees; (3) the role of covenants during the pandemic; and (4) repayment of credit lines after fiscal and monetary interventions.

\section{D.1. Constructing our liquidity proxies}

In Online Appendix D.1, we discuss provide a more extensive discussion of the different liquidity proxies used in the literature.

\section{A. Berger and Bouwman (2009) liquidity creation measure}

To replicate the Berger-Bouwman (2009) measure on liquidity creation using FR Y-9C data, we apply the data mapping available in Berger et al. (2020). ${ }^{24}$ Individual on- and off-balance sheet items are aggregated and weighted in line with the classification provided by Berger \& Bouwman (2009). Finally, the weighted positions are combined to the aggregate liquidity creation measure for each bank holding company. Note that we only replicate Berger \& Bouwman's so-called "catfat" measure, which is constructed by classifying balance sheet items by category (see Berger \& Bouwman, 2009) and includes on- as well as off-balance sheet positions.

\section{B. Bai et al. (2018) liquidity risk measure (LMI)}

To construct the Bai et al. (2018) liquidity mismatch index (LMI), we use information provided in the paper's Online Appendix together with the FR Y-9C call report template for 2019Q4 to map all balance sheet items, except deposits, to the variables in our dataset. The deposit data is constructed in line with the approach outlined in Bai et al. (2018), using FFIEC 031 call report data for commercial banks aggregated for the respective parent bank holding company. ${ }^{25}$

\footnotetext{
${ }^{24}$ Berger, A.N., C.H.S. Bouwman, B. Imbierowicz and C. Rauch (2020), How are banks special? - Let me count the ways.

${ }^{25}$ We thank Jennie Bai for detailed guidance how to construct their measure.
} 
Commercial banks and bank holding companies are matched with the help of the FSSD's relationship table. We consider a bank holding company to be a commercial bank's parent, if their relationship exists at least until 31 December 2019.

In the next step, we calculate the asset and liability weights per category as indicated in Bai et al. (2018) using the parameters and estimates provided by the authors. Accordingly, haircut values as well as the magnitude of the Frist Principal Component used in constructing our measure are averages taken from Bai et al. (2018). As described in the main text of the paper, we use two different proxies for the liquidity premium $\mu_{\mathrm{t}}$, which is defined as the OIS 3m Treasury Bill spread. We create two LMIs, one using liquidity conditions as of Q4 2019 (LMI - 2019) and one using the worst liquidity condition in March 2020 (LMI-2020). We weigh the aggregate positions with the respective asset/liability weight to calculate the liquidity risk measure per bank holding company.

Both LMI measures are constructed as of Q4 2019. We also construct a time-series LMI measure using a daily adjusting liquidity weight. We plot the time-series in Figure D.1. below. Liquidity risk increases significantly in March 2020 within a few days and then returned almost to a pre-COVID-19 level when monetary and fiscal policy measures have been implemented. 
Figure D.1. Dynamic LMI during COVID-19

Figure D.1. plots the times-series LMI measure using a daily adjusted OIS-3m Treasury spread measure as liquidity weight.

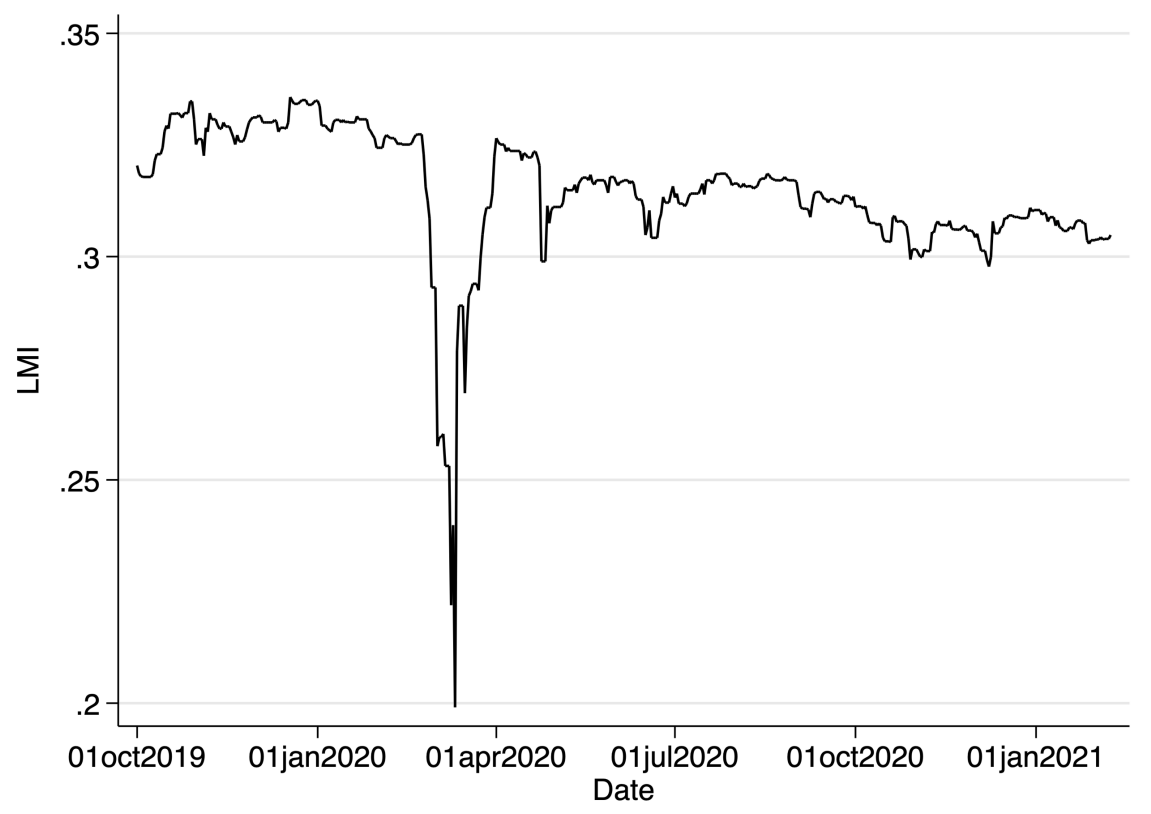




\section{Table D1. Liquidity risk measures and pricing of drawdown options}

This tables shows descriptive statistics of different liquidity measures (Panel A) and the results of OLS regressions of U.S. bank' beta adjusted stock returns over the 1/1/2020 -3/23/2020 period using these liquidity measures and control variables. These are the liquidity measures: Liquidity Risk (Unused Commitments plus Wholesale Funding minus Liquidity (\% Assets)); Unused C\&I Loans / Assets are Unused C\&I credit lines over total assets; BB is the Berger and Bouwman (2009) "catfat" measure; LMI-2019 is Bai et al (2019) liquidity measure using liquidity conditions as of Q4 2019; LMI - 2020 is the Bai et al. (2018) liquidity measure using the worst liquidity condition in March 2020.

Panel A. Descriptive statistics

\begin{tabular}{|c|c|c|c|c|c|}
\hline Variable & Obs & Mean & Std. Dev & Min & Max \\
\hline Liquidity Risk & 127 & 0.209 & 0.128 & -0.453 & 0.590 \\
\hline Unused C\&I Loans / Assets & 127 & 0.081 & 0.051 & 0.000 & 0.263 \\
\hline $\mathrm{BB}$ & 127 & 0.536 & 0.138 & 0.071 & 0.852 \\
\hline LMI - 2019 & 127 & 0.631 & 0.085 & 0.312 & 1.084 \\
\hline LMI - 2020 & 127 & 0.302 & 0.138 & -0.059 & 0.837 \\
\hline
\end{tabular}

Panel B. Liquidity risk measures

\begin{tabular}{|c|c|c|c|c|c|}
\hline & $(1)$ & $(2)$ & (3) & (4) & $(5)$ \\
\hline Liquidity Risk & $\begin{array}{c}-0.472 * * \\
(0.020)\end{array}$ & & & & \\
\hline Unused C\&I Loans / Assets & & $\begin{array}{c}-1.278 * * * \\
(0.002)\end{array}$ & & & \\
\hline $\mathrm{BB}$ & & & $\begin{array}{c}-0.385^{* *} \\
(0.022)\end{array}$ & & \\
\hline LMI - 2019 & & & & $\begin{array}{l}0.0782 \\
(0.761)\end{array}$ & \\
\hline LMI - 2020 & & & & & $\begin{array}{l}0.245^{*} \\
(0.076)\end{array}$ \\
\hline Controls & Yes & Yes & Yes & Yes & Yes \\
\hline R-squared & 0.359 & 0.386 & 0.356 & 0.322 & 0.343 \\
\hline Number obs. & 127 & 127 & 127 & 127 & 127 \\
\hline
\end{tabular}




\section{E. Pricing of drawdown options in credit line fees}

Do banks consider the deep out-of-the-money put option associated with aggregate drawdown risk when setting ex-ante price terms of credit lines? We follow earlier work on the pricing of credit lines such as Acharya et al. (2013) and Berg et al. (2015) and build a panel data set of U.S. non-financial firms that have obtained credit lines in the primary loan market over the 2010 to 2019 period. That is, using all originated loans from the Refinitiv Dealscan database, we keep only credit lines issued over the sample period, keep the lead arranger (following the procedures outlined in many previous papers) and collapse the All-In-Spread-Drawn (AISD) and the All-In-Spread-Undrawn (AISU) at their respective means to construct a firm-year-leadarranger level panel.

We then use the merged CRSP/Compustat database to add firm characteristics that affect a firm's cost of credit, in particular a firm's equity volatility as a measure of idiosyncratic risk and a firm's market beta for systematic risk. Other control variables include size, profitability, tangibility, Tobin's Q and leverage. We source bank characteristics from call report data including NPL/Loans, capital, non-interest income, bank size and bank profitability. Importantly, we obtain data on banks' aggregate risk exposure from call reports, CRSP and vlab including Bank Equity Beta (as a measure of systematic risk), LRMES (as a measure of downside risk), SRISK/Assets (as a measure of equity shortfall in times of a severe crisis) and Liquidity Risk (as a measure of aggregate drawdown risk). LIBOR is included as all contracts are floating rate and prior literature has shown that spreads and fees are sensitive to the current level of LIBOR.

We estimate the following regression:

$$
\operatorname{Cost}_{i, j, t}=\mu_{0}+\mu_{1} \text { AggRisk }_{j, t}+\mu_{3} \text { LIBOR }_{t}+\boldsymbol{\mu}_{\mathbf{4}} \boldsymbol{X}_{\boldsymbol{j}, \boldsymbol{t}}+\boldsymbol{\mu}_{\mathbf{5}} \boldsymbol{X}_{\boldsymbol{i}, \boldsymbol{t}}+\gamma_{t}+\lambda_{k}+\varepsilon_{i, j, t}
$$

Where AggRisk $_{j, t}$ are bank-specific aggregate risk proxies, $\boldsymbol{X}_{\boldsymbol{j}, \boldsymbol{t}}\left(\boldsymbol{X}_{\boldsymbol{i}, \boldsymbol{t}}\right)$ are bank (firm) characteristics, $\gamma_{t}$ are year and $\lambda_{k}$ industry fixed effects. 
The results are reported in Table E.1. We first show that idiosyncratic drawdown risk (measured using a firm's realized equity volatility over the past 12 months) and systematic drawdown risk (measured using a firm's stock beta) are priced in both commitment fee (AISU) and spread (AISD). This is consistent with, for example, Acharya et al. (2013) and Berg et al. (2015).

However, while a higher Bank Beta and LRMES both somewhat increase the price of credit lines, Liquidity Risk or Unused C\&I / Assets, on average, do not. Also, SRISK / Assets, which measures bank capital shortfall in times of aggregate market downturn, does not appear to be priced either. In other words, banks do not appear to be considering the deep out-of-themoney put option associated with aggregate drawdown risk when setting ex-ante price terms of credit lines. This may partly explain their need to fund aggregate drawdown risk with equity capital, as witnessed during the pandemic. 


\section{Table E.1. Pricing of drawdown options in credit line fees}

This table reports the results of OLS regressions of the All-In-Spread-Drawn (AISD) and the All-In-Spread-Undrawn (AISU) ratio on banks' aggregate risk exposures including Bank Equity Beta (as a measure of systematic risk), LRMES (as a measure of downside risk; LRMES is the Long Run Marginal Expected Shortfall, approximated in Acharya et al. (2012) as $1-\mathrm{e}^{\wedge}((-18 \times \mathrm{MES}))$, where MES is the one-day loss expected in bank i's return if market returns are less than -2\%), SRISK/Assets (as a measure of equity shortfall in times of a severe crisis) and Liquidity Risk (as a measure of aggregate drawdown risk and defined as Unused Commitments plus Wholesale Funding minus Liquidity (\% Assets)). We include them individually in regressions (2) to (5) and (7) to (10). All regressions include bank characteristics: NPL/Loans (Non-performing loans (\%Loans)), Capital (Equity/Assets), NonInterest Income (Non-interest-income (\%Operating revenues)), Bank Size (Log of Total Assets), Bank Profitability (Return on assets: Net Income / Assets). All regressions further include borrower characteristics: Equity Volatility (12-months firms equity volatility), Firm Equity Beta (12-month daily beta with the S\&P 500 return), Firm Size (Log of Total Assets; deflated using the U.S. PPI), Firm Profitability (EBITDA / Assets), Tangibility (Net PP\&E / Assets), Tobin's Q (Market Assets / Assets), Leverage ((LT Debt + ST Debt) / Market Assets). All regressions include the LIBOR as well as year and industry (2-digit) fixed effects. Standard errors are clustered at the firm level.

(continued on next page) 
(continued from previous page)

\begin{tabular}{|c|c|c|c|c|c|c|c|c|c|c|}
\hline & (1) & (2) & $\begin{array}{c}(3) \\
\text { AISD } \\
\end{array}$ & (4) & (5) & (6) & (7) & $\begin{array}{c}(8) \\
\text { AISU } \\
\end{array}$ & (9) & (10) \\
\hline Bank Equity Beta & & $\begin{array}{l}0.0582 \\
(0.147)\end{array}$ & & & & & $\begin{array}{c}0.0161 * * \\
(0.021)\end{array}$ & & & \\
\hline LRMES & & & $\begin{array}{c}1.293 * * \\
(0.039)\end{array}$ & & & & & $\begin{array}{c}0.187 * \\
(0.085)\end{array}$ & & \\
\hline SRISK / Assets & & & & $\begin{array}{c}1.772 \\
(0.293)\end{array}$ & & & & & $\begin{array}{c}0.255 \\
(0.382)\end{array}$ & \\
\hline Liquidity Risk & & & & & $\begin{array}{c}-0.330 \\
(0.185)\end{array}$ & & & & & $\begin{array}{r}-0.0253 \\
(0.581)\end{array}$ \\
\hline LIBOR & $\begin{array}{c}-0.288^{* * *} \\
(0.000)\end{array}$ & $\begin{array}{c}-0.278 * * * \\
(0.001)\end{array}$ & $\begin{array}{c}-0.243^{* * *} \\
(0.006)\end{array}$ & $\begin{array}{c}-0.272 * * * \\
(0.002)\end{array}$ & $\begin{array}{c}-0.311 * * * \\
(0.000)\end{array}$ & $\begin{array}{c}-0.0516^{* * *} \\
(0.000)\end{array}$ & $\begin{array}{c}-0.0488 * * * \\
(0.000)\end{array}$ & $\begin{array}{c}-0.0451 * * * \\
(0.002)\end{array}$ & $\begin{array}{c}-0.0492 * * * \\
(0.001)\end{array}$ & $\begin{array}{c}-0.0534 * * * \\
\quad(0.000)\end{array}$ \\
\hline \multicolumn{11}{|l|}{ Bank Characteristics } \\
\hline NPL / Loans & $\begin{array}{c}1.864 \\
(0.342)\end{array}$ & $\begin{array}{c}2.298 \\
(0.261)\end{array}$ & $\begin{array}{c}2.120 \\
(0.281)\end{array}$ & $\begin{array}{c}2.474 \\
(0.242)\end{array}$ & $\begin{array}{c}1.832 \\
(0.339)\end{array}$ & $\begin{array}{l}0.565^{*} \\
(0.072)\end{array}$ & $\begin{array}{c}0.684 * * \\
(0.032)\end{array}$ & $\begin{array}{l}0.602 * \\
(0.054)\end{array}$ & $\begin{array}{l}0.652^{*} \\
(0.053)\end{array}$ & $\begin{array}{l}0.562^{*} \\
(0.072)\end{array}$ \\
\hline Capital & $\begin{array}{c}-5.395 * * \\
(0.013)\end{array}$ & $\begin{array}{c}-4.925^{* *} \\
(0.018)\end{array}$ & $\begin{array}{c}-4.967 * * \\
(0.013)\end{array}$ & $\begin{array}{c}-4.981 * * \\
(0.020)\end{array}$ & $\begin{array}{c}-5.412 * * * \\
(0.009)\end{array}$ & $\begin{array}{l}-0.576 \\
(0.153)\end{array}$ & $\begin{array}{l}-0.446 \\
(0.246)\end{array}$ & $\begin{array}{l}-0.514 \\
(0.173)\end{array}$ & $\begin{array}{l}-0.516 \\
(0.198)\end{array}$ & $\begin{array}{l}-0.577 \\
(0.146)\end{array}$ \\
\hline Non-Interest Income & $\begin{array}{c}-0.0560 \\
(0.796)\end{array}$ & $\begin{array}{c}-0.0490 \\
(0.820)\end{array}$ & $\begin{array}{c}-0.171 \\
(0.458)\end{array}$ & $\begin{array}{c}-0.0628 \\
(0.773)\end{array}$ & $\begin{array}{c}-0.163 \\
(0.476)\end{array}$ & $\begin{array}{l}0.0103 \\
(0.795)\end{array}$ & $\begin{array}{l}0.0122 \\
(0.752)\end{array}$ & $\begin{array}{c}-0.00638 \\
(0.880)\end{array}$ & $\begin{array}{c}0.00930 \\
(0.815)\end{array}$ & $\begin{array}{c}0.00208 \\
(0.962)\end{array}$ \\
\hline Bank Size & $\begin{array}{c}-0.107 * * * \\
(0.001)\end{array}$ & $\begin{array}{c}-0.111^{* * * *} \\
(0.001)\end{array}$ & $\begin{array}{c}-0.110 * * * \\
(0.001)\end{array}$ & $\begin{array}{c}-0.119 * * * \\
(0.001)\end{array}$ & $\begin{array}{c}-0.126^{* * *} \\
(0.000)\end{array}$ & $\begin{array}{c}-0.0117^{* *} \\
(0.034)\end{array}$ & $\begin{array}{c}-0.0127^{* *} \\
(0.019)\end{array}$ & $\begin{array}{c}-0.0122 * * \\
(0.022)\end{array}$ & $\begin{array}{c}-0.0135^{* *} \\
(0.025)\end{array}$ & $\begin{array}{c}-0.0132 * * \\
(0.040)\end{array}$ \\
\hline Bank Profitability & $\begin{array}{c}-10.20^{* *} \\
(0.042)\end{array}$ & $\begin{array}{c}-8.032 \\
(0.113)\end{array}$ & $\begin{array}{c}0.132 \\
(0.984)\end{array}$ & $\begin{array}{c}-2.877 \\
(0.741)\end{array}$ & $\begin{array}{c}-10.47 * * \\
(0.036)\end{array}$ & $\begin{array}{c}-1.486^{*} \\
(0.077)\end{array}$ & $\begin{array}{c}-0.887 \\
(0.300)\end{array}$ & $\begin{array}{l}0.0100 \\
(0.993)\end{array}$ & $\begin{array}{l}-0.430 \\
(0.765)\end{array}$ & $\begin{array}{c}-1.507^{*} \\
(0.074)\end{array}$ \\
\hline \multicolumn{11}{|l|}{ Firm Characteristics } \\
\hline Equity Volatility & $\begin{array}{c}0.360^{* *} \\
(0.019)\end{array}$ & $\begin{array}{c}0.366^{* *} \\
(0.015)\end{array}$ & $\begin{array}{c}0.367^{* *} \\
(0.015)\end{array}$ & $\begin{array}{c}0.364^{* *} \\
(0.016)\end{array}$ & $\begin{array}{c}0.360^{* *} \\
(0.020)\end{array}$ & $\begin{array}{c}0.0700^{* * *} \\
(0.000)\end{array}$ & $\begin{array}{c}0.0716^{* * *} \\
(0.000)\end{array}$ & $\begin{array}{c}0.0709 * * * \\
(0.000)\end{array}$ & $\begin{array}{c}0.0706^{* * *} \\
(0.000)\end{array}$ & $\begin{array}{c}0.0700 * * * \\
(0.000)\end{array}$ \\
\hline Firm Equity Beta & $\begin{array}{c}0.175^{* * *} \\
(0.001)\end{array}$ & $\begin{array}{c}0.176^{* * * *} \\
(0.001)\end{array}$ & $\begin{array}{c}0.173 * * * \\
(0.001)\end{array}$ & $\begin{array}{c}0.174 * * * \\
(0.001)\end{array}$ & $\begin{array}{c}0.176^{* * * *} \\
(0.001)\end{array}$ & $\begin{array}{c}0.0482 * * * \\
(0.000)\end{array}$ & $\begin{array}{c}0.0485^{* * *} \\
(0.000)\end{array}$ & $\begin{array}{c}0.0480 * * * \\
(0.000)\end{array}$ & $\begin{array}{c}0.0480 * * * \\
(0.000)\end{array}$ & $\begin{array}{c}0.0482 * * * \\
(0.000)\end{array}$ \\
\hline Firm Size & $\begin{array}{c}-0.170 * * * \\
(0.000)\end{array}$ & $\begin{array}{c}-0.169 * * * \\
(0.000)\end{array}$ & $\begin{array}{c}-0.167 * * * \\
(0.000)\end{array}$ & $\begin{array}{c}-0.169 * * * \\
(0.000)\end{array}$ & $\begin{array}{c}-0.170 * * * \\
(0.000)\end{array}$ & $\begin{array}{c}-0.0326^{* * * *} \\
(0.000)\end{array}$ & $\begin{array}{c}-0.0324 * * * \\
(0.000)\end{array}$ & $\begin{array}{c}-0.0323 * * * \\
(0.000)\end{array}$ & $\begin{array}{c}-0.0325^{* * *} \\
(0.000)\end{array}$ & $\begin{array}{c}-0.0327 * * * \\
(0.000)\end{array}$ \\
\hline Firm Profitability & $\begin{array}{l}-0.200 \\
(0.327)\end{array}$ & $\begin{array}{c}-0.201 \\
(0.328)\end{array}$ & $\begin{array}{l}-0.193 \\
(0.345)\end{array}$ & $\begin{array}{l}-0.203 \\
(0.318)\end{array}$ & $\begin{array}{l}-0.211 \\
(0.290)\end{array}$ & $\begin{array}{l}0.0113 \\
(0.716)\end{array}$ & $\begin{array}{l}0.0110 \\
(0.725)\end{array}$ & $\begin{array}{l}0.0123 \\
(0.693)\end{array}$ & $\begin{array}{l}0.0108 \\
(0.726)\end{array}$ & $\begin{array}{l}0.0105 \\
(0.735)\end{array}$ \\
\hline Tangibility & $\begin{array}{c}-0.475^{* * *} \\
(0.000)\end{array}$ & $\begin{array}{c}-0.478 * * * \\
(0.000)\end{array}$ & $\begin{array}{c}-0.475^{* * *} \\
(0.000)\end{array}$ & $\begin{array}{c}-0.474 * * * \\
(0.000)\end{array}$ & $\begin{array}{c}-0.476^{* * *} \\
(0.000)\end{array}$ & $\begin{array}{c}-0.0904 * * * \\
(0.000)\end{array}$ & $\begin{array}{c}-0.0913 * * * \\
(0.000)\end{array}$ & $\begin{array}{c}-0.0905^{* * *} \\
(0.000)\end{array}$ & $\begin{array}{c}-0.0903 * * * \\
(0.000)\end{array}$ & $\begin{array}{c}-0.0905^{* * *} \\
(0.000)\end{array}$ \\
\hline Tobin's Q & $\begin{array}{c}-0.0279 * * \\
(0.040)\end{array}$ & $\begin{array}{c}-0.0281 * * \\
(0.038)\end{array}$ & $\begin{array}{c}-0.0274 * * \\
(0.042)\end{array}$ & $\begin{array}{c}-0.0275^{* *} \\
(0.042)\end{array}$ & $\begin{array}{c}-0.0265^{* *} \\
(0.049)\end{array}$ & $\begin{array}{c}-0.0103 * * * \\
(0.000)\end{array}$ & $\begin{array}{c}-0.0104 * * * \\
(0.000)\end{array}$ & $\begin{array}{c}-0.0103 * * * \\
(0.000)\end{array}$ & $\begin{array}{c}-0.0103 * * * \\
(0.000)\end{array}$ & $\begin{array}{c}-0.0102 * * * \\
(0.000)\end{array}$ \\
\hline Leverage & $\begin{array}{c}1.756 * * * \\
(0.000)\end{array}$ & $\begin{array}{c}1.753 * * * \\
(0.000)\end{array}$ & $\begin{array}{c}1.764 * * * \\
(0.000)\end{array}$ & $\begin{array}{c}1.755^{* * * *} \\
(0.000)\end{array}$ & $\begin{array}{c}1.757 * * * \\
(0.000)\end{array}$ & $\begin{array}{c}0.320 * * * \\
(0.000)\end{array}$ & $\begin{array}{c}0.319 * * * \\
(0.000)\end{array}$ & $\begin{array}{c}0.321 * * * \\
(0.000)\end{array}$ & $\begin{array}{c}0.320 * * * \\
(0.000)\end{array}$ & $\begin{array}{c}0.320 * * * \\
(0.000)\end{array}$ \\
\hline $\begin{array}{l}\text { Year Fixed Effect } \\
\text { Indury Fixed Fffect }\end{array}$ & Yes & Yes & Yes & Yes & Yes & Yes & Yes & Yes & Yes & Yes \\
\hline Industry Fixed EIrect & Yes & Yes & Yes & Yes & Yes & Yes & Yes & res & res & res \\
\hline $\begin{array}{l}\text { R-squared } \\
\text { Number obs. }\end{array}$ & $\begin{array}{l}0.463 \\
2657\end{array}$ & $\begin{array}{l}0.463 \\
2657\end{array}$ & $\begin{array}{l}0.464 \\
2657\end{array}$ & $\begin{array}{l}0.463 \\
2657\end{array}$ & $\begin{array}{l}0.463 \\
2657\end{array}$ & $\begin{array}{l}0.472 \\
2657\end{array}$ & $\begin{array}{l}0.473 \\
2657\end{array}$ & $\begin{array}{l}0.473 \\
2657\end{array}$ & $\begin{array}{l}0.472 \\
2657\end{array}$ & 0.472 \\
\hline
\end{tabular}

